\title{
New Scandium Borylimido Chemistry: Synthesis, Bonding, and Reactivity
}

\author{
Benjamin A. Clough, ${ }^{\dagger}$ Simona Mellino, ${ }^{\dagger}$ Eric Clot, ${ }^{*}+\underset{\ddagger}{\dagger}$ and Philip Mountford ${ }^{*},^{\dagger}$ \\ ${ }^{\dagger}$ Chemistry Research Laboratory, Department of Chemistry, University of Oxford, Mansfield Road, Oxford OX1 3TA, U.K. \\ ${ }^{\ddagger}$ Institut Charles Gerhardt Montpellier, UMR 5253 CNRS-UM-ENSCM, Université de Montpellier, cc 1501, Place Eugène Bataillon, \\ F-34095 Montpellier Cedex 5, France
}

Supporting Information

ABSTRACT: We report a combined synthetic, mechanistic, and theoretical study of the first borylimido complex of a rare earth metal, $\left(\mathrm{NacNac}^{\mathrm{NMe}_{2}}\right) \mathrm{Sc}\left\{\mathrm{NB}\left(\mathrm{NAr}{ }^{\prime} \mathrm{CH}\right)_{2}\right\}\left(\mathbf{2 5}, \mathrm{Ar}^{\prime}=2,6-\right.$ $\mathrm{C}_{6} \mathrm{H}_{3}{ }^{\mathrm{i}} \mathrm{Pr}_{2}, \mathrm{NacNac}^{\mathrm{NMe}_{2}}=\mathrm{Ar}^{\prime} \mathrm{NC}(\mathrm{Me}) \mathrm{CHC}(\mathrm{Me})$ $\left.\mathrm{NCH}_{2} \mathrm{CH}_{2} \mathrm{NMe}_{2}\right)$. Thermolysis of the methyl-borylamide $\left(\mathrm{NacNac}^{\mathrm{NMe}_{2}}\right) \mathrm{Sc}(\mathrm{Me})\left\{\mathrm{NHB}\left(\mathrm{NAr}^{\prime} \mathrm{CH}\right)_{2}\right\}(\mathbf{1 8})$ generated tran-
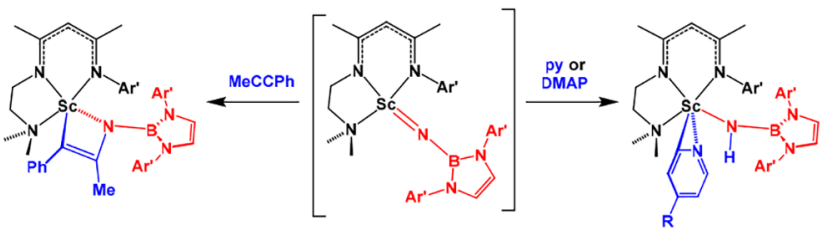
sient imide 25 via rate-determining, first-order methane elimination $(\mathrm{KIE} \approx 8.7)$. In the absence of external substrate, 25 underwent a reversible cyclometalation reaction $\left(\mathrm{sp}^{3} \mathrm{C}-\mathrm{H}\right.$ bond addition to $\left.\mathrm{Sc}=\mathrm{N}_{\text {imide }}\right)$ with a methyl group of the $\mathrm{NacNac}{ }^{\mathrm{NMe}_{2}}$ ligand forming $\left\{\mathrm{MeC}\left(\mathrm{NC}_{6} \mathrm{H}_{3}{ }^{\mathrm{i}} \mathrm{PrCH}(\mathrm{Me}) \mathrm{CH}_{2}\right) \mathrm{CHC}\right.$ $\left.(\mathrm{Me}) \mathrm{NCH}_{2} \mathrm{CH}_{2} \mathrm{NMe}_{2}\right\} \mathrm{Sc}\left\{\mathrm{NHB}\left(\mathrm{NAr}{ }^{\prime} \mathrm{CH}\right)_{2}\right\}$ (21). In the presence of pyridine or DMAP, reversible sp ${ }^{2} \mathrm{C}-\mathrm{H}$ bond activation occurred, forming orthometalated complexes $\left(\mathrm{NacNac}^{\mathrm{NMe}_{2}}\right) \mathrm{Sc}\left\{\mathrm{NHB}\left(\mathrm{NAr}{ }^{\prime} \mathrm{CH}\right)_{2}\right\}\left(\eta^{2}-4-\mathrm{NC}_{5} \mathrm{H}_{3} \mathrm{R}\right)(\mathrm{R}=\mathrm{H} \text { or } \mathrm{NMe})_{2}$. In situ reaction of 25 with $\mathrm{HCCT}$ ol gives irreversible sp $\mathrm{C}-\mathrm{H}$ bond activation under kinetic control, and with $\mathrm{MeCCPh}[2+2]$ cycloaddition to $\mathrm{Sc}=\mathrm{N}_{\text {imide }}$ takes place. These reactions represent the first substrate activation processes for any metal-bound borylimide. The bonding in $\mathbf{2 5}$ and the mechanism and thermodynamics of the reactions have been studied using density functional theory (DFT), supported by quantum theory of atoms in molecules and natural bond orbital analysis. Although the borylimido and arylimido dianions studied here are formally isoelectronic and possess comparable frontier molecular orbitals, the borylimido ligand is both a better $\pi$-donor and $\sigma$-donor, forming stronger and shorter metal-nitrogen bonds with somewhat reduced ionicity. Despite this, reactions of these types of borylimides with $\mathrm{C}-\mathrm{H}$ or $\mathrm{C} \equiv \mathrm{C}$ bonds are all more exothermic and more strongly activating than for the corresponding arylimides. DFT calculations on model systems of differing steric bulk unpicked the underlying thermodynamic factors controlling the reactions of $\mathbf{2 5}$ and its reaction partners, and a detailed comparison was made with the previously described arylimido homologues.

\section{INTRODUCTION}

Transition metal terminal organoimido complexes of the type $(\mathrm{L}) \mathrm{M}=\mathrm{NR}(\mathrm{R}=$ alkyl or aryl; $\mathrm{L}=$ supporting ligand or ligand set) have given rise to a wealth of new chemistry over the past three decades. ${ }^{1}$ Most of this interest has been centered around the activation and/or transformations of unsaturated or saturated substrates at the polar metal-nitrogen multiple bond itself (usually described as a $\sigma^{2} \pi^{4}$ triple bond), mostly for early transition metal complexes of Groups 4 and 5. ${ }^{2}$ The most notable exceptions to this general observation are the Schrock olefin metathesis catalyst families in which arylimido groups act as spectator ligands, ${ }^{3}$ but also other examples are certain types of Ziegler-type olefin polymerization and ring-opening metathesis polymerization catalysts. ${ }^{4}$

Compared with their Group 4 counterparts, well-established terminal organoimido complexes of the rare earth metals ( $\mathrm{Ln}$, defined as Group 3 and the lanthanides) are considerably more scarce, ${ }^{1 \mathrm{~d}, \mathrm{f}}$ and their successful synthesis, isolation, and structural characterization was only achieved within the past 7 years, first by Chen et al. (1, Figure 1). ${ }^{5}$ Prior to this, the field was limited to dimeric complexes (for example, Hessen's 2, Figure $1^{6}$ ) or higher-nuclearity clusters which contain bridging $\mu$-imido ligands, because of the more ionic nature and larger radii of these metals. ${ }^{1 \mathrm{~d}}$ Even now, almost all of the isolated rare earth imido complexes are either for scandium (e.g., Piers's 3 (Figure $1)^{7}$ or Cui's $\left\{\mathrm{N}\left(\mathrm{PPh}_{2} \mathrm{NPh}\right)_{2}\right\} \mathrm{Sc}\left(\mathrm{NAr}^{\prime}\right)(\mathrm{DMAP})_{2}\left(\mathrm{Ar}^{\prime}=2,6-\right.$ $\left.\left.\mathrm{C}_{6} \mathrm{H}_{3}{ }^{\mathrm{i}} \mathrm{Pr}_{2}\right)\right)^{8}$ or other small metals (e.g., in Anwander's $4(\mathrm{M}=$ $\mathrm{Y}, \mathrm{Lu})),{ }^{9}$ featuring ligands with pronounced steric profiles. Very recently, Schelter et al. reported a potassium-capped cerium(4+) imide. ${ }^{10}$

Although Chen's ( $\left.\mathrm{NacNac}^{\mathrm{NMe}_{2}}\right) \mathrm{Sc}\left(\mathrm{NAr}^{\prime}\right)$ (DMAP) (1, Nac$\left.\left.\mathrm{Nac}^{\mathrm{NMe}_{2}}=\left(\mathrm{Ar}^{\prime}\right) \mathrm{NC}(\mathrm{Me}) \mathrm{CHC}(\mathrm{Me}) \mathrm{NCH}_{2} \mathrm{CH}_{2} \mathrm{NMe}_{2}\right)\right)$ was the first isolated rare earth, terminal imide, evidence of the high propensity to reactivity of the $\mathrm{Ln}=\mathrm{NR}$ moiety was provided by Mindiola et al.'s transient imide (PNP)Sc $\left(\mathrm{NAr}^{\prime}\right)(\mathrm{PNP}=\mathrm{N}\{2$ $\left.\mathrm{P}^{\mathrm{i}} \mathrm{Pr}_{2}-4-\mathrm{C}_{6} \mathrm{H}_{3} \mathrm{Me}\right\}_{2}$ ) generated in situ from (PNP)Sc(Me)(NHAr') by methane elimination. ${ }^{11}$ This compound activates the ortho $\mathrm{C}-\mathrm{H}$ bonds of various pyridines $\mathrm{py}^{\mathrm{R}}$ via putative adducts of the type (PNP) $\mathrm{Sc}\left(\mathrm{NAr}^{\prime}\right)\left(\mathrm{py}^{\mathrm{R}}\right)$, ultimately giving an atom-economical route to substituted pyridines. ${ }^{12}$ Nonetheless, with isolated $\mathbf{1}$ in hand, along with a DMAP-free homologue

Received: May 25, 2017

Published: July 13, 2017 

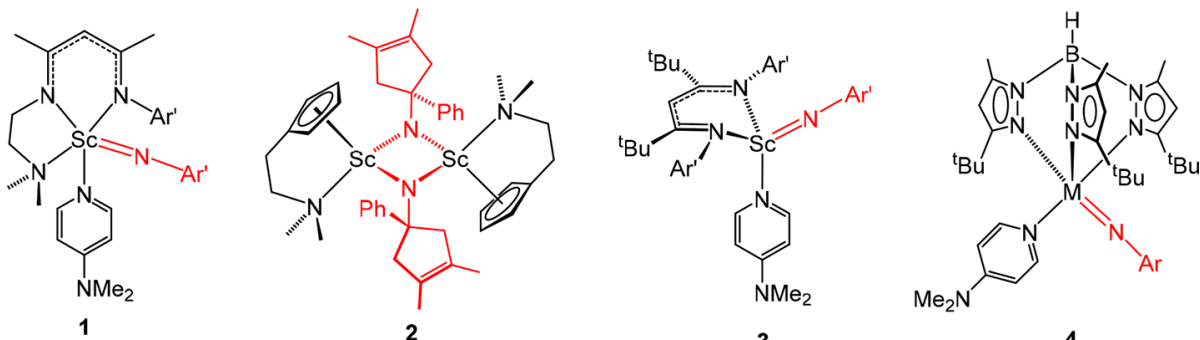

3

4

Figure 1. Selected bridging and terminal rare earth imido complexes $\left(\mathrm{Ar}^{\prime}=2,6-\mathrm{C}_{6} \mathrm{H}_{3}{ }^{\mathrm{i}} \mathrm{Pr}_{2}\right)^{5-7,9}$
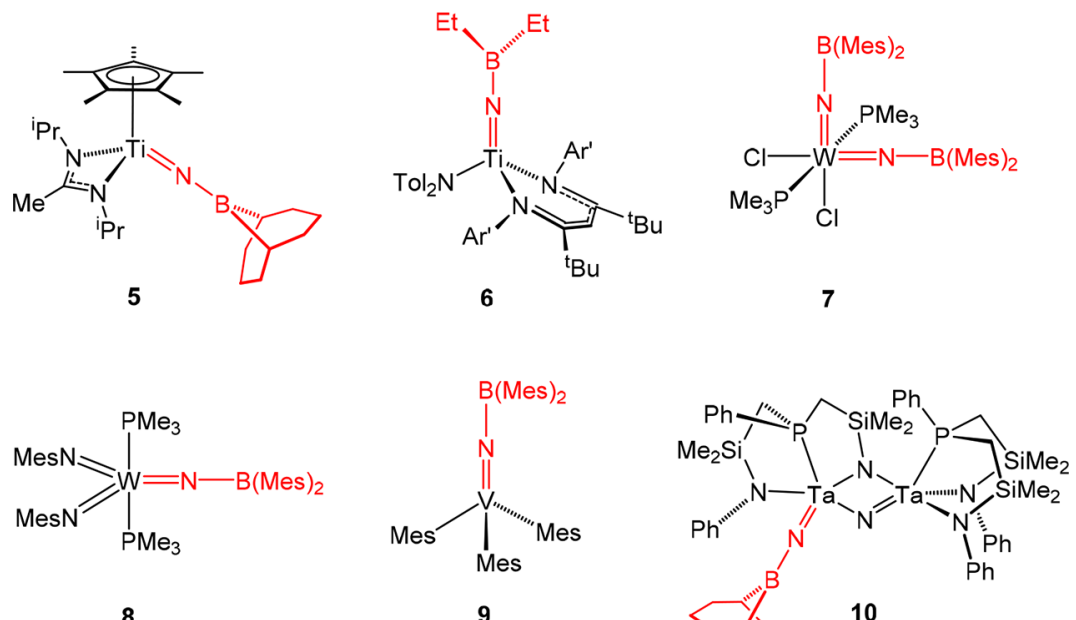

8

9

10

Figure 2. Some previously reported terminal borylimido complexes. ${ }^{15 a, 16-19}$

featuring a tetradentate version of $\mathrm{NacNac}^{\mathrm{NMe}_{2}}{ }^{13}$ Chen et al. have been able to quite comprehensively map out the reactivity of the $\mathrm{Sc}=\mathrm{NAr}$ functional group with $\mathrm{E}-\mathrm{H}(\mathrm{E}=\mathrm{C}, \mathrm{B}, \mathrm{H})$ and other saturated bonds, and polar and nonpolar unsaturated substrates. A fairly clear picture of the similarities and differences between $\mathrm{Sc}_{\mathrm{c}}=\mathrm{NAr}^{\prime}$ and the more widely studied Group 4 organoimido counterparts is starting to emerge.

Our group has been interested in developing early transition metal-imido and related metal-ligand multiple bond chemistry, ${ }^{2 a, b, d, 4 b, 14}$ and during the course of these studies we recently reported the serendipitous formation of a very rare ${ }^{15}$ titanium borylimido compound 5 (Figure 2$)^{16}$ through the reductive $\mathrm{N}-\mathrm{N}$ bond cleavage reaction of the hydrazide $\mathrm{Cp}{ }^{*} \mathrm{Ti}\{\mathrm{MeC}-$ $\left.\left(\mathrm{N}^{\mathrm{i} P r}\right)_{2}\right\}\left(\mathrm{NNR}_{2}\right)(\mathrm{R}=\mathrm{Me}$ or $\mathrm{Ph})$ with 9-BBN. Prior to this, the only other terminal Group 4 borylimide known was Mindiola's 6, formed from the parent imide (i.e., terminal $\mathrm{NH}$ ) with 2 equiv of $\mathrm{NaHBEt}_{3}$. ${ }^{15 a}$ Borylimides of Groups 5 and 6 are also rare (Figure 2). Wilkinson reported the first borylimido complex of any transition metal $(7)^{17}$ by the oxidative addition reaction of $\mathrm{WCl}_{2}\left(\mathrm{PMe}_{3}\right)_{4}$ with 2 equiv of $\mathrm{Mes}_{2} \mathrm{BN}_{3}$; comparable routes were used to form 8 and 9 from $\mathrm{W}(4+)$ and $\mathrm{V}(3+)$ precursors, respectively. ${ }^{18}$ Dinitrogen ligand $\mathrm{N}-\mathrm{N}$ bond cleavage reactions with boranes have also given dinuclear borylimido derivatives, including Fryzuk's 10. ${ }^{19}$

To date there have been no reports of the reactivity of any transition metal borylimido complex with small molecules. Elegant work by Bettinger et al. since $2006,{ }^{20}$ as well as an earlier report from Paetzold, ${ }^{21}$ has shown that heteroatomstabilized borylnitrenes such as $\mathrm{NB}\left(\mathrm{N}^{\mathrm{i}} \mathrm{Pr}_{2}\right)_{2}$, and, in particular, NBCat $\left(\right.$ Cat $\left.=1,2-\mathrm{O}_{2} \mathrm{C}_{6} \mathrm{H}_{4}\right)$ can be photochemically generated from the corresponding azides $\mathrm{X}_{2} \mathrm{BN}_{3}$, trapped in frozen argon matrices, and shown to undergo coupling reactions with $\mathrm{CO}$ and $\mathrm{N}_{2}$ and insertion reactions into $\mathrm{C}-\mathrm{H}, \mathrm{B}-\mathrm{H}, \mathrm{H}-\mathrm{H}$, and $\mathrm{B}-$ $\mathrm{N}$ bonds. ${ }^{20,22}$ Computational studies of the hypothetical 20valence-electron $(\mathrm{CO})_{4} \mathrm{FeNBCat}$ and $(\mathrm{CO})_{4} \mathrm{FeNBH}_{2}$ were also reported, with $\mathrm{NBCat}$ being found to be a better 4-electron donor to the iron center than $\mathrm{BNH}_{2}$ because $2 \mathrm{p} \pi(\mathrm{O}) \rightarrow 2 \mathrm{p} \pi(\mathrm{B})$ donation reduces the boron atom's $\pi$-acidity with respect to the nitrogen atom's lone pair. ${ }^{2 a}$

Given the current interest and novelty of rare earth organoimido compounds, and the absence of any borylimido complexes of these metals, or reactivity studies of any metalbound $\mathrm{NBX}_{2}$ moiety, we were interested to develop new scandium borylimido chemistry. None of the previously reported routes to borylimides (i.e., hydrazido $\mathrm{N}-\mathrm{N}$ bond cleavage, oxidative addition to lower oxidation state precursors, transformation of a parent imide) are suitable for these metals because either the necessary starting material does not yet exist (Group 3 terminal hydrazide or parent imide), or are rather rare ( $1+$ oxidation state), and so we report new, alternative routes based on hydrocarbon elimination protocols. In addition, building on Bettinger's initial bonding analysis of the hypothetical 20-valence-electron $(\mathrm{CO})_{4} \mathrm{FeNBCat}$ and (CO) ${ }_{4} \mathrm{FeNBH}_{2}$ compounds, we describe a molecular orbital and quantum theory of atoms in molecules (QTAIM) study of scandium aryl- and boryl-imido complexes as well as comparative combined experimental and computational studies of the $\mathrm{C}-\mathrm{H}$ bond activation and alkyne coupling reactions of these types of imido complex. 


\section{RESULTS AND DISCUSSION}

Entry Points to Scandium Borylimido Chemistry. Given that Chen et al. have already demonstrated the effectiveness of donor-functionalized "NacNac"-type ligands, namely $\mathrm{NacNac}^{\mathrm{NMe}_{2}}$ (cf. 1 in Figure 1) and a tetradentate homologue $\mathrm{MeC}\left(\mathrm{NAr}^{\prime}\right) \mathrm{CHC}(\mathrm{Me}) \mathrm{NCH}_{2} \mathrm{CH}_{2} \mathrm{~N}(\mathrm{Me})$ $\mathrm{CH}_{2} \mathrm{CH}_{2} \mathrm{NMe}_{2}$, in accessing new scandium arylimido chemistry we chose to use these same supporting platforms. Likewise, drawing upon Bettinger's suggestion ${ }^{22 \mathrm{a}}$ that heteroatomfunctionalized $\mathrm{NBX}_{2}(\mathrm{X}=$ heteroatom group) moieties may be better overall donors than their $\mathrm{NBR}_{2}(\mathrm{R}=\sigma$-only group $)$ analogues we targeted the two borylamines $\mathrm{H}_{2} \mathrm{NB}\left(\mathrm{N}^{\mathrm{i} P r}\right)_{2} \mathrm{C}_{6} \mathrm{H}_{4}$ (11) and $\mathrm{H}_{2} \mathrm{NB}\left(\mathrm{NAr}^{\prime} \mathrm{CH}\right)_{2}\left(12, \mathrm{Ar}^{\prime}=2,6-\mathrm{C}_{6} \mathrm{H}_{3}{ }^{\mathrm{i}} \mathrm{Pr}_{2}\right)^{23}$ as entry points to scandium borylimido chemistry. We reasoned that a borylimido ligand of the type $\mathrm{NB}\left(\mathrm{N}^{\mathrm{i}} \mathrm{Pr}\right)_{2} \mathrm{C}_{6} \mathrm{H}_{4}$ formally derived from 11 would be sterically and electronically similar to the $\mathrm{NAr}^{\prime}$ moieties used in the work of Chen, Mindiola, Piers, and others, and also related to Bettinger's reactive NBCat (we did not target $\mathrm{H}_{2} \mathrm{NBC}$ at itself because of the poor steric protection offered by the $1,2-\mathrm{O}_{2} \mathrm{C}_{6} \mathrm{H}_{4}$ moiety). Borylamine 12 , with its large flanking $\mathrm{N}-\mathrm{Ar}^{\prime}$ groups provides even greater steric protection than the $\mathrm{N}-{ }^{\mathrm{i}} \operatorname{Pr}$ substituents of 11 . DFT studies of model compounds found that there was no significant electronic effect on $\mathrm{Sc}=\mathrm{NBX}_{2}$ bonding upon replacing the 1,2- $\mathrm{C}_{6} \mathrm{H}_{4}$ moiety in 11 (chosen for synthetic expedience) with the simple $1,2-\mathrm{C}_{2} \mathrm{H}_{2}$ linkage in $\mathbf{1 2}$.<smiles>CCCN1B(N)N(C(C)C)c2ccccc21</smiles>

11

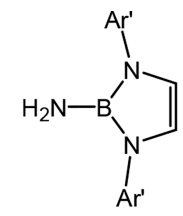

12
Our initial attempts to access a scandium borylimide focused on $\mathrm{H}_{2} \mathrm{NB}\left(\mathrm{N}^{\mathrm{i}} \mathrm{Pr}\right)_{2} \mathrm{C}_{6} \mathrm{H}_{4}(\mathbf{1 1})$ as described fully in the Supporting
Information (SI). Reaction of $\left(\mathrm{NacNac}^{\mathrm{NMe}_{2}}\right) \mathrm{ScCl}_{2}$ (13) with 2 equiv of $\mathrm{MeLi}$ in THF, based on previous protocols, ${ }^{5}$ formed $\left(\mathrm{NacNac}^{\mathrm{NMe}_{2}}\right) \mathrm{ScMe}_{2}$ (14). In situ reaction of 14 with 1 and 2 equiv of 11 produced the methyl-borylamide $\left(\mathrm{NacNac}^{\mathrm{NMe}_{2}}\right) \mathrm{Sc}$ (Me) $\left\{\mathrm{NHB}\left(\mathrm{N}^{\mathrm{i}} \mathrm{Pr}\right)_{2} \mathrm{C}_{6} \mathrm{H}_{4}\right\} \quad$ (15) and the bis(borylamide) $\left(\mathrm{NacNac}^{\mathrm{NMe}_{2}}\right) \mathrm{Sc}\left\{\mathrm{NHB}\left(\mathrm{N}^{\mathrm{i} P r}\right)_{2} \mathrm{C}_{6} \mathrm{H}_{4}\right\}_{2}$ (16), respectively. Thermolytic alkane elimination from primary amido-alkyl compounds is a well-established protocol for the synthesis of imido compounds for both the rare earths (vide supra) and the early transition metals. ${ }^{1 \mathrm{a}, \mathrm{b}, 2 \mathrm{a}, \mathrm{c}}$ Disappointingly, thermolysis reactions of 15 and 16 on the NMR tube scale formed complex mixtures of unidentified products. In a reaction on the preparative scale, although no single product could be properly isolated, some diffraction-quality crystals of $\left[\left\{\mathrm{MeC}\left(\mathrm{NAr}^{\prime}\right) \mathrm{CHC}\left(\mathrm{CH}_{2}\right)\right.\right.$ $\left.\left.\mathrm{NCH}_{2} \mathrm{CH}_{2} \mathrm{NMe}_{2}\right\} \mathrm{Sc}\left\{\mathrm{NHB}\left(\mathrm{N}^{\mathrm{i}} \mathrm{Pr}\right)_{2} \mathrm{C}_{6} \mathrm{H}_{4}\right\}\right]_{2} \quad$ (17) were obtained. This is a dimeric complex formed by intermolecular $\mathrm{C}-\mathrm{H}$ bond activation of the methyl group at the $\beta$-position of the NacNac ligand by a second scandium center (see Figure S2 of the SI).

In an attempt to direct the reactivity of these borylamido systems we turned to the more sterically encumbering borylamine $\mathrm{H}_{2} \mathrm{NB}\left(\mathrm{NAr}^{\prime} \mathrm{CH}\right)_{2} \quad(12) .^{23}$ Reaction of $\left(\mathrm{NacNac}^{\mathrm{NMe}_{2}}\right) \mathrm{ScMe}_{2}$ (14) with 1 equiv of $\mathrm{H}_{2} \mathrm{NB}\left(\mathrm{NAr}{ }^{\prime} \mathrm{CH}\right)_{2}$ (12) for $60 \mathrm{~h}$ at room temperature gave the methyl-borylamide $\left(\mathrm{NacNac}^{\mathrm{NMe}_{2}}\right) \mathrm{Sc}(\mathrm{Me})\left\{\mathrm{NHB}\left(\mathrm{NAr}{ }^{\prime} \mathrm{CH}\right)_{2}\right\} \quad$ (18) which was isolated as an off-white powder in $53 \%$ yield (Scheme 1 ). This reaction time is significantly longer than that required for quantitative formation of $\mathbf{1 5}$ and Chen's $\left(\mathrm{NacNac}^{\mathrm{NMe}_{2}}\right) \mathrm{Sc}$ $(\mathrm{Me})\left(\mathrm{NHAr}^{\prime}\right)$ (19) (16 and $24 \mathrm{~h}$ at room temperature, respectively), ${ }^{5}$ which may reflect the likely steric hindrance in the approach of the bulkier borylamine to the scandium center. When followed by ${ }^{1} \mathrm{H}$ NMR spectroscopy on the NMR tube scale, the formation of $\mathbf{1 8}$ was quantitative, and $\mathrm{CH}_{4}$ evolution was observed (signal at $0.16 \mathrm{ppm}$ ). The ${ }^{1} \mathrm{H}$ NMR spectrum of 18 displays an $\mathrm{Sc}-\mathrm{Me}$ resonance at $-0.90 \mathrm{ppm}$ and a broad $\mathrm{NH}$ singlet at $3.90 \mathrm{ppm}$. The ${ }^{11} \mathrm{~B}$ resonance of the borylamido ligand is $23.3 \mathrm{ppm}$.

Scheme 1. Synthesis of $\left(\mathrm{NacNac}^{\mathrm{NMe}_{2}}\right) \mathrm{Sc}(\mathrm{X})\left\{\mathrm{NHB}\left(\mathrm{NAr}^{\prime} \mathrm{CH}\right)_{2}\right\}(\mathrm{X}=\mathrm{Me}(18)$ or Cl (20))<smiles></smiles>

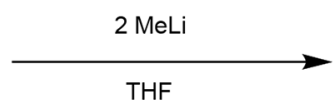

13

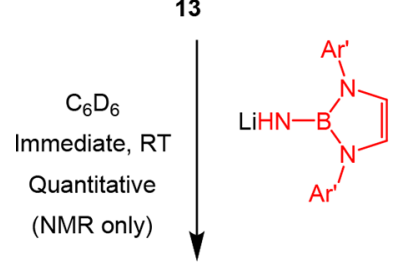

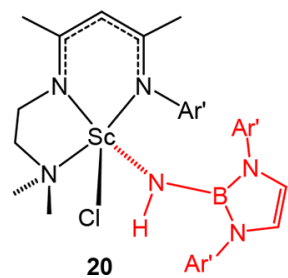<smiles></smiles>

14<smiles>NB1N([Al])C=CN1[Al]</smiles>

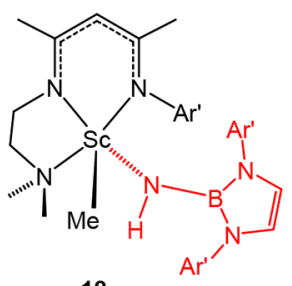

18 
Diffraction-quality crystals of $\mathbf{1 8}$ were grown from a benzene solution at room temperature. The solid-state structure is shown in Figure 3, along with key bond distances and angles.

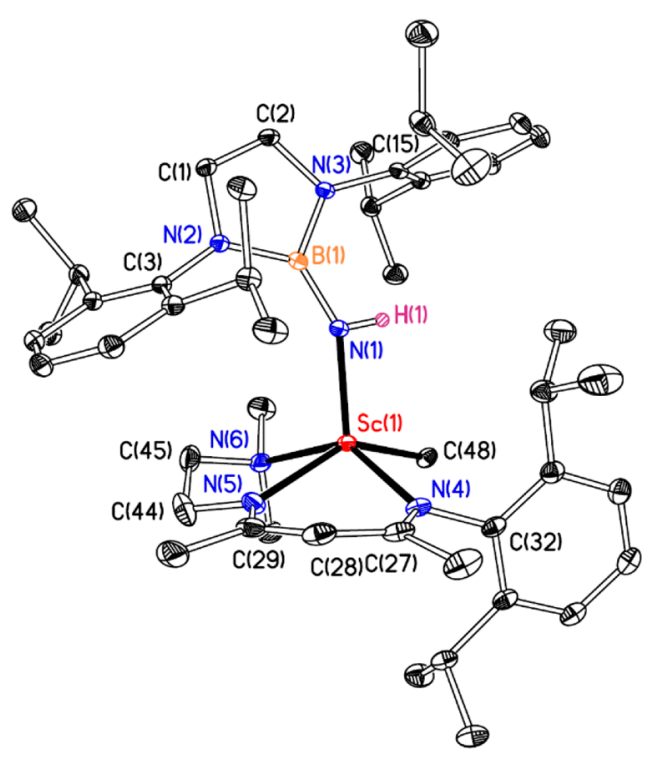

Figure 3. Displacement ellipsoid plot (20\% probability) of $\left(\mathrm{NacNac}^{\mathrm{NMe}_{2}}\right) \mathrm{Sc}(\mathrm{Me})\left\{\mathrm{NHB}\left(\mathrm{NAr}{ }^{\prime} \mathrm{CH}\right)_{2}\right\} \quad$ (18). C-bound $\mathrm{H}$ atoms omitted. $\mathrm{H}(1)$ is drawn as a sphere of arbitrary radius. Selected bond distances $(\AA)$ and angles (deg): $\mathrm{Sc}(1)-\mathrm{N}(1) 2.0629(8), \mathrm{Sc}(1)-\mathrm{C}(48)$ 2.2730(10), N(1)-B(1) 1.4179(13), N(1)-H(1) 0.821(17), Sc(1)$\mathrm{N}(1)-\mathrm{B}(1) 152.36(7)(\tau=0.02)$.

Complex 18 has a monomeric, five-coordinate structure with square-based pyramidal geometry (the Addison $\tau$ value being $0.02),{ }^{24}$ in which $\mathrm{N}(1)$ of the borylamido ligand resides in the apical position. The $\mathrm{Sc}(1)-\mathrm{N}(1)$ bond distance of $2.0629(8) \AA$ is slightly longer by $0.016(3) \AA$ than the corresponding one in the anilide $\left(\mathrm{NacNac}^{\mathrm{NMe}_{2}}\right) \mathrm{Sc}(\mathrm{Me})\left(\mathrm{NHAr}^{\prime}\right)(19,2.047(3) \AA)$, and the $\mathrm{Sc}(1)-\mathrm{C}(1)$ bond length of 2.273(1) A for the methyl ligand is also longer than that in $19(2.221(4) \AA)^{5}$ This probably reflects steric effects from the large boryl moiety.

Additionally, while we prepared a borylamide chloride analogue of 18, $\left(\mathrm{NacNac}^{\mathrm{NMe}_{2}}\right) \mathrm{Sc}(\mathrm{Cl})\left\{\mathrm{NHB}\left(\mathrm{NAr}{ }^{\prime} \mathrm{CH}\right)_{2}\right\}$ (20), through reaction of $\left(\mathrm{NacNac}^{\mathrm{NMe}_{2}}\right) \mathrm{ScCl}_{2}$ (13) with 1 equiv of the lithium borylamide $\mathrm{LiNHB}\left(\mathrm{NAr}^{\prime} \mathrm{CH}\right)_{2}$ on the NMR tube scale (Scheme 1), we were unable to convert it into a borylimido complex in situ. Full details are provided in the SI. Other attempts, all ultimately unproductive, to enter borylimido compounds through the use of $\mathrm{CH}_{2} \mathrm{SiMe}_{3}$ or $\mathrm{CH}_{2} \mathrm{CMe}_{3}$ groups are described in the SI, along with additional experiments using a tetradentate version of $\mathrm{NacNac}^{\mathrm{NMe}_{2}}$.

Thermolysis Reactions of ( $\left.\mathrm{NacNac}{ }^{\mathrm{NMe}_{2}}\right) \mathrm{Sc}(\mathrm{Me})\{\mathrm{NHB}-$ $\left(\mathrm{NAr}^{\prime} \mathrm{CH}\right)_{2}$ \} (18). With and without Lewis Bases. Thermolysis screening reactions of $\mathbf{1 8}$ were performed on the NMR tube scale in $\mathrm{C}_{6} \mathrm{D}_{6}$, both in the presence of 1 equiv of pyridine or DMAP, as well as without a Lewis base. After $\sim 16 \mathrm{~h}$ at $60{ }^{\circ} \mathrm{C}$, each reaction gave quantitative conversion to a different new species, together with the evolution of methane. The three products were each isolated on the preparative scale (Scheme 2).

For the base-free thermolysis, a toluene solution of $\mathbf{1 8}$ was heated at $60{ }^{\circ} \mathrm{C}$ for $16 \mathrm{~h}$. After workup, the product $\left\{\mathrm{MeC}\left(\mathrm{NC}_{6} \mathrm{H}_{3}{ }^{\mathrm{i}} \mathrm{PrCH}(\mathrm{Me}) \mathrm{CH}_{2}\right) \mathrm{CHC}(\mathrm{Me}) \mathrm{NCH}_{2} \mathrm{CH}_{2} \mathrm{NMe}_{2}\right\}-$ $\mathrm{Sc}\left\{\mathrm{NHB}\left(\mathrm{NAr}^{\prime} \mathrm{CH}\right)_{2}\right\}(\mathbf{2 1})$ was isolated as an off-white powder in $52 \%$ yield. The ${ }^{1} \mathrm{H}$ and ${ }^{13} \mathrm{C}$ NMR spectra and solid-state structure established $\mathbf{2 1}$ as a cyclometalated borylamide in which an isopropyl methyl group of the supporting $\mathrm{NacNac}{ }^{\mathrm{NMe} 2}$ ligand has undergone intramolecular $\mathrm{C}-\mathrm{H}$ activation at the metal center. The borylamide $\mathrm{N} \underline{\mathrm{H}}$ is found

Scheme 2. Synthesis of $\left\{\mathrm{MeC}\left(\mathrm{NC}_{6} \mathrm{H}_{3}{ }^{\mathrm{i}} \mathrm{PrCH}(\mathrm{Me}) \mathrm{CH}_{2}\right) \mathrm{CHC}(\mathrm{Me}) \mathrm{NCH}_{2} \mathrm{CH}_{2} \mathrm{NMe}_{2}\right\} \mathrm{Sc}\left\{\mathrm{NHB}\left(\mathrm{NAr}{ }^{\prime} \mathrm{CH}\right)_{2}\right\}$ (21) and $\left(\mathrm{NacNac}^{\mathrm{NMe}_{2}}\right) \mathrm{Sc}\left\{\mathrm{NHB}\left(\mathrm{NAr}{ }^{\prime} \mathrm{CH}\right)_{2}\right\}\left(\eta^{2}-4-\mathrm{NC}_{5} \mathrm{H}_{3} \mathrm{R}\right)\left(\mathrm{R}=\mathrm{H}(23)\right.$, or $\left.\mathrm{NMe}_{2}(24)\right)$

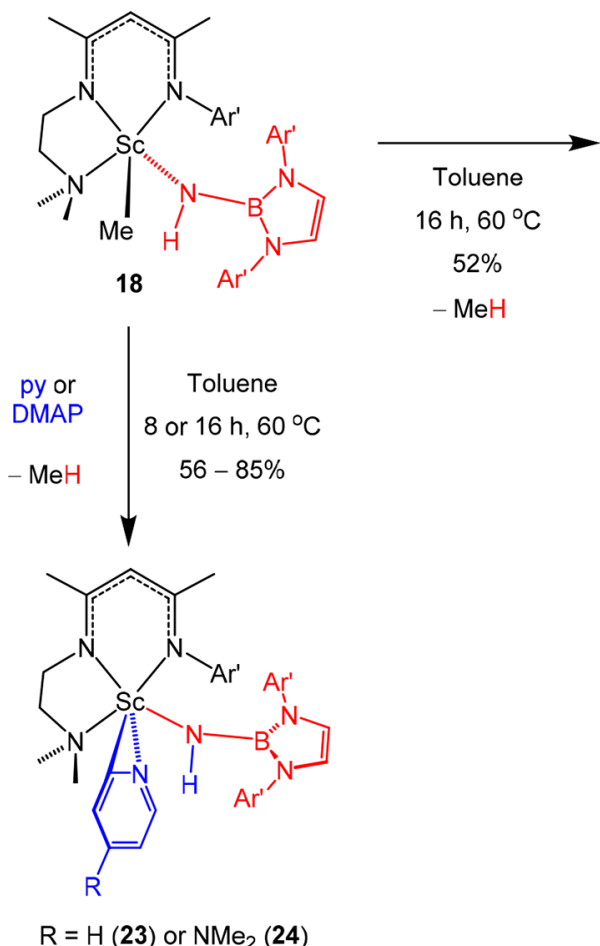

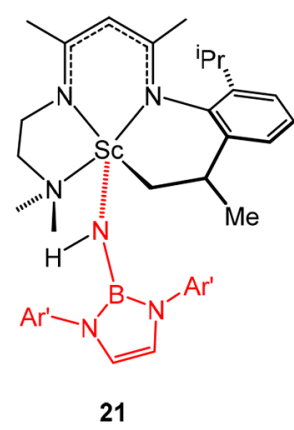

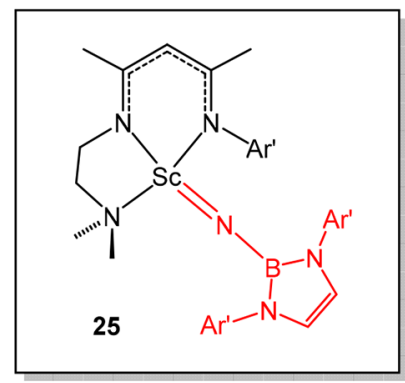

Proposed intermediate 
as a broad singlet at $2.83 \mathrm{ppm}$ in the ${ }^{1} \mathrm{H}$ NMR spectrum, and the diastereotopic hydrogens of the metalated methylene group $\left(\mathrm{ScCH}_{2}\right)$ appear as an apparent triplet (intensity $\left.1 \mathrm{H}\right)$ at 0.22 $\mathrm{ppm}$ and a doublet of doublets (intensity $1 \mathrm{H}$ ) at $-0.01 \mathrm{ppm}$ due to vicinal coupling to the adjacent methine ( $\mathrm{CHMe}$ ) in addition to geminal coupling. The Sc-bound carbon atom gives a ${ }^{13} \mathrm{C}$ signal at $32.0 \mathrm{ppm}$, and the ${ }^{11} \mathrm{~B}$ NMR spectrum shows a signal at $23.3 \mathrm{ppm}$.

Diffraction-quality crystals of $\mathbf{2 1}$ were grown from a benzene solution at room temperature. The solid-state structure is shown in Figure 4, along with key bond distances and angles.

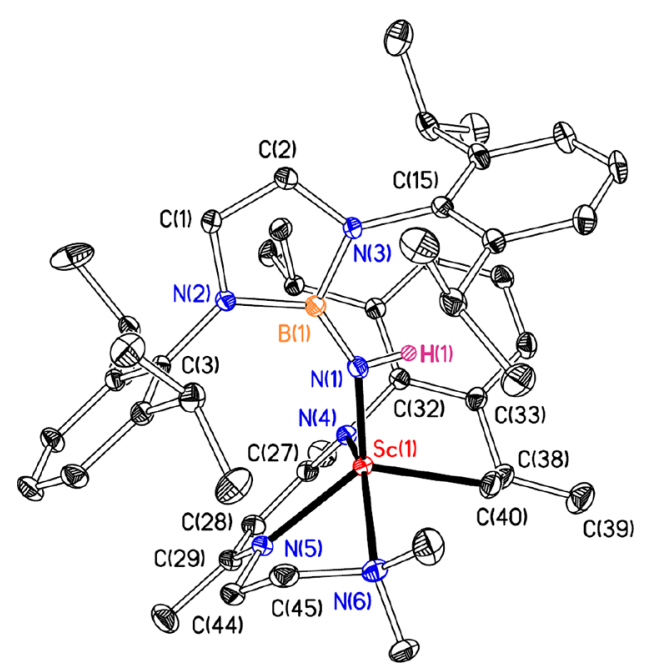

Figure 4. Displacement ellipsoid plot (20\% probability) of $\{\mathrm{MeC}$ $\left.\left(\mathrm{NC}_{6} \mathrm{H}_{3}{ }^{\mathrm{i}} \mathrm{PrCH}(\mathrm{Me}) \mathrm{CH}_{2}\right) \mathrm{CHC}(\mathrm{Me}) \mathrm{NCH}_{2} \mathrm{CH}_{2} \mathrm{NMe}_{2}\right\} \mathrm{Sc}\{\mathrm{NHB}-$ $\left.\left(\mathrm{NAr}{ }^{\prime} \mathrm{CH}\right)_{2}\right\}$ (21). C-bound $\mathrm{H}$ atoms omitted. $\mathrm{H}(1)$ is drawn as a sphere of arbitrary radius. Selected bond distances $(\AA)$ and angles (deg): $\mathrm{Sc}(1)-\mathrm{N}(1) 2.0609(18)$ [2.0649(18)], Sc(1)-C(40) 2.249(2) $[2.247(2)], \mathrm{N}(1)-\mathrm{B}(1) \quad 1.412(3) \quad[1.416(3)], \mathrm{N}(1)-\mathrm{H}(1) \quad 0.85(3)$ [0.91(3)], $\mathrm{Sc}(1)-\mathrm{N}(1)-\mathrm{B}(1)$ 153.96(15) [154.73(16)]. Values in brackets are for the second crystallographically independent molecule $(\tau=0.35[0.37])$

Complex 21 possesses a distorted square-based pyramidal geometry ( $\tau=0.35$ and 0.37 for the two crystallographically independent molecules) and is similar to that of $\mathbf{1 8}$ in which one vertex of the basal plane is now a cyclometalated methylene carbon (C(40)). This forms a new six-membered metallacycle with a distorted boat conformation. The borylamide group is again positioned at the apical site of the square pyramid. The average $\mathrm{Sc}(1)-\mathrm{N}(1)$ bond length of 2.063(3) $\AA$ is the same as that in $18(2.0629(8) \AA)$. The average $\mathrm{Sc}(1)-\mathrm{C}(40)$ distance of 2.248(2) A is slightly shorter than for the Sc-Me bond in $\mathbf{1 8}$ (2.2730(10) $\AA$ ) which may be due to the chelating nature of this moiety. 21 is the analogue of Chen's anilide $\{\mathrm{MeC}$ $\left.\left(\mathrm{NC}_{6} \mathrm{H}_{3}{ }^{\mathrm{i}} \mathrm{PrCH}(\mathrm{Me}) \mathrm{CH}_{2}\right) \mathrm{CHC}(\mathrm{Me}) \mathrm{NCH}_{2} \mathrm{CH}_{2} \mathrm{NMe}_{2}\right\} \mathrm{Sc}-$ $\left(\mathrm{NHAr}^{\prime}\right)$ (22), obtained by abstraction of DMAP from $\mathbf{1}^{25}$ Mechanistic and computational (DFT) aspects of the formation of 22 and $\mathbf{2 1}$ are discussed later on.

The scaled-up thermolysis reactions of $\mathbf{1 8}$ in the presence of pyridine or DMAP at $60{ }^{\circ} \mathrm{C}$ gave the pale yellow, orthometalated products $\left(\mathrm{NacNac}^{\mathrm{NMe}_{2}}\right) \mathrm{Sc}\left\{\mathrm{NHB}\left(\mathrm{NAr}{ }^{\prime} \mathrm{CH}\right)_{2}\right\}\left(\eta^{2}-4-\right.$ $\left.\mathrm{NC}_{5} \mathrm{H}_{3} \mathrm{R}\right)\left(\mathrm{R}=\mathrm{H}(23), \mathrm{NMe}_{2}(24)\right)$ in 56 and $85 \%$ isolated yields, respectively (Scheme 2). Although diffraction-quality crystals could not be obtained, their ${ }^{1} \mathrm{H}$ and ${ }^{13} \mathrm{C}$ NMR spectra confirmed that they each have a borylamido ligand and an $\eta^{2}$ bound pyridyl ligand or its DMAP counterpart, apparently formed from $\mathrm{C}-\mathrm{H}$ bond activation at the 2-position of the heterocycle. For example, the ${ }^{1} \mathrm{H}$ NMR spectrum of $\mathbf{2 3}$ has four mutually coupled multiplets for the $\eta^{2}$-pyridyl ligand at 6.89 , 6.80 (overlapping), and $6.48 \mathrm{ppm}$, and a broad $\mathrm{NH}$ singlet at $3.12 \mathrm{ppm}$ for the borylamide ligand. The ${ }^{13} \mathrm{C} N \mathrm{NMR}$ resonance for the Sc-bound pyridyl carbon atom appears at $217.2 \mathrm{ppm}$. These spectral features are comparable to those of Mindiola's crystallographically characterized pyridyl-anilido complex $(\mathrm{PNP}) \mathrm{Sc}\left(\mathrm{NHAr}^{\prime}\right)\left(\eta^{2}-\mathrm{NC}_{5} \mathrm{H}_{4}\right)$ formed by reaction of the methyl-anilide (PNP)Sc(Me)(NHAr') with pyridine at room temperature. ${ }^{11}$ DFT calculations on 23 (vide infra) support the $\eta^{2}$-coordination of the pyridyl ligand in this complex (discussed later). The ${ }^{1} \mathrm{H}$ and ${ }^{13} \mathrm{C}$ NMR spectra of the DMAP counterpart, 24, are analogous to those of 23.

In a further attempt to trap the putative transient imide $\mathbf{2 5}$ (see inset to Scheme 2) formed (vide infra) en route to the C$\mathrm{H}$ activation products 21-24, thermolysis of 18 was carried out in the presence of THF and 2,6-dimethylpyridine at $60{ }^{\circ} \mathrm{C}$ in $\mathrm{C}_{6} \mathrm{D}_{6}$. Unfortunately, in each case this resulted only in quantitative formation of $\mathbf{2 1}$. Therefore, under the conditions necessary to effect methane elimination from 18, these weaker Lewis bases offer insufficient kinetic and/or thermodynamic stabilization against formation of $\mathbf{2 1}$. Furthermore, it was also found that further heating of 23 for $16 \mathrm{~h}$ at the higher temperature of $90{ }^{\circ} \mathrm{C}$ in $\mathrm{C}_{6} \mathrm{D}_{6}$ resulted in conversion to the cyclometalated complex 21 and free pyridine. Labeling and DFT studies below support the mechanism shown in Scheme 3. This conversion from the kinetic product 23 (formed at $60{ }^{\circ} \mathrm{C}$ ) to the thermodynamic product 21 and pyridine (at $90{ }^{\circ} \mathrm{C}$ ) is favored by the entropic gain arising from the elimination of pyridine at higher temperatures. The equivalent process does not take place for the DMAP analogue, 24, for which heating at temperatures above $60{ }^{\circ} \mathrm{C}$ on the NMR tube scale results in

Scheme 3. Conversion of $\left(\mathrm{NacNac}^{\mathrm{NMe}_{2}}\right) \mathrm{Sc}\left\{\mathrm{NHB}\left(\mathrm{NAr} \mathbf{C H}_{2}\right\}\left(\boldsymbol{\eta}^{2}-\mathrm{NC}_{5} \mathrm{H}_{4}\right)\right.$ (23) to

$\left\{\mathrm{MeC}\left(\mathrm{NC}_{6} \mathrm{H}_{3}{ }^{\mathrm{i}} \mathrm{PrCH}(\mathrm{Me}) \mathrm{CH}_{2}\right) \mathrm{CHC}(\mathrm{Me}) \mathrm{NCH}_{2} \mathrm{CH}_{2} \mathrm{NMe}_{2}\right\} \mathrm{Sc}\left\{\mathrm{NHB}\left(\mathrm{NAr}^{\prime} \mathrm{CH}\right)_{2}\right\}$

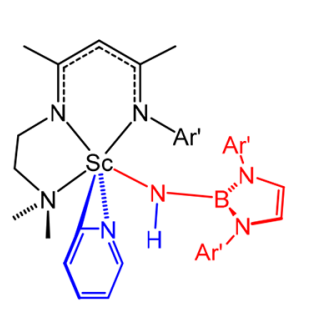

23

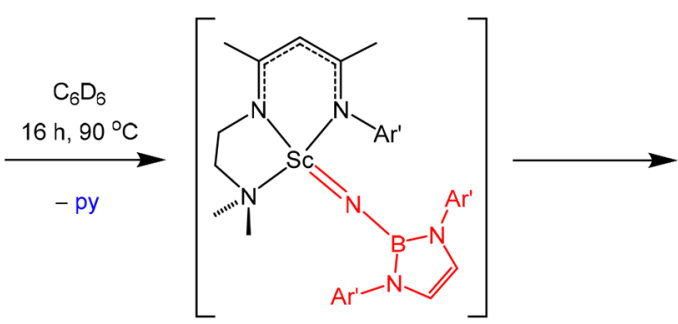

25

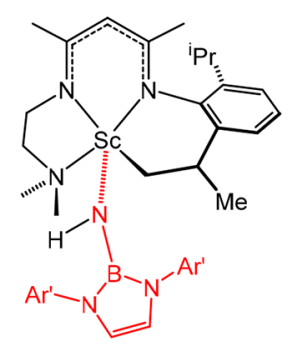

21 
conversion to a complex mixture of products which cannot be identified.

As mentioned, Chen recently reported the anilido analogue of 21 (i.e., 22) by reaction of 1 with ${ }^{\mathrm{t}} \mathrm{BuCH}_{2} \mathrm{CH}_{2} \mathrm{BC}_{8} \mathrm{H}_{14}$, at room temperature or $50{ }^{\circ} \mathrm{C}$. This reaction is proposed to proceed via transient $\left(\mathrm{NacNac}^{\mathrm{NMe}_{2}}\right) \mathrm{Sc}\left(\mathrm{NAr}^{\prime}\right){ }^{25}$ It was also reported that heating $\left(\mathrm{NacNac}^{\mathrm{NMe}_{2}}\right) \mathrm{Sc}(\mathrm{Me})\left(\mathrm{NHAr}^{\prime}\right)$ (19) itself (the analogue of 18) gave no reaction after $48 \mathrm{~h}$ at $70{ }^{\circ} \mathrm{C}$, which is in contrast to our observation of the ready conversion of 18 to 21 and methane at $60{ }^{\circ} \mathrm{C}$ within several hours. In addition, it was not clear from the published work whether 1 could undergo further reaction on heating, converting for example to the anilido analogue of $\mathbf{2 4}$ or to $\mathbf{2 2}$. To avoid mechanistic uncertainties in connection with the DFT studies reported later on in this paper, we therefore independently prepared 19 and 1 and studied their thermolysis chemistry. Despite extended heating at $90{ }^{\circ} \mathrm{C}$ in $\mathrm{C}_{6} \mathrm{D}_{6}, \mathbf{1}$ was found to be thermally stable. In contrast, however, heating 19 at $70{ }^{\circ} \mathrm{C}$ for 8 $\mathrm{h}$ gave complete consumption of the anilide and formation of $\mathbf{2 2}$ as the major product. The half-life for the decay of $\mathbf{1 9}$ was found to be $\sim 1.1 \mathrm{~h}$, which is comparable to the half-life of 18 in conversion to 21 under the same conditions $(\sim 1.2 \mathrm{~h})$.

Mechanism. On their own, the thermolysis reactions of $\mathbf{1 8}$ (Scheme 2) do not establish that the mechanism of formation of 21, 23, and 24 proceeds via an imido intermediate such as $\mathbf{2 5}$ (inset to Scheme 2) at all. Mechanisms proceeding via direct $\sigma$ bond metathesis at the $\mathrm{Sc}-\mathrm{Me}$ bond in systems of this type are precedented. $^{26}$ Furthermore, for the reactions with py or DMAP, the data do not establish whether or not Lewis base assistance occurs, again as found in previous systems. ${ }^{26 \mathrm{~b}}$

These three thermolysis reactions of $\mathbf{1 8}$ were monitored by ${ }^{1} \mathrm{H}$ NMR spectroscopy at $343 \mathrm{~K}$ in duplicate for at least three half-lives ( $>85 \%$ consumption of 18). All followed first-order kinetics as judged by linear semilogarithmic plots of $-\ln ([\mathbf{1 8}] /$ $[18]_{0}$ ) vs time (see Figure S3 of the SI). The overall first-order rate constants $(k)$ for all three reactions are listed in Table 1 . All

Table 1. First-Order Rate Constants $(k)$ for the Base-Free Thermolysis of $\left(\mathrm{NacNac}^{\mathrm{NMe}_{2}}\right) \mathrm{Sc}(\mathrm{Me})\left\{\mathrm{NHB}\left(\mathrm{NAr}{ }^{\prime} \mathrm{CH}\right)_{2}\right\}$ (18) To Form $\left\{\mathrm{MeC}\left(\mathrm{NC}_{6} \mathrm{H}_{3}{ }^{\mathrm{i}} \mathrm{PrCH}(\mathrm{Me}) \mathrm{CH}_{2}\right) \mathrm{CH}-\right.$ $\left.\mathrm{C}(\mathrm{Me}) \mathrm{NCH}_{2} \mathrm{CH}_{2} \mathrm{NMe}_{2}\right\} \mathrm{Sc}\left\{\mathrm{NHB}\left(\mathrm{NAr}^{\prime} \mathrm{CH}\right)_{2}\right\}$ (21), and with Pyridine and DMAP To Form

$\left(\mathrm{NacNac}^{\mathrm{NMe}_{2}}\right) \mathbf{S c}\left\{\mathrm{NHB}\left(\mathrm{NAr}{ }^{\prime} \mathrm{CH}\right)_{2}\right\}\left(\boldsymbol{\eta}^{2}-4-\mathrm{NC}_{5} \mathrm{H}_{3} \mathrm{R}\right)(\mathrm{R}=\mathbf{H}$ (23), $\left.\mathrm{NMe}_{2}(24)\right)$, along with Deuterated Variants, at $343 \mathrm{~K}$ in $\mathrm{C}_{6} \mathrm{D}_{6}{ }^{a}$

\begin{tabular}{ccccc} 
& & & \multicolumn{2}{c}{$k / 10^{-5} \mathrm{~s}^{-1}$} \\
\cline { 4 - 5 } starting material $^{b}$ & Lewis base $^{c}$ & product & run 1 & run 2 \\
$\mathbf{1 8}$ & - & $\mathbf{2 1}$ & $16.8(1)$ & $15.6(1)$ \\
$\mathbf{1 8}-\boldsymbol{d}_{\mathbf{1}}$ & - & $\mathbf{2 1}$ & $1.91(1)$ & $1.82(1)$ \\
$\mathbf{1 8}$ & py & $\mathbf{2 3}$ & $17.3(1)$ & $16.9(1)$ \\
$\mathbf{1 8}$ & py- $d_{5}$ & $\mathbf{2 3}-\boldsymbol{d}_{5}$ & $18.7(1)$ & $18.3(1)$ \\
$\mathbf{1 8}$ & DMAP & $\mathbf{2 4}$ & $17.8(1)$ & $18.0(1)$
\end{tabular}

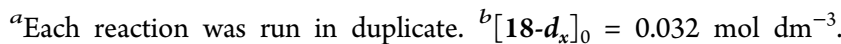
${ }^{c}[\text { Lewis base }]_{0}=0.032 \mathrm{~mol} \mathrm{dm}^{-3}$.

three reactions have comparable $k$ values, implying that they share a common rate-determining step. The very similar rate constants for pyridine and DMAP (DMAP being a much stronger nucleophile than pyridine ${ }^{27}$ ) show that base-assisted methane elimination is not involved in a rate-determining step, in contrast to the corresponding reaction of related systems and specifically the anilido analogue of $18 .{ }^{5}$
Deuterium labeling was used to gain additional information on the mechanism. Selectively ND-labeled $\left(\mathrm{NacNac}^{\mathrm{NMe}_{2}}\right) \mathrm{Sc}$ $(\mathrm{Me})\left\{\mathrm{NDB}\left(\mathrm{NAr}{ }^{\prime} \mathrm{CH}\right)_{2}\right\} \quad\left(\mathbf{1 8}-d_{1}\right)$ was prepared using $\mathrm{D}_{2} \mathrm{NB}-$ $\left(\mathrm{NAr}{ }^{\prime} \mathrm{CH}\right)_{2}\left(\mathbf{1 2}-d_{2}\right)$. The ${ }^{1} \mathrm{H}$ NMR spectrum of the labeled borylamide is identical to that of $\mathbf{1 8}$ except for the absence of an $\mathrm{N} \underline{\mathrm{H}}$ singlet. Thermolysis of $\mathbf{1 8}-\boldsymbol{d}_{\mathbf{1}}$ gave conversion exclusively to 21 containing a hydrogen (relative intensity 1 $\mathrm{H})$ at the borylamide $(\mathrm{NH})$ site, with the N-bound deuterium of 18- $d_{1}$ being eliminated as $\mathrm{MeD}$ to apparently form the imide 25 prior to the intramolecular $\mathrm{C}-\mathrm{H}$ bond activation. An alternative mechanism ${ }^{26 \mathrm{~b}}$ in which the metalation occurs by $\sigma$ bond metathesis between $\mathrm{Sc}-\mathrm{Me}$ and the isopropyl $\mathrm{C}-\mathrm{H}$ bond would necessarily release $\mathrm{CH}_{4}$ and form a species (21- $\boldsymbol{d}_{\mathbf{1}}$ ) containing a $\mathrm{ScNDB}\left(\mathrm{NAr}{ }^{\prime} \mathrm{CH}\right)_{2}$ moiety.

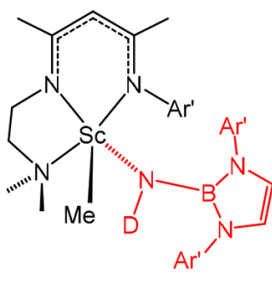

$18-d_{1}$

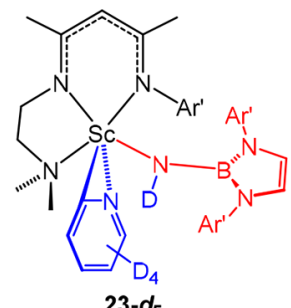

23- $d_{5}$
The corresponding thermolysis reaction of $\mathbf{1 8}$ in the presence of pyridine- $d_{5}$ was performed under the same conditions. The product was found to be exclusively $\left(\mathrm{NacNac}{ }^{\mathrm{NMe}_{2}}\right) \mathrm{Sc}\left\{\mathrm{NDB}\left(\mathrm{NAr}{ }^{\prime} \mathrm{CH}\right)_{2}\right\}\left(\eta^{2}-\mathrm{NC}_{5} \mathrm{D}_{4}\right) \quad\left(23-d_{5}\right)$, and a singlet assigned to $\mathrm{CH}_{4}(0.16 \mathrm{ppm})$ was observed in the ${ }^{1} \mathrm{H}$ NMR spectrum of the reaction mixture. The ${ }^{1} \mathrm{H}$ NMR spectrum of $23-d_{5}$ is identical to that of 23 , other than the absence of the borylamide $\mathrm{NH}$ singlet and all of the pyridyl multiplets. Consistent with Scheme 3, thermolysis of 23- $\boldsymbol{d}_{5}$ at $90{ }^{\circ} \mathrm{C}$ in $\mathrm{C}_{6} \mathrm{D}_{6}$ or $\mathrm{C}_{6} \mathrm{H}_{6}$ formed exclusively 21 and pyridine- $d_{5}$, with no incorporation of hydrogen into the eliminated Lewis base.

In addition, the rate of formation of $\mathbf{2 1}$ by thermolysis of 18$d_{1}$ was found to be significantly slower than that of 18 , with a kinetic isotope effect (KIE) at $343 \mathrm{~K}$ of $8.7 \pm 0.5$ (Table 1, average of two independent values). The KIE value obtained here, albeit large compared to classical organic systems, is very comparable to those reported by Bergman, Wolczanski, and others for $\alpha$-abstraction reactions in Group 4 and 5 systems which release methane or other alkanes to yield organoimido functional groups, ${ }^{28}$ as well as a number of other examples. ${ }^{28 \mathrm{~h}, \mathrm{i}}$ The magnitudes of these isotope effects, their origins, and any contributions (or not) from nonclassical mechanisms have been discussed in these previous papers and reviews, ${ }^{28 h, i}$ and the reader is referred to them for further discussion. The observed KIE value reported here is indicative of a process having a transition state (TS) in which the transfer of $\mathrm{H}$ is relatively linear. ${ }^{29}$ We discuss the geometry of the DFT computed TS later on in this paper. In contrast, thermolysis of $\mathbf{1 8}$ in the presence of pyridine- $d_{5}$ gave no significant rate difference to the reaction with protio-pyridine.

Taken all together, these results are consistent with the pathways shown in Scheme 4. Compound 18 undergoes ratedetermining methane-elimination without base assistance in all instances to form the transient borylimide 25, which in turn undergoes rapid cyclometalation, except in the presence of py or DMAP which ultimately form $\mathbf{2 3}$ or $\mathbf{2 4}$. Adducts of the type 23 int and 24 int are implicated but not directly observed, being apparently thermodynamically unstable with regard to 
Scheme 4. Proposed Pathways for the Thermolysis Reactions of $\left(\mathrm{NacNac}^{\mathrm{NMe}_{2}}\right) \mathrm{Sc}(\mathrm{Me})\left\{\mathrm{NHB}\left(\mathrm{NAr} \mathbf{C H}_{2}\right\}(18)\right.$

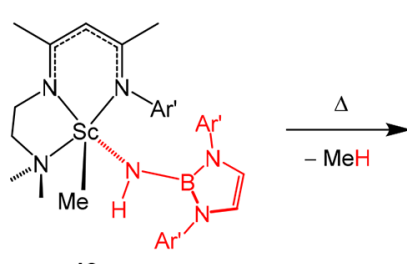

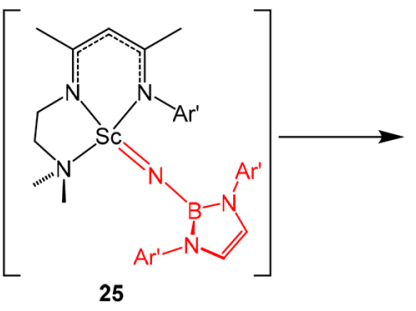

observed
for py $\uparrow \begin{array}{r}\text { py or } \\ \text { DMAP }\end{array}$

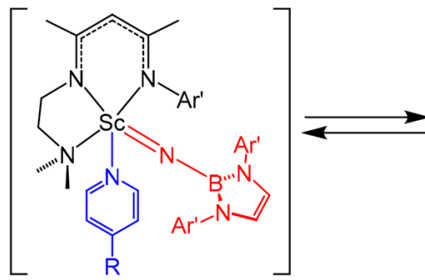

$\mathrm{R}=\mathrm{H}(\mathbf{2 3}$ int $)$ or $\mathrm{NMe}_{2}$ (24_int)

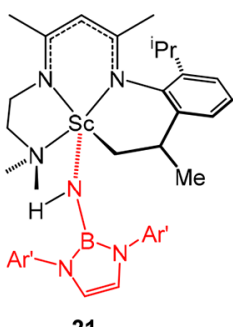

21

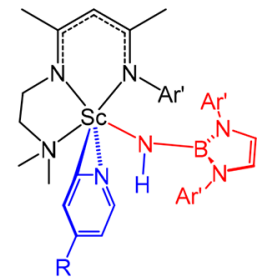

$\mathrm{R}=\mathrm{H}(\mathbf{2 3})$ or $\mathrm{NMe}_{2}(\mathbf{2 4})$

Scheme 5. Intramolecular Competition Reaction of $\left(\mathrm{NacNac}^{\mathrm{NMe}_{2}}\right) \mathrm{Sc}(\mathrm{Me})\left\{\mathrm{NHB}\left(\mathrm{NAr}^{\prime} \mathrm{CH}\right)_{2}\right\}(18)$ with 2-Pyridine- $d_{1}{ }^{a}$

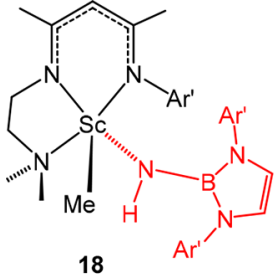

18

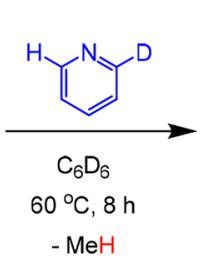

$\mathrm{MeH}$

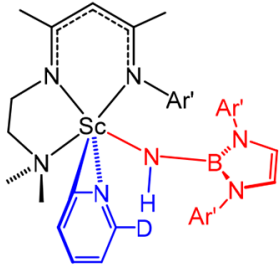

$60 \%$

23- $d_{1}$ C

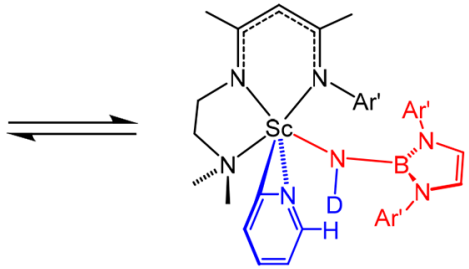

$40 \%$

$23-d_{1} N$

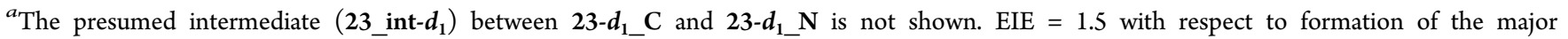
isotopomer.

the ortho-metalated isomers, unlike in the case of Chen's arylimido analogue of 24_int, $\left(\mathrm{NacNac}^{\mathrm{NMe} 2}\right) \mathrm{Sc}\left(\mathrm{NAr}^{\prime}\right)$ (DMAP) (1). These results contrast with the base-assisted thermolysis of $\left(\mathrm{NacNac}^{\mathrm{NMe} 2}\right) \mathrm{Sc}(\mathrm{Me})\left(\mathrm{NHAr}^{\prime}\right)$ in the presence of DMAP to form the stable $1 .^{5}$ In that case an adduct $\left(\mathrm{NacNac}^{\mathrm{NMe} 2}\right) \mathrm{Sc}$ $(\mathrm{Me})\left(\mathrm{NHAr}^{\prime}\right)$ (DMAP) is observed prior to formation of $\mathbf{1}$, whereas in the case of $\mathbf{1 8}$ none is seen.

Related $\mathrm{C}-\mathrm{H}$ bond activation reactions of coordinated pyridine by a scandium terminal imide have been reported by Mindiola and co-workers, ${ }^{11,12}$ as have a number of similar reactions by other early transition or rare earth metal systems. ${ }^{30}$ Heating ( $\mathrm{PNP}) \mathrm{Sc}(\mathrm{Me})\left(\mathrm{NHAr}^{\prime}\right)$ in the presence of pyridine generates a transient scandium imide (PNP)Sc(NAr')(py) which then (rapidly) activates a $\mathrm{C}-\mathrm{H}$ bond of pyridine to form the pyridyl complex (PNP)Sc(NHAr' ${ }^{\prime}\left(\eta^{2}-\mathrm{NC}_{5} \mathrm{H}_{4}\right)$. Mechanistic studies showed that pyridine coordinates to (PNP) $\mathrm{Sc}(\mathrm{Me})$ $\left(\mathrm{NHAr}^{\prime}\right)$ before $\alpha$-abstraction. ${ }^{11 \mathrm{~b}}$ Significantly, the reaction with DMAP was almost 2 orders of magnitude faster than that with pyridine. This contrasts with the formation of 23 and 24, which have comparable rates because pyridine and DMAP coordinate only after the rate-determining, $\alpha$-abstraction step. The mechanistic difference with regard to base assistance between the systems of Chen and Mindiola and the one reported here is proposed to have a steric basis, and DFT studies (vide infra) support this conclusion.
As mentioned, 23 and $23-d_{5}$ can be converted to 21 and py or py- $d_{5}$, suggesting a number of accessible equilibria, as indicated in Scheme 4. Consistent with this it was found that addition of 1 equiv of pyridine- $d_{5}$ to 23 on the NMR tube scale in $\mathrm{C}_{6} \mathrm{D}_{6}$ resulted in an equilibrium mixture of $56 \% 23$ and $44 \%$ 23- $d_{5}$ after heating at $60{ }^{\circ} \mathrm{C}$ for $2 \mathrm{~h}$, indicative of a modest equilibrium isotope effect and showing that interconversion between 23 int and 23 is facile under the experimental conditions required to form the latter from $18\left(10 \mathrm{~h}\right.$ at $60{ }^{\circ} \mathrm{C}$ under the same reagent concentrations).

The overall equilibrium isotope effect observed in the intermolecular exchange reaction of pyridine- $d_{5}$ with 23 involves a series of interconverting, individual equilibria between 23 and 23 int (and their isotopomers) as well as $\mathbf{2 5}$ (assuming that exchange between 23 int and free pyridine (or their isotopomers) is a dissociative process). In order to isolate the specific $\mathrm{C}-\mathrm{H}(\mathrm{D})$ bond activation step between 23 int and 23, an intramolecular competition reaction was performed through thermolysis of $\mathbf{1 8}$ in the presence of 2-pyridine- $d_{1}$ (Scheme 5). After $8 \mathrm{~h}$ at $60{ }^{\circ} \mathrm{C}$ in $\mathrm{C}_{6} \mathrm{D}_{6}$ this resulted in an isotopomer mixture of $60 \%\left(\mathrm{NacNac} \mathrm{NMe}_{2}\right) \mathrm{Sc}\{\mathrm{NHB}$ $\left.\left(\mathrm{NAr}{ }^{\prime} \mathrm{CH}\right)_{2}\right\}\left(\eta^{2}-6-\mathrm{NC}_{5} \mathrm{H}_{3} \mathrm{D}\right) \quad\left(23-d_{1} \mathrm{C}\right)$ and $40 \%$ $\left(\mathrm{NacNac}^{\mathrm{NMe}_{2}}\right) \mathrm{Sc}\left\{\mathrm{NDB}\left(\mathrm{NAr}{ }^{\prime} \mathrm{CH}\right)_{2}\right\}\left(\eta^{2}-\mathrm{NC}_{5} \overline{\mathrm{H}}_{4}\right) \quad(\mathbf{2 3}-\boldsymbol{d} \mathbf{1} \mathbf{N})$. The equilibrium isotope effect of 1.5 is comparable with the value found in the intermolecular competition reaction. The 
Scheme 6. Synthesis of $\left(\mathrm{NacNac}^{\mathrm{NMe}_{2}}\right) \operatorname{Sc}\left\{\mathrm{NHB}\left(\mathrm{NAr}^{\prime} \mathrm{CH}\right)_{2}\right\}(\mathrm{CCTol})(26)$ and $\left(\mathrm{NacNac}^{\mathrm{NMe}_{2}}\right) \operatorname{Sc}\left\{\mathrm{N}\left\{\mathrm{B}\left(\mathrm{NAr} \mathbf{C}^{\prime} \mathrm{CH}\right)_{2}\right\} \mathrm{C}(\mathrm{Me}) \mathrm{C}(\mathrm{Ph})\right\}$ (27)

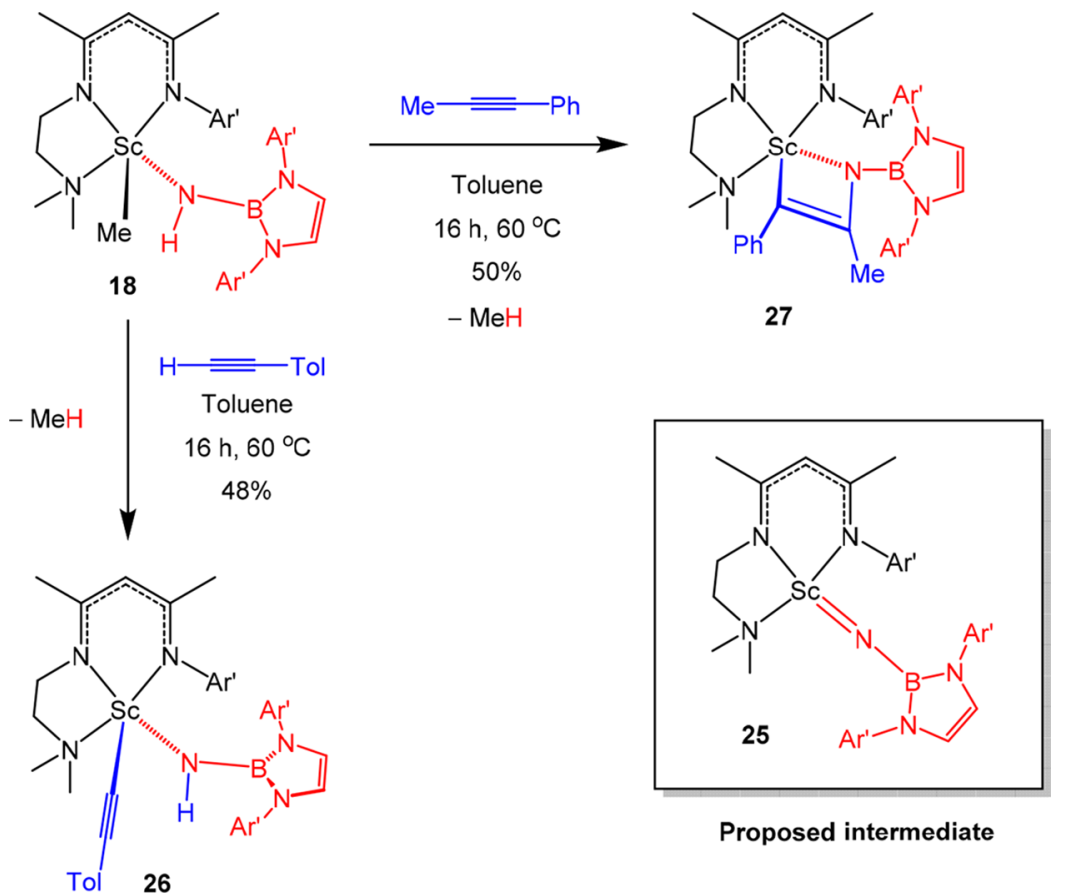

ratio of $23-d_{1} \_$C:23- $d_{1} \_\mathbf{N}$ remained constant throughout and after the reaction.

Trapping of a Transient Scandium Borylimide with Alkynes. To further probe the transient borylimide 25, we performed trapping reactions starting from the methylborylamide 18 in the presence of various terminal and internal alkynes. On the NMR tube scale, the reaction of 1 equiv of either $\mathrm{HCCT}$ ol or $\mathrm{MeCCPh}$ with 18 at $60^{\circ} \mathrm{C}$ gave quantitative conversion to a single new product in each case after $8 \mathrm{~h}$. On the preparative scale, the reaction with $\mathrm{HCCTol}$ in toluene gave the terminal acetylide $\left(\mathrm{NacNac}^{\mathrm{NMe}_{2}}\right) \mathrm{Sc}\left\{\mathrm{NHB}\left(\mathrm{NAr}^{\prime} \mathrm{CH}\right)_{2}\right\}$ (CCTol) (26) as an off-white powder in $50 \%$ yield (Scheme 6). The corresponding reaction with $\mathrm{MeCCPh}$ gave the azascandacyclobutene $\left(\mathrm{NacNac}^{\mathrm{NMe}_{2}}\right) \mathrm{Sc}\left\{\mathrm{N}\left\{\mathrm{B}\left(\mathrm{NAr}{ }^{\prime} \mathrm{CH}\right)_{2}\right\} \mathrm{C}\right.$ $(\mathrm{Me}) \mathrm{C}(\mathrm{Ph})\} \quad(27)$ as a yellow powder in $48 \%$ yield. Compounds 26 and 27 represent the products of alkyne C$\mathrm{H}$ bond activation (1,2-addition) or [2+2] cycloaddition across the $\mathrm{Sc}-\mathrm{N}$ multiple bond of transient $\mathbf{2 5}$. Attempted reactions with two further internal alkynes were unsuccessful. NMR tube scale thermolysis in the presence of $\mathrm{MeCCMe}$ resulted in a mixture of unknown products, whereas thermolysis in the presence of $\mathrm{PhCCPh}$ gave only the cyclometalated complex 21, the bulkier internal alkyne being too sterically demanding to compete with the intramolecular bond-activation process.

The ${ }^{1} \mathrm{H}$ and ${ }^{13} \mathrm{C}$ NMR spectra of $\mathbf{2 6}$ are consistent with the presence of an acetylide group in addition to a borylamido ligand. The $\mathrm{NH}$ singlet is found at $3.58 \mathrm{ppm}$ in the ${ }^{1} \mathrm{H}$ NMR spectrum, and the two acetylide carbons give ${ }^{13} \mathrm{C}$ resonances at 155.4 and $124.6 \mathrm{ppm}$ for the carbons bonded to the metal and to the $p$-tolyl group, respectively. The ${ }^{13} \mathrm{C}$ NMR spectrum of 27 is consistent with the azascandacyclobutene unit having the regiochemistry illustrated in Scheme 6, with the metal-bound $\mathrm{Sc} \underline{\mathrm{C}}(\mathrm{Ph})$ carbon appearing at $172.9 \mathrm{ppm}$, and the $\mathrm{C} \underline{\mathrm{CMe}}$ counterpart at $154.5 \mathrm{ppm}$. Diffraction-quality crystals of complex 27 were grown from a benzene solution. The solid- state structure is shown in Figure 5, along with key bond distances and angles.

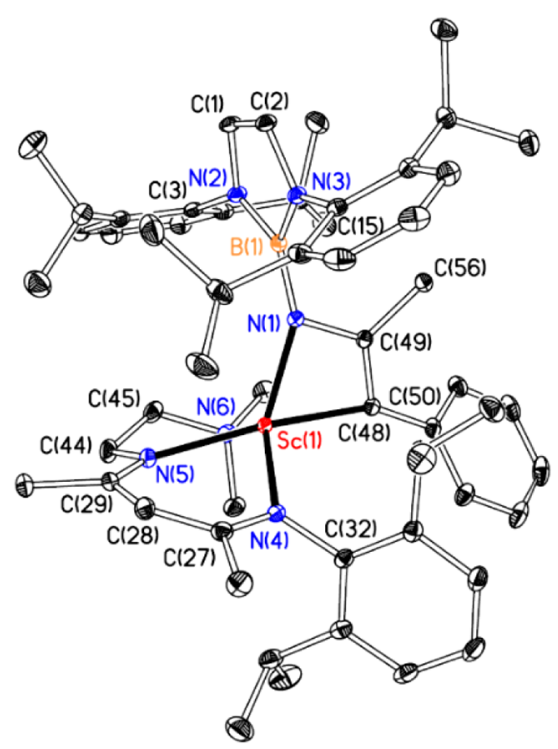

Figure 5. Displacement ellipsoid plot $(20 \%$ probability $)$ of $\left(\mathrm{NacNac}^{\mathrm{NMe}_{2}}\right) \mathrm{Sc}\left\{\mathrm{N}\left\{\mathrm{B}\left(\mathrm{NAr}{ }^{\prime} \mathrm{CH}\right)_{2}\right\} \mathrm{C}(\mathrm{Me}) \mathrm{C}(\mathrm{Ph})\right\} \quad$ (27). H atoms omitted. Selected bond distances $(\AA)$ and angles (deg): $\mathrm{Sc}(1)-\mathrm{N}(1)$ 2.0528(7), Sc(1)-C(48) 2.1578(8), N(1)-B(1) 1.4397(11), N(1)$\mathrm{C}(49)$ 1.4393(10), C(48)-C(49) 1.3706(11), N(1)-Sc(1)-C(48) 70.12(3), $\mathrm{Sc}(1)-\mathrm{N}(1)-\mathrm{B}(1) 1511.33(6)(\tau=0.53)$.

Complex 27 possesses a distorted five-coordinate geometry $(\tau=0.53)$, with the bidentate $\mathrm{N}(1)-\mathrm{C}(49)-\mathrm{C}(48)$ unit of the metallacycle having the regiochemistry expected from the ${ }^{13} \mathrm{C}$ NMR data, and a $\mathrm{N}(1)-\mathrm{Sc}(1)-\mathrm{C}(48)$ angle of $70.12(3)^{\circ}$. The structure of 27 may be compared with that of $\left(\mathrm{NacNac}^{\mathrm{NMe}_{2}}\right)$ $\mathrm{Sc}\left\{\mathrm{N}\left(\mathrm{Ar}^{\prime}\right) \mathrm{C}(\mathrm{Me}) \mathrm{C}(\mathrm{Ph})\right\}$ (28), which was prepared by Chen 
and co-workers by abstraction of the DMAP ligand from 1 using $9-\mathrm{BBN}$ in the presence of $\mathrm{MeCCPh} .{ }^{25}$ The metallacycle $\mathrm{N}(1)-\mathrm{Sc}(1)-\mathrm{C}(48)$ angle of $69.92(13)^{\circ}$ in 28 is comparable to that in 27. The $\mathrm{N}(1)-\mathrm{C}(49)$ and metallacycle $\mathrm{C}(49)-$ $\mathrm{C}(50)$ bond lengths are also comparable and consistent with $\mathrm{N}-\mathrm{C}$ single and $\mathrm{C}-\mathrm{C}$ double bonds. A related scandium anilide-acetylide, $\left({ }^{\mathrm{tBu}} \mathrm{NacNac}\right) \mathrm{Sc}\left(\mathrm{NHAr}^{\prime}\right)(\mathrm{CCPh})$, was recently prepared by Piers and co-workers via a $\mathrm{C}-\mathrm{H}$ bond activation reaction of $\mathrm{HCCPh}$ with 3 (Figure 1) at $70{ }^{\circ} \mathrm{C}$ and was crystallographically characterized. ${ }^{7}$ Mechanistic studies showed that, like Chen's 28, this also formed after initial dissociation of the DMAP ligand.

The reactions of $\mathbf{1 8}$ with $\mathrm{HCCT}$ ol or $\mathrm{MeCCPh}$ were monitored by ${ }^{1} \mathrm{H}$ NMR spectroscopy at $343 \mathrm{~K}$, as for the previous thermolysis experiments. Both followed first-order kinetics (see Figure S4 of the SI for semilogarithmic plots of $-\ln \left([18] /[18]_{0}\right)$ vs time $)$. The observed first-order rate constants are listed in Table 2 . These values are similar to

Table 2. First-Order Rate Constants $(k)$ Obtained for the Thermolysis of $\left(\mathrm{NacNac}^{\mathrm{NMe}_{2}}\right) \mathrm{Sc}(\mathrm{Me})\left\{\mathrm{NHB}\left(\mathrm{NAr} \mathbf{r}^{\prime} \mathrm{CH}\right)_{2}\right\}$ (18) with XCCTol $(\mathrm{X}=\mathrm{H}$ or $\mathrm{D})$ and MeCCPh To Form $\left(\mathrm{NacNac}^{\mathrm{NMe}_{2}}\right) \mathrm{Sc}\left\{\mathrm{NXB}\left(\mathrm{NAr}{ }^{\prime} \mathrm{CH}\right)_{2}\right\}(\mathrm{CCTol})(\mathrm{X}=\mathrm{H}(26)$ or $\left.\mathrm{D}\left(26-d_{1}\right)\right)$ and $\left(\mathrm{NacNac}^{\mathrm{NMe}_{2}}\right) \mathrm{Sc}\left\{\mathrm{N}\left\{\mathrm{B}\left(\mathrm{NAr}^{\prime} \mathrm{CH}\right)_{2}\right\} \mathrm{C}(\mathrm{Me}) \mathrm{C}(\mathrm{Ph})\right\}(27)$ at 343 $\mathrm{K}$ in $\mathrm{C}_{6} \mathrm{D}_{6}{ }^{a}$

\begin{tabular}{ccccc} 
& & & \multicolumn{2}{c}{$k / 10^{-5} \mathrm{~s}^{-1}$} \\
\cline { 4 - 5 } starting material $^{b}$ & reagent $^{c}$ & product & run 1 & run 2 \\
$\mathbf{1 8}$ & HCCTol & $\mathbf{2 6}$ & $16.9(1)$ & $17.4(1)$ \\
18 & DCCTol & $\mathbf{2 6 - d _ { 1 }}$ & $17.8(1)$ & $17.3(1)$ \\
18 & MeCCPh & $\mathbf{2 7}$ & $16.6(1)$ & $18.4(1)$
\end{tabular}

${ }^{a}$ Each reaction was run in duplicate. ${ }^{b}[\mathbf{1 8}]_{0}=0.032 \mathrm{~mol} \mathrm{dm}{ }^{-3}$. c [alkyne $]_{0}=0.032 \mathrm{~mol} \mathrm{dm}^{-3}$.

each other and to those in Table 1, consistent with the bondforming events for 26 and 27 occurring after initial $\alpha$-hydrogen abstraction to release methane as the rate-determining step. As expected, reaction of $\mathbf{1 8}$ with DCCTol gave elimination of $\mathrm{CH}_{4}$ and exclusive incorporation of deuterium at the borylamide site

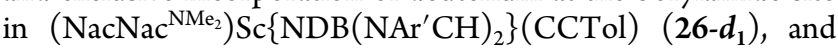
no KIE was observed between the reactions of HCCTol and DCCTol. A competition reaction between $\mathbf{1 8}$ and a mixture of HCCTol and DCCTol (1:5:5 ratio, so as to determine any isotope effect in the alkyne $\mathrm{C}-\mathrm{H}$ bond activation reaction of transient 25) was not clean, probably due to competing side reactions in the presence of an excess of terminal alkyne.

In a competition reaction of $\mathbf{1 8}$ with $\mathrm{HCCT}$ ol and $\mathrm{MeCCPh}$ (1:5:5 molar ratio) at $60{ }^{\circ} \mathrm{C}$ in $\mathrm{C}_{6} \mathrm{D}_{6}$, quantitative conversion to the acetylide complex 26 was observed, indicating that the $\mathrm{C}-$ $\mathrm{H}$ bond activation of HCCTol by 25 is at least $2-3$ orders of magnitude faster than $[2+2]$ cycloaddition with $\mathrm{MeCCPh}$. In a separate experiment, addition of HCCTol to 27 gave no significant reaction even at $90{ }^{\circ} \mathrm{C}$. Addition of 1 equiv of $\mathrm{MeCCPh}$ to 26 and heating up to $90{ }^{\circ} \mathrm{C}$ in $\mathrm{C}_{6} \mathrm{D}_{6}$ likewise gave no exchange with the added alkyne, and 26 appeared to be thermally stable at this temperature. Therefore, although HCCTol reacts faster than $\mathrm{MeCCPh}$ with the proposed transient imide 25, we have no information on their relative thermodynamic stabilities, or on whether a hypothetical $[2+2]$ cycloaddition product (not seen with HCCTol) is thermodynamically competitive with 26 .

Trapping of the base-free borylimide 25 by $\mathrm{MeCCPh}$ was also achieved from the cyclometalated 21. When heated at 100 ${ }^{\circ} \mathrm{C}$ in the presence of 1 equiv of $\mathrm{MeCCPh}$, conversion to 27 took place over $16 \mathrm{~h}$ to reach completion. At this temperature 21 is therefore able to re-form the borylimide 25 before being trapped. In contrast, heating 23 in the presence of 1 equiv of $\mathrm{MeCCPh}$ at $60{ }^{\circ} \mathrm{C}$ did not result in conversion to 27 , despite earlier exchange reactions showing that the reaction of pyridine with 25 is reversible at this temperature. In an analogous competition reaction of $\left(\mathrm{NacNac}^{\mathrm{NMe}_{2}}\right) \mathrm{Sc}(\mathrm{Me})\{\mathrm{NHB}$ $\left.\left(\mathrm{NAr}{ }^{\prime} \mathrm{CH}\right)_{2}\right\}$ (18) between pyridine and $\mathrm{MeCCPh}(1: 5: 5)$ at $60{ }^{\circ} \mathrm{C}$, exclusive formation of 23 was also observed. It appears

Table 3. ${ }^{\mathrm{R}} \mathrm{NacNac}^{\mathrm{NMe}_{2}}$ and Imide/Amide Ligand Substituents Used in the DFT Calculations ${ }^{a}$

Model series

${ }^{a} \mathrm{Ar}^{\prime}=2,6-\mathrm{C}_{6} \mathrm{H}_{3}{ }^{\mathrm{i}} \mathrm{Pr}_{2}$ and $\mathrm{Xyl}=2,6-\mathrm{C}_{6} \mathrm{H}_{3} \mathrm{Me}_{2}$. All ligands are shown in their neutral forms. 

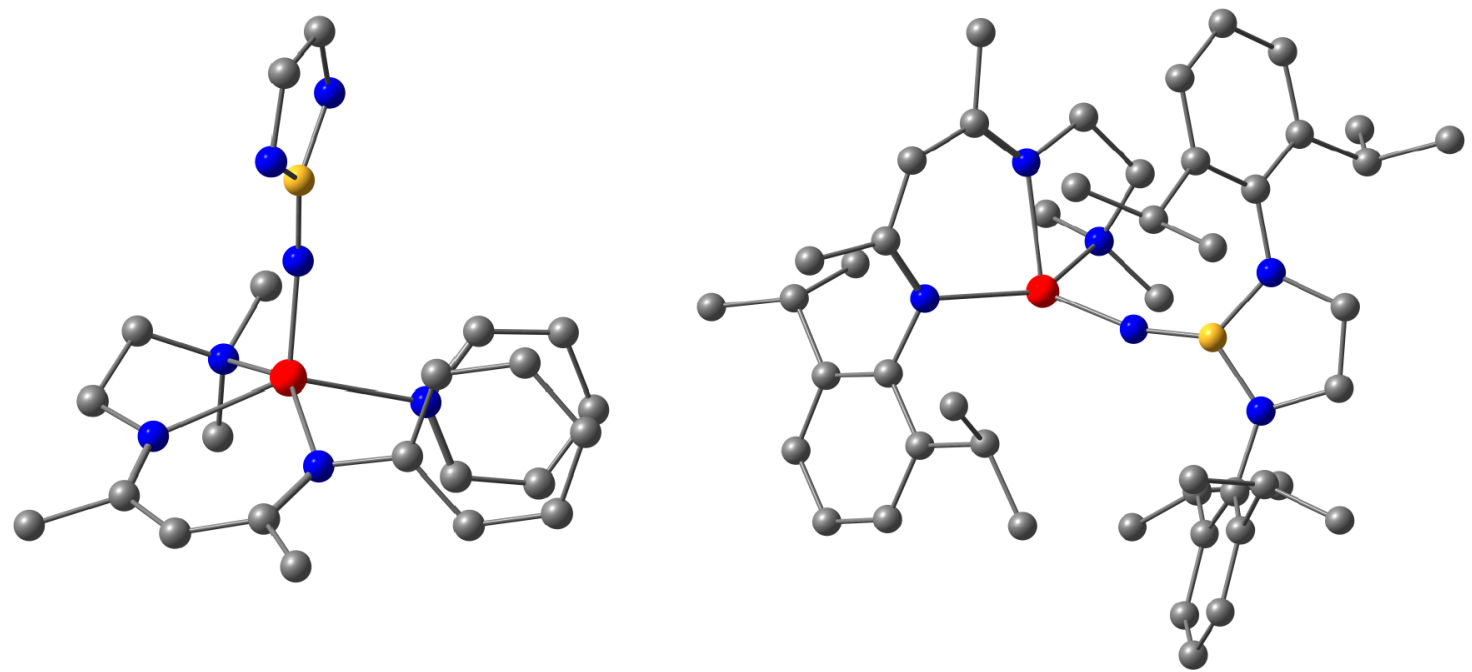

Figure 6. DFT computed structures of $\left({ }^{\mathrm{Ph}} \mathrm{NacNac}^{\mathrm{NMe}}\right) \mathrm{Sc}\left\{\mathrm{NB}(\mathrm{NHCH})_{2}\right\}($ py) (1q_E right). $\mathrm{H}$ atoms omitted. Color code: Sc, red; N, blue; B, yellow; C, gray.

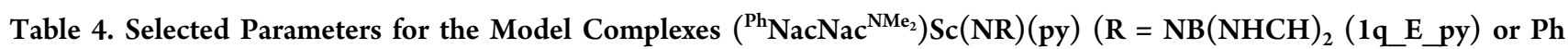
$\left.\left(2 \mathrm{q} \_\mathrm{E} \_\mathrm{py}\right)\right)^{a}$

\begin{tabular}{|c|c|c|c|c|c|c|c|c|c|c|c|}
\hline model & $\begin{array}{c}d\left(\mathrm{Sc}-\mathrm{N}_{\text {imide }}\right) \\
(\AA)\end{array}$ & $\begin{array}{c}\Delta E_{\mathrm{BD}} \\
\left.(\mathrm{kcal} \mathrm{mol})^{-1}\right)\end{array}$ & $\begin{array}{l}\text { Mayer bond } \\
\text { index }\end{array}$ & $\delta$ & $\rho$ & $\nabla^{2} \rho$ & $\varepsilon$ & $H$ & $\sum Q(\mathrm{NR})$ & $Q(\mathrm{Sc})$ & $\sum Q\left({ }^{\mathrm{Ph}} \mathrm{NacNac}^{\mathrm{NMe}_{2}}\right)$ \\
\hline 1q_E_py & 1.829 & $116.7(129.6)$ & 1.646 & 1.173 & 0.152 & 0.560 & 0.022 & -0.056 & -1.186 & 1.885 & -0.735 \\
\hline $2 q$ E py & 1.835 & $106.0(119.0)$ & 1.535 & 1.083 & 0.141 & 0.613 & 0.074 & -0.045 & -1.229 & 1.894 & -0.706 \\
\hline
\end{tabular}

${ }^{a} \mathrm{Sc}-\mathrm{N}_{\mathrm{im}}$ bond distances $(d, \AA)$, charges, and sums $\left(\sum\right)$ of QTAIM charges ( $Q$ units of $e$ ), Mayer Sc- $\mathrm{N}_{\mathrm{im}}$ bond indices, and other QTAIM data (atomic units) at the $\mathrm{Sc}-\mathrm{N}_{\mathrm{im}}$ bond critical point: $\rho$ (electron density), $\nabla^{2} \rho$ (electron density Laplacian), $H$ (total energy density), and $\varepsilon$ (ellipticity). $\delta$ is the delocalization index for the $\mathrm{Sc}-\mathrm{N}_{\mathrm{im}}$ bond at the bond critical point. $\Delta E_{\mathrm{BD}}\left(\mathrm{kcal} \mathrm{mol}{ }^{-1}\right)$ is the bond dissociation energy to relaxed fragments, and the values in parentheses are the values for dissociation to non-relaxed ("frozen") fragments, corrected for basis set superposition error (BSSE) effects $\left(1.1\right.$ and $1.0 \mathrm{kcal} \mathrm{mol}^{-1}$ for $1 \mathbf{1} \_\mathbf{E} \_$py and $2 q \_\mathbf{E} \_$py, respectively).

that at $60{ }^{\circ} \mathrm{C}$, the reactions of 25 with pyridine and $\mathrm{MeCCPh}$ are under kinetic control. At $90{ }^{\circ} \mathrm{C}$, the system comes under thermodynamic control, giving quantitative conversion of $\mathbf{2 3}$ to 27 over $7.5 \mathrm{~h}$.

Reaction of cyclometalated 21 with HCCTol to form 26 also proceeded on the NMR tube scale in $\mathrm{C}_{6} \mathrm{D}_{6}$ but at the lower temperature of $80{ }^{\circ} \mathrm{C}$ and within $5 \mathrm{~h}$, suggestive of a different mechanism. Repeating this reaction with DCCTol indicated incorporation of deuterium into the isopropyl methine group of 26, and the NMR spectra showed an $\underline{\mathrm{H}}$ (as opposed to the expected ND) moiety in the product. These observations are consistent with a $\sigma$-bond metathesis reaction as opposed to reforming the transient borylimide, $\mathbf{2 5}$.

DFT Studies. Electronic and Molecular Structure. To gain a full understanding of the similarities and differences between the bonding and reactivity characteristics of borylimido compounds and their isoelectronic arylimido analogues, we carried out a detailed DFT study involving all of the experimental systems discussed above. Three closely related series of quantum chemical models were required to interrogate properly the various aspects. Table 3 summarizes how the imido/amido and $\mathrm{NacNac}{ }^{\mathrm{NMe}_{2}}$ ligand substituents were handled in each case, together with the labeling scheme adopted to help the reader follow the discussion.

In order to extract underlying electronic trends in the absence of significant steric effects and dispersive interactions, the sterically minimized series prefixed "1q" (borylimido systems) or "2q" (arylimido systems) were used in which the imido/amido groups were treated as $\mathrm{NB}(\mathrm{NHCH})_{2}$ and $\mathrm{NPh}$.
The supporting ligand was approximated as ${ }^{\mathrm{Ph}} \mathrm{NacNac}^{\mathrm{NMe}_{2}}$ in which the real 2,6- $\mathrm{C}_{6} \mathrm{H}_{3}{ }^{\mathrm{i}} \mathrm{Pr}_{2}$ group has been replaced with $\mathrm{Ph}$. For mechanistic and thermodynamic studies, two DFT series with labels prefixed as " $Q$ " and " $Q$ *" were used. The " $Q$ " series are identical to the experimental systems, except that the 2,6$\mathrm{C}_{6} \mathrm{H}_{3}{ }^{\mathrm{i}} \mathrm{Pr}_{2}$ substituents of the imido/amido groups are represented by $2,6-\mathrm{C}_{6} \mathrm{H}_{3} \mathrm{Me}_{2}(\mathrm{Xyl})$ : this gives systems which are sterically quite close to the real ones but yet small enough to evaluate for TSs and mechanistic pathways at an appropriate level of DFT. The " $\mathrm{Q}^{*}$ " series have the full experimental substituents and were used to test the full thermodynamic effects of the steric bulk in these very large systems. Details of the calculations are given in the SI. By way of example, the sterically minimized borylimide pyridine adduct $\left({ }^{\mathrm{Ph}} \mathrm{NacNac}^{\mathrm{NMe}_{2}}\right) \mathrm{Sc}\left\{\mathrm{NB}(\mathrm{NHCH})_{2}\right\}($ py) (1q_E_py) and the full model of the experimentally inferred, base-free borylimide $\left(\mathrm{NacNac}^{\mathrm{NMe}_{2}}\right) \mathrm{Sc}\left\{\mathrm{NB}\left(\mathrm{NAr}^{\prime} \mathrm{CH}\right)_{2}\right\} \quad\left(\mathbf{1 Q}^{*}+\mathrm{C}\right)$ are illustrated in Figure 6.

Turning first to the electronic structure of the new scandiumborylimido compounds we compared the $\mathrm{Sc}-\mathrm{N}_{\text {imide }}$ bonding in the model compounds $\left({ }^{\mathrm{Ph}} \mathrm{NacNac}^{\mathrm{NMe}_{2}}\right) \mathrm{Sc}\left\{\mathrm{NB}(\mathrm{NHCH})_{2}\right\}$ (py) (1q_E_py) and $\left({ }^{\mathrm{Ph}_{2}} \mathrm{NacNac}^{\mathrm{NMe}_{2}}\right) \mathrm{Sc}(\mathrm{NPh})(\mathbf{p y})$ (2q_E py). Compound $2 q \mathbf{E}$ py is a model of Chen's ( $\left.\mathrm{NacNac}^{\mathrm{NMe}_{2}}\right) \mathrm{Sc}$ $\left(\mathrm{NAr}^{\prime}\right)(\mathrm{DMAP})(\overrightarrow{\mathbf{1}})$, and $\mathbf{1 q} \mathbf{E} \_$py is a model of the presumed intermediates formed en route (cf. Scheme 4) to the metalated pyridine complexes 23 and 24 . The geometries of $1 \mathbf{1 q} \mathbf{E}$ py (Figure 6) and $\mathbf{2 q} \mathbf{E}$ py are very similar, as expected. Table 4 summarizes key electronic parameters regarding the electronic structures of these systems which we discuss later on. Figure 7 


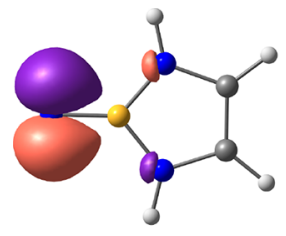

HOMO $\left(\pi_{\mathrm{h}}\right)$

$7.38(6.91) \mathrm{eV}$

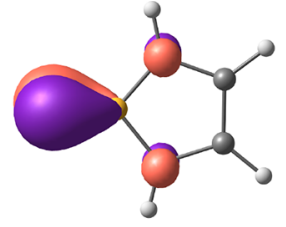

HOMO-1 $\left(\pi_{\mathrm{v}}\right)$

$7.06(6.23) \mathrm{eV}$

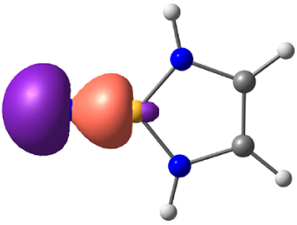

HOMO-2 $(\sigma)$

$5.00(2.99) \mathrm{eV}$

Figure 7. DFT computed $\sigma$ - and $\pi$-type fragment molecular orbitals of the borylimido dianion $\left[\mathrm{NB}(\mathrm{NHCH})_{2}\right]^{2-}$ with the values for $[\mathrm{NPh}]^{2-}$ in parentheses. Calculations were performed in the geometry of the optimized model compounds $\left({ }^{\mathrm{Ph}} \mathrm{NacNac}^{\mathrm{NMe}_{2}}\right) \mathrm{Sc}(\mathrm{NR})(\mathrm{py})\left(\mathrm{R}=\mathrm{NB}(\mathrm{NHCH}){ }_{2}\right.$ (1q_E $\_$py) or $\mathrm{Ph}\left(2 q \_E \_p\right)$. Isosurfaces are drawn at the 0.07465 au contour level.
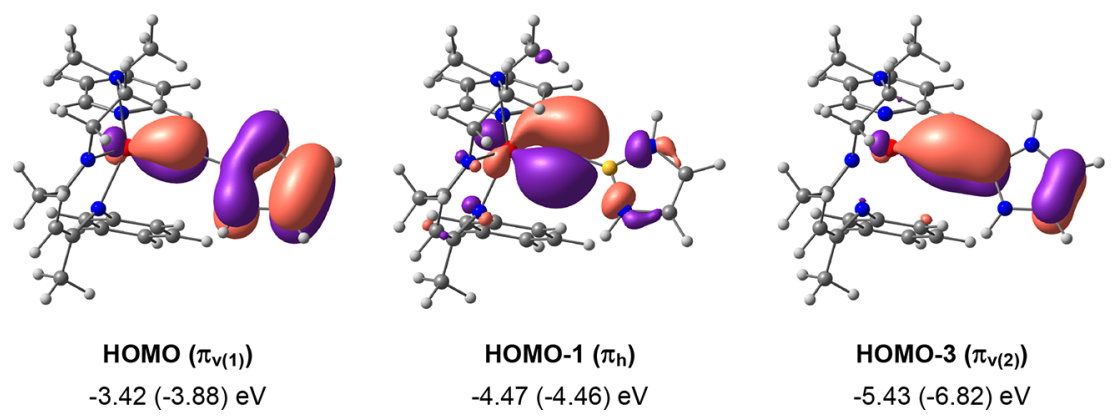

Figure 8. DFT computed $\mathrm{Sc}-\mathrm{N}_{\text {imide }} \pi$-type molecular orbitals of $\left({ }^{\mathrm{Ph}} \mathrm{NacNac}^{\mathrm{NMe}_{2}}\right) \operatorname{Sc}\left\{\mathrm{NB}(\mathrm{NHCH})_{2}\right\}($ py) (1q_E py) with the values for $\left({ }^{\mathrm{Ph}} \mathrm{NacNac}{ }^{\mathrm{NMe}_{2}}\right) \mathrm{Sc}(\mathrm{NPh})(\mathrm{py})\left(2 \mathrm{2} \_\mathbf{E} \_\right.$py) in parentheses. Isosurfaces are drawn at the 0.0360 au contour level.

shows the $\pi$-and $\sigma$-type three highest energy frontier orbitals of the $\left[\mathrm{NB}(\mathrm{NHCH})_{2}\right]^{2-}$ dianion, and Figure 8 shows the $\mathrm{Sc}-\mathrm{N} \pi$ and $\sigma$-bonding molecular orbitals of $1 \mathbf{q} \mathbf{E} \_$py. The $\sigma$ - and $\pi$ type MOs of $[\mathrm{NPh}]^{2-}$ and the frontier $\mathrm{MOs}$ of $2 \mathbf{q}_{\mathbf{E}} \mathbf{E}$ py are given in Figures S6 and S8 of the SI, and their energies are summarized for convenience in Figures 7 and 8, respectively.

The HOMO of $\left[\mathrm{NB}(\mathrm{NHCH})_{2}\right]^{2-}$ is a nitrogen $2 \mathrm{p}$ AO (denoted $\pi_{\mathrm{h}}$ ) lying in the horizontal plane of the $\mathrm{B}(\mathrm{NHCH})_{2}$ ring. The HOMO-1 (denoted $\pi_{\mathrm{v}}$ ) lies in a vertical orientation and is a nitrogen $2 \mathrm{p}$ AO stabilized relative to $\pi_{\mathrm{h}}$ by delocalization to the $2 \mathrm{p}$ AO of boron. However, this latter orbital is also involved in $\pi$-bonding with the two adjacent $\mathrm{N}(\mathrm{H})$ atoms and in $\pi$-bonding within the aromatic $\mathrm{B}(\mathrm{NHCH})_{2}$ ring (cf. Figure S5 of the SI) in general. The electropositive nature of $\mathrm{B}$ makes MOs containing contributions from this element less stable. Therefore, although $\left[\mathrm{NB}(\mathrm{NHCH})_{2}\right]^{2-}$ is isoelectronic with $[\mathrm{NPh}]^{2-}$, the $\mathrm{Ph}$ ring in the latter better stabilizes $\pi_{\mathrm{v}}$ as judged by the larger HOMO-(HOMO-1) separation in $[\mathrm{NPh}]^{2-}(0.68 \mathrm{eV})$ compared to $0.32 \mathrm{eV}$ in $\left[\mathrm{NB}(\mathrm{NHCH})_{2}\right]^{2-}$. Because of the electropositive nature of boron compared to carbon, the average energy of the HOMO and HOMO-1 of the borylimide dianion is $0.65 \mathrm{eV}$ higher (less stable), suggesting that this borylimide is a better $\pi$-donor than phenylimide. This effect is amplified in the HOMO-2 of the anions which are the $\sigma$-donor orbitals. Here the borylimide orbital is ca. $2 \mathrm{eV}$ less stable, suggesting an even greater improvement in $\sigma$-donor ability. This molecular orbital treatment is supported by a Natural Bond Orbital $(\mathrm{NBO})^{31}$ analysis of the anions (Figure S7 of the Supporting Information) which find the same trends in orbital energies, including a greater degree of $\pi_{\mathrm{v}}$ delocalization in $[\mathrm{NPh}]^{2-}$ and more $2 \mathrm{p}$ atomic orbital character in the $\sigma$-donor natural localized molecular orbital (NLMO) of $\left[\mathrm{NB}(\mathrm{NHCH})_{2}\right]^{2-}$.

The $\mathrm{Sc}-\mathrm{N}_{\text {imide }} \pi$-MOs of $\mathbf{1 q} \mathbf{E}$. py shown in Figure 8 (the $\sigma$ bonding counterpart (not shown) is mainly in HOMO-6) are consistent with a $\mathrm{Sc} \equiv \mathrm{N}$ triple bond $\left(\sigma^{2} \pi^{4}\right.$ configuration $)$ as expected. The frontier MOs of $2 \mathbf{2} \_\mathbf{E} \_\mathbf{p y}$ are similar in general terms (Figure S8 of the SI) and resemble those reported by Chen. ${ }^{5}$ The frontier MOs for the borylimide are destabilized relative to these by ca. $0.6 \mathrm{eV}$ on average because of the different properties of the $\mathrm{B}(\mathrm{NHCH})_{2}$ ring. The $\mathrm{Sc}-\mathrm{N} \pi_{\mathrm{v}}$ bonding is distributed between the HOMO and HOMO-3 of 1q_E_py and $2 q \_$E py because of additional $\pi$-interactions (antibonding and bonding, respectively) with the $\mathrm{B}(\mathrm{NHCH})_{2}$ or $\mathrm{Ph}$ rings. The bonding in $\mathbf{1 q} \mathbf{E} \_\mathbf{p y}$ and $\mathbf{2 q} \mathbf{E} \_\mathbf{p y}$ is quite ionic with only ca. $6-12 \% \mathrm{Sc}$ contribution to HOMO, HOMO-1, and HOMO-3 in the Mulliken population analysis.

Further insight into the relative bonding capabilities of the borylimide and arylimide systems was gained from the data summarized in Table 4 which include the results of a quantum theory of atoms in molecules (QTAIM) ${ }^{32}$ analysis of 1q_E $\mathbf{E}$ y and $2 q\left[E \_p y\right.$. These data are again indicative of quite ionic systems, with large QTAIM atomic charges (Q) for Sc and sums of charges $\left(\sum Q\right)$ for the imido and ${ }^{\mathrm{Ph}} \mathrm{NacNac}{ }^{\mathrm{NMe}_{2}}$ ligands. The relative $\sum Q$ values reflect the formally di- and monoanionic nature of the respective groups. The comparatively small magnitudes of the electron density $(\rho)$ and total energy density $(H)$ at the bond critical points (BCPs), and the positive value of the electron density Laplacian $\left(\nabla^{2} \rho\right)$, all imply covalent, very polar bonds. The Mayer bond indices of $1 q\left[E \_\right.$py and $2 q \_$E py are comparable to each other and to the value of 1.56 reported by Mindiola et al. for $\mathrm{Sc}(\mathrm{PNP})$ $\left(\mathrm{NAr}^{\prime}\right)(\mathrm{py}) .{ }^{11 \mathrm{~b}}$ The QTAIM delocalization indices $(\delta$, which relates to the relative bond order for similar atom-pairs) are likewise comparable. The data also point to the $\mathrm{NB}(\mathrm{NHCH})_{2}$ ligand being a stronger donor than $\mathrm{NPh}$. The larger magnitudes of $\rho$ and $H$, and less positive $\nabla^{2} \rho$, demonstrate more covalency in the $\mathrm{Sc}-\mathrm{N}_{\text {imide }}$ bond of $1 \mathbf{q} \mathbf{E}$ py, and the less negative $\sum Q(\mathrm{NR})$ value for $\mathrm{NB}(\mathrm{NHCH})_{2}$ is consistent with this. Note that the reduced $\sum Q(\mathrm{NR})$ value is accompanied by a more negative $\sum Q\left({ }^{\mathrm{Ph}} \mathrm{NacNac}^{\mathrm{NMe}_{2}}\right)$ due to the imido group's 
Scheme 7. DFT Computed Reactions of $\left({ }^{\mathrm{Ph}} \mathrm{NacNac}^{\mathrm{NMe}_{2}}\right) \mathrm{Sc}(\mathrm{Me})\left\{\mathrm{NHB}(\mathrm{NHCH})_{2}\right\}\left(1 \mathrm{q} \_\right.$A) and $\left({ }^{\mathrm{Ph}} \mathrm{NacNac}^{\mathrm{NMe}}\right) \mathrm{Sc}(\mathrm{Me})(\mathrm{NHPh})$ $\left(2 \mathrm{q} A\right.$ ) with Relative Gibbs Free Energies $\left(G_{\text {rel }}, \mathrm{kcal} \mathrm{mol}^{-1}\right)$ at $298.15 \mathrm{~K}$ and $H_{\text {rel }}$ Values in Parentheses ${ }^{a}$<smiles></smiles>

1q_H $-31.2(-42.7)$ 2 q_H $-26.9(-38.2)$

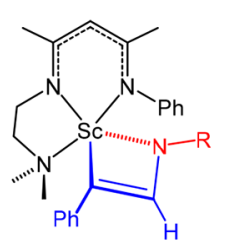

1q_I -30.6 (-45.1) 2q_I-26.8 (-40.9)

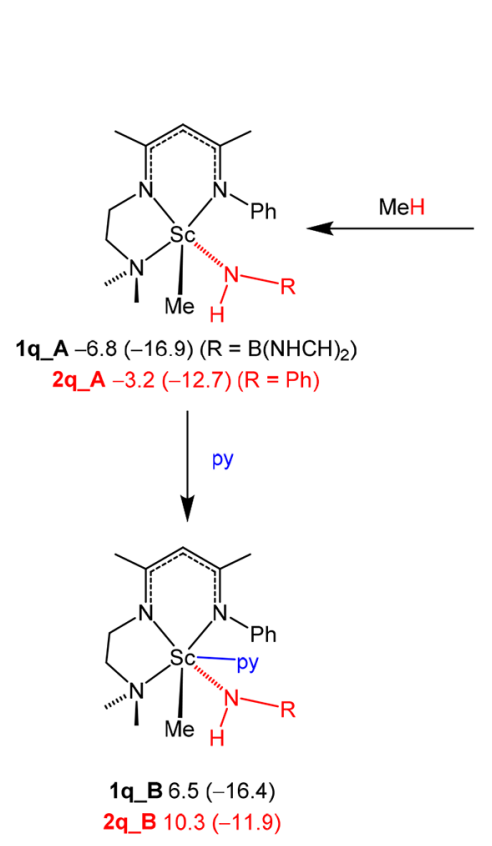<smiles>[R]N=[S-]1(Nc2ccccc2)N(C)CCN2C(C)=CC(C)=NCN21</smiles>

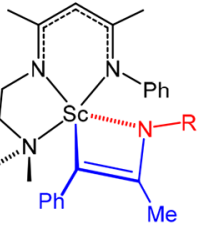
1q_J -18.9 (-36.1) 2q_J-14.0 (-30.8) py or DMAP
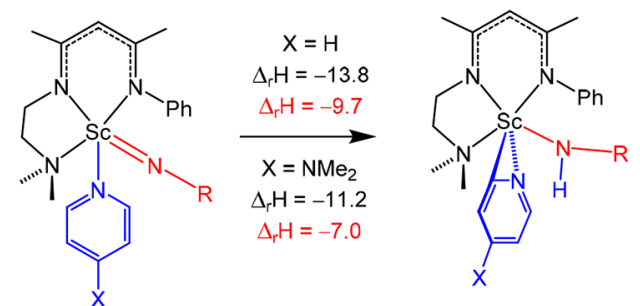

$\mathrm{X}=\mathrm{H}$

1q_E_py $-3.0(-14.5)$

2q_E_py $-4.4(-15.1)$

$\mathrm{X}=\mathrm{NMe}_{2}$

1q_E_DMAP $-5.7(-16.5)$

2q_E_DMAP $-7.5(-17.4)$

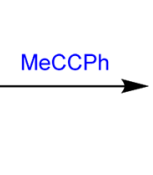

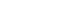


Scheme 8. DFT Computed Reactions of $\left(\mathrm{NacNac}^{\mathrm{NMe}_{2}}\right) \mathrm{Sc}(\mathrm{Me})\left\{\mathrm{NHB}\left(\mathrm{NAr}^{\prime} \mathrm{CH}\right)_{2}\right\}\left(1 Q^{*} \_\right.$A $)$and $\left(\mathrm{NacNac}^{\mathrm{NMe}_{2}}\right) \mathrm{Sc}(\mathrm{Me})\left(\mathrm{NHAr}^{\prime}\right)$ $2 Q^{*} \_$, with $G_{\text {rel }}$ Values $\left(\mathrm{kcal} \mathrm{mol}^{-1}\right)$ at $343.0 \mathrm{~K}^{a}$

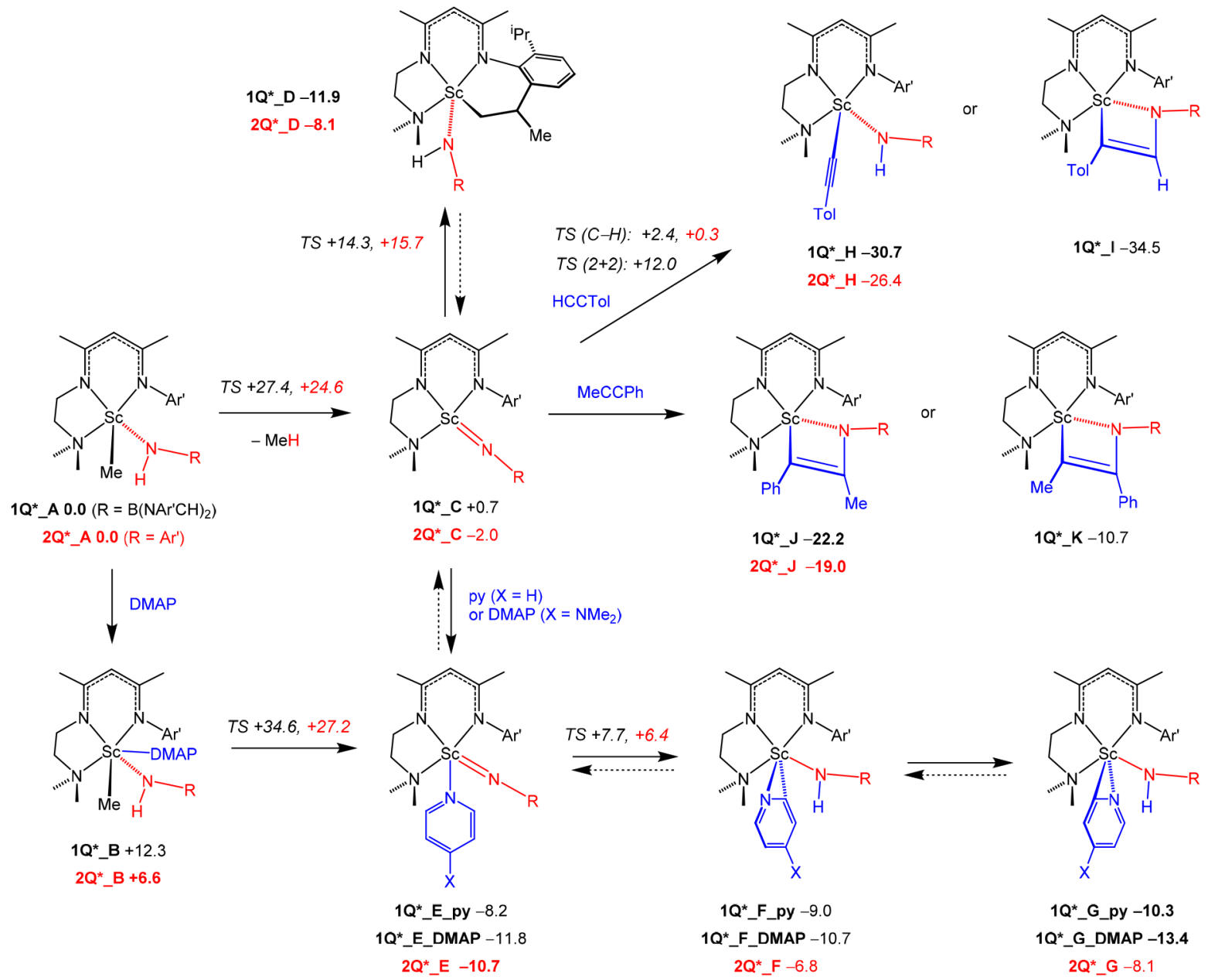

${ }^{a_{T}}$ The numerical values in bold type are for experimentally-observed species. The dotted arrows are for reactions known from experiment to be reversible. The transition state (TS) $G_{\text {rel }}$ values (in italic) are based on the $\Delta G^{\ddagger}$ values for the "Q" series (cf. Scheme S3 in the SI) expressed relative to the energy of $1 Q^{*} \_$A and $2 Q^{*} \_$. Black text is used for $1 Q^{*}$ based systems and red for $2 Q^{*}$.

all three sets to gain a complete picture of the reaction chemistry. Scheme 7 gives good initial insight into the underlying electronic trends of the two types of imido compound in the absence of significant steric or dispersion energy effects. Gibbs free energies are given (with the corresponding enthalpies) relative to the imido compounds 1q_C and 2qC. Note that because the "q" series necessarily uses the sterically minimized ${ }^{\mathrm{Ph}} \mathrm{NacNac}^{\mathrm{NMe}_{2}}$, Scheme 7 is not able to give direct insight into the cyclometalation reactions of the real systems that involve activation of the $\mathrm{Ar}^{\prime}$ group of the experimental $\mathrm{NacNac}^{\mathrm{NMe}_{2}}$ supporting ligand.

For both the borylamide $\mathbf{1 q} \mathbf{A}$ and arylamide $\mathbf{2 q} \mathbf{A}$, methane elimination to form the imido intermediates $n \mathbf{q} C$ $(n=1$ or 2$)$ is both endergonic and endothermic in these model systems. From the imides $n \mathbf{q} \_\mathbf{C}, \mathrm{C}-\mathrm{H}$ bond activation follows the expected thermodynamic trend: sp (most exothermic) $>\mathrm{sp}^{2}>\mathrm{sp}^{3} \cdot{ }^{28 \mathrm{i}}$ For reactions with the model terminal alkyne, $\mathrm{HCCPh}$, formation of $n \mathbf{q} \_\mathbf{H}(\mathrm{C}-\mathrm{H}$ activation) is slightly less exothermic than $n \mathbf{q}_{\mathbf{I}} \mathbf{I}([2+2]$ cycloaddition), in contrast to experimental outcome, although in terms of Gibbs free energy there is little difference. This is in keeping with the experimental and computational trends for reactions of early transition metal imides with terminal alkynes. ${ }^{33}$ As noted for related transition metal systems, ${ }^{34}$ the $[2+2]$ cycloaddition reaction with $\mathrm{MeCCPh}$ to form $n \mathbf{q} \mathrm{J}$ is less exothermic than with $\mathrm{HCCPh}$ due to the electron-releasing methyl group which destabilizes the electron-rich azametallacycle. An important factor that emerges from all of the $\mathrm{C}-\mathrm{H}$ activation or cycloaddition reactions is that those of the borylimide $\mathbf{1 q} \mathbf{C}$ are all more exothermic by between -4.2 and $-5.3 \mathrm{kcal} \mathrm{mol}^{-1}$ compared to the phenylimide $2 q_{\mathcal{C}} \mathrm{C}$, consistent with the $\Delta E_{\mathrm{BD}}$ calculations on $n q$ E py and $\mathrm{H}_{2} \mathrm{NR}\left(\mathrm{R}=\mathrm{B}(\mathrm{NHCH})_{2}\right.$ or $\left.\mathrm{Ph}\right)$.

Pyridine and DMAP involvement and/or activation are important factors in the real experimental systems, and it was important to pay attention to this aspect. There is negligible thermodynamic difference between pyridine coordination to either methyl-amide starting compound $n \mathbf{q}$ A $(\Delta \Delta G=0.2 \mathrm{kcal}$ $\mathrm{mol}^{-1}$ for $n \mathbf{q} \mathbf{A}+$ py $\left.\rightarrow n q \mathbf{B}\right)$, and both reactions are endergonic. In contrast, pyridine addition to the fourcoordinate imides $n \mathbf{n} \_\mathbf{C}$ to give $n \mathbf{q} \_\mathbf{E} \_\mathbf{p y}$ is moderately exergonic, as expected from the lower coordination number. DMAP addition, forming $n q$ E_DMAP, is more favorable than for pyridine as expected. For both $n q \_$E py and $n q \_$E_DMAP, Lewis base addition is less exothermic for the borylimido homologue due to the better donor ability of $\mathrm{NB}(\mathrm{CHCH})_{2}$ compared to $\mathrm{NPh}$. From all four adducts $n \mathbf{q} E$, pyridine or 
DMAP orthometalation ( $\mathrm{C}-\mathrm{H}$ addition) across the $\mathrm{Sc}-\mathrm{N}_{\text {imide }}$ bond is electronically favorable, but less so (i) for DMAP (at least in part because of the stronger bonding in nq E_DMAP) and (ii) for the phenylimides $2 q \_\mathbf{E}$ py and $2 \mathbf{2} \mathbf{E} \_\mathbf{D M A P}$ for the reasons already highlighted above. In terms of electronic preferences, the model systems suggest that formation of 2q_E_DMAP is the most favorable product starting from the methyl-amides $n \mathbf{n} \mathbf{A}$, and least likely to form an orthometalated pyridine derivative $\mathbf{n q} \mathbf{G}$, consistent with experiment.

Scheme 8 shows the computed reactions for the full experimental models $\left(\mathrm{NacNac}^{\mathrm{NMe}_{2}}\right) \mathrm{Sc}(\mathrm{Me})\left\{\mathrm{NHB}\left(\mathrm{NAr}^{\prime} \mathrm{CH}\right)_{2}\right\}$ $\left(1 Q^{*}\right.$ A $)$ and $\left(\mathrm{NacNac}^{\mathrm{NMe}_{2}}\right) \mathrm{Sc}(\mathrm{Me})\left(\mathrm{NHAr}^{\prime}\right)\left(2 \mathbf{Q}^{*}\right.$ A $)$. Gibbs

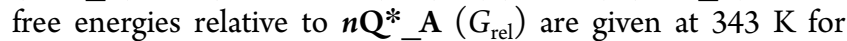
comparison with experiment. The $G_{\text {rel }}$ values in bold type are for experimentally observed species; the dotted arrows are for reactions known to be reversible. Scheme S3 of the SI shows the corresponding data for the intermediate series " $Q$ " for which TS energies could be evaluated for the key reaction steps in most cases. Both schemes generally express the same trends and outcomes, but more accurate ground-state energies (as judged by correlation with experimental outcomes) are found with the full model systems.

The underlying thermodynamic trends in the larger models follow those determined on electronic grounds for the " $q$ " series with respect to activation reactions of the $\mathrm{Sc}-\mathrm{N}_{\text {imide }}$ bonds of the intermediate imides: for example, reactions are consistently more exergonic for the borylimide, and $\mathrm{C}-\mathrm{H}$ activation reactions follow the expected sequence. In the following discussion we focus mainly on the borylimide/ borylamide reactions, drawing attention to the key differences between these and the arylimide where required.

The calculated $\Delta G$ for forming $1 Q^{*} \_$is slightly endergonic despite the positive $\Delta S$ for the elimination reaction $(38.8 \mathrm{cal}$ $\left.\mathrm{mol}^{-1} \mathrm{~K}^{-1}\right)$. The activation energy $\left(\Delta G^{\ddagger}=27.4 \mathrm{kcal} \mathrm{mol}^{-1}\right)$ is in good agreement with that measured experimentally $(26.0 \pm$ $0.1 \mathrm{kcal} \mathrm{mol}^{-1}$ derived from the rate constants in Tables 1 and 2) at the same temperature. The slightly negative entropy of activation $\left(\Delta S^{\ddagger}=-8.8 \mathrm{cal} \mathrm{mol}^{-1} \mathrm{~K}^{-1}\right)$ is due to the rather early (with respect to overall methane elimination) nature of this TS $\left(\mathrm{Sc}-\mathrm{N}_{\text {amide }}\right.$ and $\mathrm{Sc}-\mathrm{C}=1.874$ and $2.400 \AA$ compared to 2.027 and $2.237 \AA$ in $1 \mathrm{Q}$ A). Comparable negative experimental $\Delta S^{\ddagger}$ values have been reported by Wolczanski for loss of alkane from titanium amide-alkyl compounds forming a transient imide. ${ }^{28 \mathrm{a}}$ In addition, the quite linear $\mathrm{N}-\mathrm{H} \cdots \mathrm{C}_{\mathrm{Me}}$ interaction $\left(158.5^{\circ}\right)$, the planar four-center $\mathrm{C}_{\mathrm{Me}}-\mathrm{Ti}-\mathrm{N}-\mathrm{H}$ arrangement, and the similar amounts of $\mathrm{N}-\mathrm{H}$ bond breaking $(\mathrm{N} \cdots \mathrm{H}=1.357$ $\AA$ ) and $\mathrm{C}-\mathrm{H}$ bond making $(\mathrm{C} \cdots \mathrm{H}=1.467 \AA)$, as judged by the bond distances, are all consistent, ${ }^{28 \mathrm{a}, \mathrm{h}, \mathrm{i}, \mathrm{k}}$ with the large primary $\mathrm{KIE}=8.7 \pm 0.5$ observed for the elimination reactions of 18 and $18-d_{1}$. From $1 Q^{*}$ C pyridine or DMAP addition is exergonic, $\Delta G$ for the latter being more negative. The activation $\Delta G^{\ddagger}$ for adduct formation could not be located (the reaction surface being characteristically rather flat) but is expected $^{16,34,35}$ to be low, and certainly in comparison to that which forms the cyclometalated $1 Q^{*}$ D. This, and the rather low $\Delta G^{\ddagger}$ barrier for pyridine orthometalation $(15.9 \mathrm{kcal}$ $\mathrm{mol}^{-1}$ ), is consistent with 23 and 24 being the experimentally observed products (modeled by $1 \mathbf{Q}^{*} \mathbf{G}_{-} \mathbf{p y}$ and 1Q* G DMAP). Experimentally, thermolysis of $\overline{\mathbf{1 8}}$ in the presence of THF formed only $\mathbf{2 1}$. We found that the THF analogue of $1 Q^{*}$ E_py (namely, 1Q*_E_THF, not shown in Scheme 8 ) has $\Delta \bar{G}=-2.7 \mathrm{kcal} \mathrm{mol}^{-1}$ relative to $1 \mathbf{Q}^{*} \_$A at 343
$\mathrm{K}$ (a similar value was found for the "Q" series counterpart 1Q E_THF) and is therefore thermodynamically unstable with respect to forming $1 \mathbf{Q}^{*} \mathbf{D}$ and THF. Although a THF adduct of this type could be kinetically favored, under the reaction conditions required to form the imido intermediate $1 \mathbf{Q}^{*} \mathrm{C}$ $\left(\Delta G^{\ddagger}=27.4 \mathrm{kcal} \mathrm{mol}^{-1}\right.$ from 1Q A), the barrier to forming the cyclometalated product from the THF adduct is only 17.0 $\mathrm{kcal} \mathrm{mol}^{-1}$, explaining why such an adduct is not experimentally observed. An alternative, base-assisted pathway to form 1Q*_E_DMAP from $1 Q^{*}$ A via the adduct $1 Q^{*}$ B was found to have a significantly higher barrier $\left(\Delta G^{\ddagger}=34.6 \mathrm{kcal}\right.$ $\left.\mathrm{mol}^{-1}\right)$. This is consistent with experiment that found the rates of methane elimination from 18 were unaffected by a Lewis base. In contrast, the barriers either with or without DMAP precoordination for methane elimination from $2 Q A^{*}$ to form 2Q*_E_DMAP are more similar, consistent with Chen's observation of DMAP assisted methane elimination. The differences between the reactions of the boryl- and arylamido systems in this case are attributed to steric effects, the required intermediate $n \mathbf{Q}^{*}$ B being $5.7 \mathrm{kcal} \mathrm{mol}^{-1}$ less stable for the borylamide system (in the sterically pruned systems there was no substantial difference in energy for the two methyl-amides nq B). In the absence of added DMAP, thermolysis of Chen's 19 experimentally formed the cyclometalated product 22, consistent with the calculated formation of $2 Q^{*}$ D from $2 Q^{*}$ A.

The pyridine metalation processes modeled by $n \mathbf{Q}^{*} \mathbf{E} \rightarrow$ $n \mathbf{Q}^{*} \mathbf{F} \rightarrow n \mathbf{Q}^{*} \mathbf{G}$ are in good agreement with the experimental observations and the underlying trends already discussed for the small model ("q") systems. The arylimide $2 Q^{*}$ E is stable with respect to $2 Q^{*}$ G, as found experimentally. $2 Q^{*}$ E is also computed to be stable to DMAP elimination to form $2 Q^{*}$ D (even at $90{ }^{\circ} \mathrm{C}$ the process is endergonic $\left(\Delta G=1.6 \mathrm{kcal}^{-} \mathrm{mol}^{-1}\right)$ despite the strong entropic driving force), again in agreement with experiment. Pyridine or DMAP C-H activation (orthometalation) from the borylimide adducts $1 Q^{*}$ E easily form kinetic products $\left(1 \mathbf{Q}^{*} \mathbf{F}\right)$, and subsequent in-place rotation of the metalated ligand (TS too shallow to be located) forms the isomers 1Q*_G. The DFT computed structures of $\left(\mathrm{NacNac}^{\mathrm{NMe}_{2}}\right) \mathrm{Sc}$ $\left\{\eta^{2}(\overline{\mathrm{C}}, \mathrm{N})-\mathrm{NC}_{5} \mathrm{H}_{4}\right\} \quad\left(1 \mathbf{Q}^{*} \_\mathbf{F} \_\right.$py) and $\left(\mathrm{NacNac}^{\mathrm{NMe}_{2}}\right) \mathrm{Sc}-$ $\left\{\eta^{2}(\mathrm{~N}, \mathrm{C})-\mathrm{NC}_{5} \mathrm{H}_{4}\right\} \quad\left(1 \mathrm{Q}^{*} \mathrm{G}_{-}\right.$py) are shown in Figure S9 of the SI, together with selected bond distances. In the former, the anionic carbon of the metalated pyridine is placed trans to one of the anionic donors of the $\mathrm{NacNac}^{\mathrm{NMe}_{2}}$ ligand. Rearrangement allows shortening of two of the $\mathrm{Sc}-\mathrm{N}$ bonds of this supporting ligand and of $\mathrm{Sc}-\mathrm{N}_{\mathrm{py}}$. The very similar energies of $1 \mathbf{Q}^{*} \mathrm{E}$, $1 Q^{*} F$, and $1 Q^{*} G$, and the relatively low barriers between them and the base-free imide $1 Q^{*} \mathbf{C}$ (for example, $G_{\text {rel }}=11.0$ $\mathrm{kcal} \mathrm{mol}^{-1}$ cf. 1Q*_G_py at $343 \mathrm{~K}$ ), account for the facile pyridine exchange reactions found experimentally (Scheme 4).

Experimentally, formation of $\mathbf{2 3}$ and $\mathbf{2 4}$ is kinetically favored compared to cyclometalation to give 21 in the thermolysis reactions of 18 at $60{ }^{\circ} \mathrm{C}$. However, at $90{ }^{\circ} \mathrm{C}$, conversion to 21 and pyridine is observed for 23 but not for $\mathbf{2 4}$. The calculations are consistent with this being a process under thermodynamic control at this temperature $\left(\Delta G_{363 \mathrm{~K}}=-1.6\right.$ and $+1.5 \mathrm{kcal}$ $\mathrm{mol}^{-1}$ respectively for $1 Q^{*} \mathbf{G}_{\text {_ }}$ py or $1 \mathbf{Q}^{*} \mathbf{G}_{-}$DMAP $\rightarrow$ $1 Q^{*}$ D). This reaction is strongly endothermic $\overline{(} \Delta H=12.7$

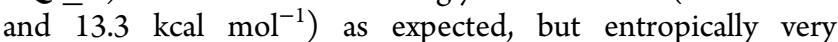
favorable. The overall activation $\Delta G^{\ddagger}$ for formation of 1Q D and pyridine (relative to $\mathbf{1 Q} \mathbf{G} \_$py) is $24.9 \mathrm{kcal} \mathrm{mol}^{-1}$. 
Experimentally, with respect to the reactions with alkynes (Scheme 6), thermolysis of $\mathbf{1 8}$ forms only the $\mathrm{C}-\mathrm{H}$ activation product 26 with HCCTol, and the [2+2] cycloaddition product 27 (one isomer only) with $\mathrm{MeCCPh}$. No rate differences were found with DCCTol. These products are modeled by $1 \mathbf{Q}^{*} \mathbf{H}$ and $1 Q^{*} \mathrm{~J}$ for the full DFT systems and $1 \mathbf{Q} \mathbf{H}$ and $1 \mathbf{Q ~ J}$ for the intermediate steric bulk models. An alternative $[2+2]$ cycloaddition product (modeled by $1 \mathbf{Q}^{*}$ I in Scheme 8) was not observed in the reaction with HCCTol. Thermolysis of $\mathbf{2 1}$ at $100{ }^{\circ} \mathrm{C}$ in the presence of $\mathrm{MeCCPh}$ formed 27. Therefore, although $\mathbf{2 1}$ is the final thermodynamic product (at least at elevated temperatures) in the reactions with pyridine, with alkynes the $\mathrm{C}-\mathrm{H}$ activation or $[2+2]$ cycloaddition products appear to be the thermodynamic products.

The DFT results, in full agreement with experiment, offer insights into these observations. Activation of the sp hybridized $\mathrm{C}-\mathrm{H}$ bond of HCCTol $\left(\Delta G=-31.4 \mathrm{kcal} \mathrm{mol}^{-1}\right.$ at $343 \mathrm{~K}$ for forming $1 Q^{*}{ }_{-} H_{\text {from }} 1 Q^{*}$ C) is strongly thermodynamically preferred to $\mathrm{sp}^{3} \mathrm{C}-\mathrm{H}$ bond activation on electronic grounds (as discussed for the model systems "q") despite being entropically less favorable. The TS for this process is also lower for the alkyne reaction than for cyclometalation $\left(\Delta \Delta G^{\ddagger}\right.$ ca. $12 \mathrm{kcal} \mathrm{mol}^{-1}$ ), consistent with methane-elimination being the rate-determining step in all cases. $\Delta G^{\ddagger}$ for re-forming the imido intermediate $1 Q^{*} \mathbf{C}$ from $1 Q^{*} \mathbf{D}$ is $26.2 \mathrm{kcal} \mathrm{mol}^{-1}$ at $343 \mathrm{~K}$ consistent with the reversibility observed experimentally. Interestingly, the observed $\mathrm{C}-\mathrm{H}$ bond activation product $\mathbf{2 6}$ (as modeled by $1 \mathbf{Q}^{*} \mathbf{H}$ ) is not the thermodynamic product. Instead the $[2+2]$ cycloaddition species $1 \mathbf{Q}^{*} \mathbf{I}$ is the most stable isomer by ca. $4 \mathrm{kcal} \mathrm{mol}^{-1}$ (as found for the small model systems $\mathbf{1 q} \mathbf{H}$ and $\mathbf{1 q} \mathbf{I}$, in terms of enthalpic (electronic) preferences). The formation of $\mathbf{2 6}$ is therefore under kinetic control as confirmed by the higher TS for formation of $1 \mathbf{Q}$ I compared to $1 \mathrm{Q} \mathrm{H}\left(\Delta \Delta G^{\ddagger}=9.6 \mathrm{kcal} \mathrm{mol}^{-1}\right.$ at $\left.343 \mathrm{~K}\right)$. The high stability of $1 \mathbf{Q}^{*} \mathbf{H}$ compared to the base-free imide 1Q*C and HCCTol $\left(\Delta G=31.4 \mathrm{kcal} \mathrm{mol}^{-1}\right.$ at $343 \mathrm{~K}$ for the alkyne elimination process) ensures that, even at elevated temperatures, 26 remains the only product formed.

The DFT compound $1 \mathbf{Q}^{*} \mathrm{~J}$ (model for 27 ) is $\mathrm{ca} .11 \mathrm{kcal}$ $\mathrm{mol}^{-1}$ less stable than $1 Q^{*} \overrightarrow{\mathrm{I}}$, consistent with factors already discussed for $\mathbf{1 q} \mathbf{J}$ and $\mathbf{1 q} \bar{I}_{\mathbf{I}}$. An alternative isomer $\left(1 \mathbf{Q}^{*} \mathbf{K}\right)$ with the cycloaddition occurring in the opposite sense is less stable than $1 \mathbf{Q}^{*} \mathrm{~J}$. In imidotitanium chemistry, for example, this same preference is attributed to the ability of the aryl group to better stabilize the negative charge accumulated on the metal-bound metallacycle carbon. ${ }^{34}$

We were not able to locate computationally the TS leading to $1 Q^{*} \mathrm{~J}$ but its energy can be estimated as being higher by at least $2-3 \mathrm{kcal} \mathrm{mol}^{-1}$ than that for $1 \mathbf{Q}^{*} \mathbf{H}_{\mathbf{H}}$ because, experimentally, a 1:5:5 competition reaction between 18 and HCCTol and MeCCPh gave exclusively 26. On the other hand, the cycloaddition TS is probably lower in energy than that leading from the base-free imide to $\mathbf{2 1}$ since none of the cyclometalated compound is formed on thermolysis of $\mathbf{1 8}$ with $\mathrm{MeCCPh}$ and 21 only reacts back with $\mathrm{MeCCPh}$ to form 27 at $90{ }^{\circ} \mathrm{C}$. These experimentally guided estimates are broadly consistent with $\Delta G^{\ddagger}$ calculated for the $[2+2]$ cycloaddition reaction of HCCTol (11.3 kcal mol $\mathrm{H}^{-1}$ at $\left.343 \mathrm{~K}\right)$. A barrier of this magnitude would be also consistent with the observation that $\mathbf{2 7}$ does not react even under thermally forcing conditions with HCCTol to give the thermodynamically preferred $\mathbf{2 6}$.

\section{CONCLUSIONS}

We have presented comprehensive evidence for the formation of the first rare earth metal borylimido complex, namely $\left(\mathrm{NacNac}^{\mathrm{NMe}_{2}}\right) \mathrm{Sc}\left\{\mathrm{NB}\left(\mathrm{NAr}{ }^{\prime} \mathrm{CH}\right)_{2}\right\} \quad$ (25), and have studied its bonding and substrate activation reactions through detailed kinetic and computational analysis. Compound $\mathbf{2 5}$ was readily generated in situ from the methyl-borylamide ( $\left.\mathrm{NacNac}^{\mathrm{NMe}_{2}}\right)$ $\mathrm{Sc}(\mathrm{Me})\left\{\mathrm{NHB}\left(\mathrm{NAr}^{\prime} \mathrm{CH}\right)_{2}\right\}$ (18). Reactions of the related methyl-borylamide $\left(\mathrm{NacNac}^{\mathrm{NMe}_{2}}\right) \mathrm{Sc}(\mathrm{Me})\left\{\mathrm{NHB}\left(\mathrm{N}^{\mathrm{i}} \mathrm{Pr}\right)_{2} \mathrm{C}_{6} \mathrm{H}_{4}\right\}$ (15) were poorly controlled, leading to complex mixtures of products. Thermolysis reactions of $\mathbf{1 8}$ in the absence of external substrate gave intramolecular $\mathrm{sp}^{3} \mathrm{C}-\mathrm{H}$ bond activation of an isopropyl group forming the cyclometalated complex $\{\mathrm{MeC}$ $\left.\left(\mathrm{NC}_{6} \mathrm{H}_{3}{ }^{\mathrm{i}} \mathrm{PrCH}(\mathrm{Me}) \mathrm{CH}_{2}\right) \mathrm{CHC}(\mathrm{Me}) \mathrm{NCH}_{2} \mathrm{CH}_{2} \mathrm{NMe}_{2}\right\} \mathrm{Sc}-$ $\left\{\mathrm{NHB}\left(\mathrm{NAr}^{\prime} \mathrm{CH}\right)_{2}\right\}$ (21). Thermolysis in the presence of pyridine or DMAP formed the pyridyl-type complexes $\left(\mathrm{NacNac}^{\mathrm{NMe}_{2}}\right) \mathrm{Sc}\left\{\mathrm{NHB}\left(\mathrm{NAr}{ }^{\prime} \mathrm{CH}\right)_{2}\right\}\left(\eta^{2}-4-\mathrm{NC}_{5} \mathrm{H}_{3} \mathrm{R}\right) \quad(\mathrm{R}=\mathrm{H}$ (23), $\mathrm{NMe}_{2}(24)$ ), by $\mathrm{sp}^{2} \mathrm{C}-\mathrm{H}$ bond activation at the 2position of coordinated pyridine or DMAP, respectively. Kinetic analysis showed that all of these share a common rate-determining step: initial $\alpha$-abstraction to release methane and generate the transient borylimido complex $\left(\mathrm{NacNac}^{\mathrm{NMe}_{2}}\right)$ $\mathrm{Sc}\left\{\mathrm{NB}\left(\mathrm{NAr} \mathrm{CH}^{\prime} \mathrm{C}\right)_{2}\right.$ (25). Following this step, the respective $\mathrm{C}-\mathrm{H}$ bond activations are rapid. This mechanism was supported by isotope labeling studies.

Compound $\mathbf{2 5}$ undergoes trapping reactions with alkynes. Thus, thermolysis of $\mathbf{1 8}$ in the presence of HCCTol produced the acetylido complex $\left(\mathrm{NacNac}^{\mathrm{NMe}_{2}}\right) \mathrm{Sc}\left\{\mathrm{NHB}\left(\mathrm{NAr}{ }^{\prime} \mathrm{CH}\right)_{2}\right\}$ (CCTol) (26) via $\mathrm{C}-\mathrm{H}$ bond activation at the sp center, and in the presence of the internal alkyne $\mathrm{MeCCPh}$ formed the azascandacyclobutene complex $\left(\mathrm{NacNac}^{\mathrm{NMe}_{2}}\right) \mathrm{Sc}\{\mathrm{N}\{\mathrm{B}$ $\left.\left.\left(\mathrm{NAr}{ }^{\prime} \mathrm{CH}\right)_{2}\right\} \mathrm{C}(\mathrm{Me}) \mathrm{C}(\mathrm{Ph})\right\}(27)$ by $[2+2]$ cycloaddition across the $\mathrm{Sc}-\mathrm{N}_{\text {imide }}$ multiple bond of 25, thus giving excellent evidence for its existence. The first-order rate constants of these two reactions were found to be comparable to those described previously, so confirming the common rate-determining step.

A combined DFT and QTAIM study on model scandium alkylimides and borylimides confirmed that borylimides are expected to be comparable to arylimides structurally, due to the similar $\pi$ effects arising from the aryl ring, and aromatic boryl ring. However, scandium borylimides are calculated to have stronger scandium-nitrogen multiple bonds than their arylimido counterparts due to the strong $\sigma$ - and $\pi$-donating nature of the borylimido ligand. DFT calculations performed on the reaction products of a model base-free borylimide, and its arylimido counterpart, with a number of substrates resulted in an analysis of the relative energetics of these processes. It was shown that $\mathrm{C}-\mathrm{H}$ bond activations are more favorable in the borylimido case, due to the higher strength of the $\mathrm{N}-\mathrm{H}$ bond formed from a borylimido ligand compared with an arylimido ligand. Other bonds formed to a borylimido fragment, such as the $\mathrm{C}-\mathrm{N}$ bond in the metallacyclic product of a $[2+2]$ cycloaddition, are also found to be stronger than those to arylimido fragments, as shown by the more favorable enthalpic contribution to free energy of the process in which it is formed.

Overall, these first detailed computational and experimental studies of borylimido systems indicate the potential for enhanced reactivity compared to their arylimido analogues, and the synthetic metholodogy developed here should be useful for developing borylimido chemistry of early transition metals, as well as other rare earth metal complexes. Further studies are currently underway in our laboratory. 


\section{GENERAL METHODS AND INSTRUMENTATION}

All manipulations were carried out using standard Schlenk line or drybox techniques under an atmosphere of argon or dinitrogen. Solvents were either degassed by sparging with dinitrogen and dried by passing through a column of the appropriate drying agent ${ }^{36}$ or refluxed over sodium (toluene), potassium (THF), $\mathrm{Na} / \mathrm{K}$ alloy $\left(\mathrm{Et}_{2} \mathrm{O}\right)$, or $\mathrm{CaH}_{2}$ (pyridine) and distilled. Deuterated solvents were dried over potassium $\left(\mathrm{C}_{6} \mathrm{D}_{6}\right)$ or $\mathrm{CaH}_{2}$ (pyridine- $\left.d_{5}\right)$, distilled under reduced pressure, and stored under argon in Teflon valve ampules. Unless otherwise stated, NMR samples were prepared under dinitrogen in 5 $\mathrm{mm}$ Wilmad 507-PP tubes fitted with J. Young Teflon valves. ${ }^{1} \mathrm{H}$, ${ }^{13} \mathrm{C}\left\{{ }^{1} \mathrm{H}\right\},{ }^{11} \mathrm{~B}\left\{{ }^{1} \mathrm{H}\right\}$, and ${ }^{2} \mathrm{H}$ spectra were recorded on a Bruker Ascend 400 NMR spectrometer, a Bruker Avance III 500 NMR spectrometer or on a Bruker AVC 500 spectrometer fitted with a ${ }^{13} \mathrm{C}$ cryoprobe. Unless otherwise stated, all NMR spectra were recorded at $298 \mathrm{~K} .{ }^{1} \mathrm{H}$ and ${ }^{13} \mathrm{C}\left\{{ }^{1} \mathrm{H}\right\}$ spectra were referenced internally to residual protiosolvent $\left({ }^{1} \mathrm{H}\right)$ or solvent $\left({ }^{13} \mathrm{C}\right)$ resonances and are reported relative to tetramethylsilane $(\delta=0 \mathrm{ppm}) .{ }^{2} \mathrm{H}$ NMR spectra were referenced to the natural abundance deuterium resonance of the protio solvent. ${ }^{11} \mathrm{~B}$ NMR spectra were referenced externally to $\mathrm{Et}_{2} \mathrm{O} \cdot \mathrm{BF}_{3}$ respectively. Assignments were confirmed as necessary with the use of twodimensional ${ }^{1} \mathrm{H}-{ }^{1} \mathrm{H}$ and ${ }^{13} \mathrm{C}-{ }^{1} \mathrm{H}$ correlation experiments. Chemical shifts are quoted in $\delta$ (ppm) and coupling constants in Hz. Unless otherwise stated, IR spectra were recorded on a Thermo Scientific Nicolet iS5 FTIR spectrometer and samples prepared in a drybox using $\mathrm{NaCl}$ plates as a Nujol mull. The data are quoted in wavenumbers $\left(\mathrm{cm}^{-1}\right)$. Mass spectra were recorded by the mass spectrometry service of Oxford University's Department of Chemistry. Elemental analyses were carried out by the Elemental Analysis Service at the London Metropolitan University.

Representative syntheses are given below. Further details are given in the Supporting Information for the syntheses and characterization of $\mathrm{H}_{2} \mathrm{NB}\left(\mathrm{N}^{\mathrm{i} P r}\right){ }_{2} \mathrm{C}_{6} \mathrm{H}_{4} \quad(11),\left(\mathrm{NacNac}^{\mathrm{NMe}_{2}}\right) \mathrm{Sc}(\mathrm{Me})\{\mathrm{NHB}-$ $\left.\left(\mathrm{N}^{\mathrm{i} P r}\right)_{2} \mathrm{C}_{6} \mathrm{H}_{4}\right\} \quad$ (15), $\left(\mathrm{NacNac}^{\mathrm{NMe}_{2}}\right) \mathrm{Sc}\left\{\mathrm{NHB}\left(\mathrm{N}^{\mathrm{i} P r}\right)_{2} \mathrm{C}_{6} \mathrm{H}_{4}\right\}_{2} \quad$ (16), $\left(\mathrm{NacNac}^{\mathrm{NMe}_{2}}\right) \mathrm{Sc}(\mathrm{Me})\left\{\mathrm{NDB}\left(\mathrm{NAr}{ }^{\prime} \mathrm{CH}\right)_{2}\right\}\left(\mathbf{1 8}-\boldsymbol{d}_{1}\right)$, and $\left(\mathrm{NacNac}^{\mathrm{NMe}_{2}}\right)-$ $\mathrm{Sc}\left\{\mathrm{NHB}\left(\mathrm{NAr}{ }^{\prime} \mathrm{CH}\right)_{2}\right\}\left(\eta^{2}-4-\mathrm{NC}_{5} \mathrm{H}_{3} \mathrm{NMe}_{2}\right)$ (24).

$\left(\mathrm{NacNac} \mathrm{NMe}_{2}\right) \mathrm{Sc}(\mathrm{Me})\left\{\mathrm{NHB}\left(\mathrm{NAr} \mathbf{C}^{\prime} \mathrm{CH}\right)_{2}\right\}$ (18). To a solution of $\left(\mathrm{NacNac}^{\mathrm{NMe}_{2}}\right) \mathrm{ScCl}_{2}(13,0.950 \mathrm{~g}, 2.14 \mathrm{mmol})$ in THF $(25 \mathrm{~mL})$ at $-78{ }^{\circ} \mathrm{C}$ was added $\mathrm{MeLi}\left(1.6 \mathrm{M}\right.$ in $\mathrm{Et}_{2} \mathrm{O}, 2.7 \mathrm{~mL}, 4.28 \mathrm{mmol}$ ). The mixture was allowed to warm to room temperature, then stirred for 4 $h$. The volatiles were then removed under reduced pressure, and the residue was extracted with toluene $(25 \mathrm{~mL})$. The extracts were transferred into a Schlenk tube containing $\mathrm{H}_{2} \mathrm{NB}\left(\mathrm{NAr}{ }^{\prime} \mathrm{CH}\right)_{2}$ (12, $0.862 \mathrm{~g}, 2.14 \mathrm{mmol}$ ), and this mixture was stirred for $60 \mathrm{~h}$ at room temperature. After this time, the volatiles were removed under reduced pressure, and the resulting waxy solid was triturated in hexane $(5 \mathrm{~mL})$. After drying in vacuo, $\mathbf{1 8}$ was isolated as an off-white powder. Yield: $0.898 \mathrm{~g}(53 \%)$. Diffraction-quality crystals were grown from a benzene solution at room temperature. ${ }^{1} \mathrm{H}$ NMR $\left(\mathrm{C}_{6} \mathrm{D}_{6}, 400.1 \mathrm{MHz}\right): \delta 7.18(6$ $\mathrm{H}$, overlapping $2 \times \mathrm{m}$, boryl $m$ - and $\left.p-\mathrm{C}_{6} \underline{\mathrm{H}}_{3}{ }^{\mathrm{i}} \mathrm{Pr}_{2}\right), 7.13\left(2 \mathrm{H}, \mathrm{d},{ }^{3} J=4.6\right.$ $\left.\mathrm{Hz}, \mathrm{NacNac} m-\mathrm{C}_{6} \underline{\mathrm{H}}_{3}{ }^{\mathrm{i}} \mathrm{Pr}_{2}\right), 7.05\left(1 \mathrm{H}, \mathrm{t},{ }^{3} \mathrm{~J}=4.6 \mathrm{~Hz}\right.$, NacNac $p-$ $\left.\mathrm{C}_{6} \underline{\mathrm{H}}_{3}{ }^{\mathrm{i}} \mathrm{Pr}_{2}\right), 6.05(2 \mathrm{H}, \mathrm{s}, \mathrm{NCH}), 4.77(1 \mathrm{H}, \mathrm{s}, \mathrm{MeC}(\mathrm{N}) \mathrm{C} \underline{\mathrm{H}}), 3.70(2 \mathrm{H}$, sept., ${ }^{3} \mathrm{~J}=6.9 \mathrm{~Hz}$, boryl $\left.\mathrm{C}_{\mathrm{a}} \mathrm{MeMe}\right), 3.51\left(2 \mathrm{H}\right.$, sept., ${ }^{3} \mathrm{~J}=6.9 \mathrm{~Hz}$, boryl $\left.\underline{\mathrm{C}}_{b} \mathrm{MeMe}\right), 3.43\left(1 \mathrm{H}\right.$, sept., ${ }^{3} \mathrm{~J}=6.8 \mathrm{~Hz}$, NacNac $\left.\mathrm{CH}_{2} \mathrm{MeMe}\right)$, $3.29(1 \mathrm{H}, \mathrm{s}, \mathrm{NH}), 2.86\left(1 \mathrm{H}\right.$, sept., $\left.{ }^{3} \mathrm{~J}=6.8 \mathrm{~Hz}, \mathrm{NacNac} \mathrm{C}_{\mathrm{b}} \mathrm{MeMe}\right)$, $2.63\left(1 \mathrm{H}, \mathrm{m}, \mathrm{CH}_{2} \mathrm{NC}(\mathrm{Me})\right), 2.53\left(1 \mathrm{H}, \mathrm{m}, \mathrm{CH}_{2} \mathrm{NMe}_{2}\right), 2.44(1 \mathrm{H}, \mathrm{m}$, $\left.\mathrm{C}_{2} \mathrm{NC}(\mathrm{Me})\right), 2.31\left(3 \mathrm{H}, \mathrm{s}, \mathrm{NMe}_{2}\right), 1.98\left(3 \mathrm{H}, \mathrm{s}, \mathrm{NMe}_{2}\right), 1.77(1 \mathrm{H}$, $\left.\mathrm{m}, \mathrm{C}_{2} \mathrm{NMe}_{2}\right), 1.59(3 \mathrm{H}, \mathrm{s}, \underline{\mathrm{MeC}}(\mathrm{N}) \mathrm{CH}), 1.52(3 \mathrm{H}, \mathrm{s}$, $\underline{\mathrm{MeC}}(\mathrm{N}) \mathrm{CH}), 1.42\left(6 \mathrm{H}, \mathrm{d},{ }^{3} \mathrm{~J}=6.9 \mathrm{~Hz}\right.$, boryl CHMe $\left.\mathrm{Me}\right), 1.33(6$ $\mathrm{H}, \mathrm{d},{ }^{3} \mathrm{~J}=6.9 \mathrm{~Hz}$, boryl CHMe $\left.\mathrm{e}_{\mathrm{b}} \mathrm{Me}\right), 1.30(9 \mathrm{H}$, overlapping $2 \times \mathrm{d}$, boryl $\mathrm{CHMeMe}_{b}$ and $\left.\mathrm{NacNac} \mathrm{CHMe}_{\mathrm{a}} \mathrm{Me}\right), 1.23(9 \mathrm{H}$, overlapping $2 \times \mathrm{d}$,

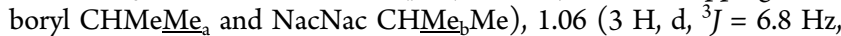
$\mathrm{NacNac} \mathrm{CHMeMe}$ ), $1.04\left(3 \mathrm{H}, \mathrm{d},{ }^{3} J=6.8 \mathrm{~Hz}, \mathrm{NacNac} \mathrm{CHMeMe}_{\mathrm{a}}\right)$, - 0.90 (3 H, s, ScMe) ppm. ${ }^{13} \mathrm{C}\left\{{ }^{1} \mathrm{H}\right\}$ NMR $\left(\mathrm{C}_{6} \mathrm{D}_{6}, 100.6 \mathrm{MHz}\right): \delta$ $166.3(\mathrm{Me} \underline{\mathrm{C}}(\mathrm{N}) \mathrm{CH}), 165.5(\mathrm{Me} \underline{\mathrm{C}}(\mathrm{N}) \mathrm{CH}), 147.5$ (NacNac o$\mathrm{C}_{6} \mathrm{H}_{3}{ }^{\mathrm{i}} \mathrm{Pr}_{2}$ ), 147.4 (boryl o- $\underline{\mathrm{C}}_{6} \mathrm{H}_{3}{ }^{\mathrm{i}} \mathrm{Pr}_{2}$ ), 146.9 (boryl o- $\underline{\mathrm{C}}_{6} \mathrm{H}_{3}{ }^{\mathrm{i}} \mathrm{Pr}_{2}$ ), 142.9 (NacNac $i-\mathrm{C}_{6} \mathrm{H}_{3}{ }^{\mathrm{i}} \mathrm{Pr}_{2}$ ), 141.9 (boryl $i-\mathrm{C}_{6} \mathrm{H}_{3}{ }^{\mathrm{i}} \mathrm{Pr}_{2}$ ), 141.3 (boryl $i-$ $\underline{\mathrm{C}}_{6} \mathrm{H}_{3}{ }^{\mathrm{i}} \mathrm{Pr}_{2}$ ), 126.7 (boryl $p-\mathrm{C}_{6} \mathrm{H}_{3}{ }^{\mathrm{i}} \mathrm{Pr}_{2}$ ), 125.6 (NacNac $p-\underline{\mathrm{C}}_{6} \mathrm{H}_{3}{ }^{\mathrm{i}} \mathrm{Pr}_{2}$ ), 124.1 (NacNac $m-\underline{C}_{6} \mathrm{H}_{3}{ }^{\mathrm{i}} \mathrm{Pr}_{2}$ ), 124.0 (boryl $m-\underline{\mathrm{C}}_{6} \mathrm{H}_{3}{ }^{\mathrm{i}} \mathrm{Pr}_{2}$ ), 123.6 (boryl
$\left.m-\underline{\mathrm{C}}_{6} \mathrm{H}_{3}{ }^{\mathrm{i}} \mathrm{Pr}_{2}\right), 117.5(\mathrm{NCH}), 99.5(\mathrm{MeC}(\mathrm{N}) \underline{\mathrm{CH}}), 58.8\left(\underline{\mathrm{CH}}_{2} \mathrm{NMe}_{2}\right)$, $48.2\left(\mathrm{NMe}_{2}\right), 46.8\left(\mathrm{CH}_{2} \mathrm{NC}(\mathrm{Me})\right), 42.7\left(\mathrm{NMe}_{2}\right), 29.0$ (boryl $\underline{\mathrm{C}}_{\mathrm{a}} \mathrm{HMeMe}$ ), 28.3 (NacNac $\underline{\mathrm{C}}_{b} \mathrm{HMeMe}$ ), 28.2 (boryl $\underline{\mathrm{C}}_{b} \mathrm{HMeMe}$ ), 28.1 (NacNac $\underline{\mathrm{C}}_{\mathrm{a}} \mathrm{HMeMe}$ ), 26.1 (boryl $\mathrm{CHMeMe}$ ), 25.9 (boryl $\mathrm{CHMeMe}$ ), $25.0\left(\mathrm{NacNac} \mathrm{CHMe}_{\mathrm{a}} \mathrm{Me}\right), 24.8(\underline{\mathrm{MeC}}(\mathrm{N}) \mathrm{CH}), 24.7$ ( NacNac CHMeMe $\left.e_{b}\right), 24.4\left(\mathrm{NacNac} \mathrm{CHMe}_{b} \mathrm{Me}\right), 24.3$ (ScMe), 24.2

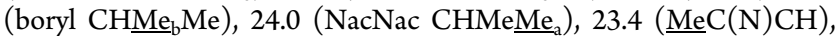
22.8 (boryl CHMe $\mathrm{Me}$ ) ppm. ${ }^{11} \mathrm{~B}\left\{{ }^{1} \mathrm{H}\right\} \mathrm{NMR}\left(\mathrm{C}_{6} \mathrm{D}_{6}, 128.4 \mathrm{MHz}\right): \delta$ 23.3 ppm. IR ( $\mathrm{NaCl}$ plates, Nujol mull, $\left.\mathrm{cm}^{-1}\right): 3212(\mathrm{w}, \mathrm{N}-\mathrm{H}), 3056$ (w), $1930(\mathrm{w}), 1863(\mathrm{w}), 1581(\mathrm{w}), 1546(\mathrm{~m}), 1523(\mathrm{~s}), 1497(\mathrm{~m})$, 1416 (s), 1359 (s), 1345 (s), $1317(\mathrm{~m}), 1254(\mathrm{~m}), 1180(\mathrm{~m}), 1138$ $(\mathrm{w}), 1115(\mathrm{w}), 1103(\mathrm{w}), 1067(\mathrm{w}), 1052(\mathrm{w}), 1024(\mathrm{~m}), 962(\mathrm{w})$, $937(\mathrm{~m}), 878(\mathrm{w}), 845(\mathrm{w}), 806(\mathrm{w}), 790(\mathrm{~m}), 766(\mathrm{~m}), 750(\mathrm{~s}), 706$ $(\mathrm{w}), 649(\mathrm{~m})$. Anal. Found (calcd) for $\mathrm{C}_{48} \mathrm{H}_{74} \mathrm{BN}_{6} \mathrm{Sc}$ : C, 72.68 (72.89); H, 9.55 (9.43); N, 10.50 (10.63)\%.

$\left\{\mathrm{MeC}\left(\mathrm{NC}_{6} \mathrm{H}_{3}{ }^{\mathrm{i}} \mathrm{PrCH}(\mathrm{Me}) \mathrm{CH}_{2}\right) \mathrm{CHC}(\mathrm{Me}) \mathrm{NCH}_{2} \mathrm{CH}_{2} \mathrm{NMe}_{2}\right\} \mathrm{Sc}\{\mathrm{NHB}-$ $\left(\mathrm{NAr}^{\prime} \mathrm{CH}\right)_{2}$ \} (21). A toluene solution $(7.5 \mathrm{~mL})$ of $\left(\mathrm{NacNac}^{\mathrm{NMe}_{2}}\right) \mathrm{Sc}$ $(\mathrm{Me})\left\{\mathrm{NHB}\left(\mathrm{NAr}{ }^{\prime} \mathrm{CH}\right)_{2}\right\}(\mathbf{1 8}, 0.197 \mathrm{~g}, 0.249 \mathrm{mmol})$ was heated at 60 ${ }^{\circ} \mathrm{C}$ for $16 \mathrm{~h}$. The volatiles were removed under reduced pressure, and the resulting residue was washed with hexane $(2 \times 2 \mathrm{~mL})$ to afford 21 as an off-white powder. Yield: $0.100 \mathrm{~g}$ (52\%). Diffraction-quality crystals were grown from a benzene solution at room temperature. ${ }^{1} \mathrm{H}$ NMR $\left(\mathrm{C}_{6} \mathrm{D}_{6}, 400.1 \mathrm{MHz}\right): \delta 7.21-7.09$ (overlapping $4 \times \mathrm{m}$, boryl and $\mathrm{NacNac} m$ - and $\left.p-\mathrm{C}_{6} \mathrm{H}_{3}{ }^{\mathrm{i}} \mathrm{Pr}_{2}\right), 5.91(2 \mathrm{H}, \mathrm{s}, \mathrm{NCH}), 4.93(1 \mathrm{H}, \mathrm{s}$, $\mathrm{MeC}(\mathrm{N}) \mathrm{CH}$ ), $3.58\left(2 \mathrm{H}\right.$, sept., ${ }^{3} \mathrm{~J}=6.9 \mathrm{~Hz}$, boryl $\left.\mathrm{CH}_{2} \mathrm{MeMe}\right), 3.31(3$ $\mathrm{H}$, overlapping $2 \times \mathrm{m}$, boryl $\mathrm{CH}_{b} \mathrm{MeMe}$ and $\left.\mathrm{NacNac} \mathrm{CHMeMe}\right), 3.09$ $\left(1 \mathrm{H}, \mathrm{m}, \mathrm{ScCH}_{2} \mathrm{CHMe}\right), 2.83(1 \mathrm{H}, \mathrm{s}, \mathrm{NH}), 2.58\left(1 \mathrm{H}, \mathrm{td},{ }^{2} J=13.5\right.$ $\left.\mathrm{Hz},{ }^{3} \mathrm{~J}=5.5 \mathrm{~Hz}, \underline{\mathrm{C}}_{2} \mathrm{NC}(\mathrm{Me})\right), 2.30\left(1 \mathrm{H}, \mathrm{td},{ }^{2} \mathrm{~J}=13.5 \mathrm{~Hz},{ }^{3} \mathrm{~J}=5.5\right.$ $\left.\mathrm{Hz}, \mathrm{CH}_{2} \mathrm{NMe}_{2}\right), 2.20\left(3 \mathrm{H}, \mathrm{s}, \mathrm{NMe}_{2}\right), 2.13\left(1 \mathrm{H}, \mathrm{dd},{ }^{2} J=13.5 \mathrm{~Hz},{ }^{3} J=\right.$ $\left.5.5 \mathrm{~Hz}, \mathrm{CH}_{2} \mathrm{NC}(\mathrm{Me})\right), 1.71(3 \mathrm{H}, \mathrm{s}, \mathrm{MeC}(\mathrm{N}) \mathrm{CH}), 1.64(3 \mathrm{H}, \mathrm{s}$, $\mathrm{MeC}(\mathrm{N}) \mathrm{CH}), 1.60\left(3 \mathrm{H}, \mathrm{s}, \mathrm{NMe}_{2}\right), 1.50\left(3 \mathrm{H}, \mathrm{d},{ }^{3} J=6.8 \mathrm{~Hz}, \mathrm{NacNac}\right.$ $\mathrm{CHMeMe}), 1.37(6 \mathrm{H}$, overlapping $2 \times \mathrm{d}$, NacNac $\mathrm{CHMeMe}$ and $\left.\mathrm{ScCH}_{2} \mathrm{CHMe}\right), 1.34\left(1 \mathrm{H}, \mathrm{m}, \mathrm{CH}_{2} \mathrm{NMe}_{2}\right), 1.27\left(12 \mathrm{H}, \mathrm{d},{ }^{3} J=6.9 \mathrm{~Hz}\right.$, boryl CHMeMe), $1.23\left(12 \mathrm{H}, \mathrm{d},{ }^{3} \mathrm{~J}=6.9 \mathrm{~Hz}\right.$, boryl CHMeMe $), 0.22(1$ $\mathrm{H}$, app. t, app. $\left.J=12.2 \mathrm{~Hz}, \mathrm{ScC}_{2}\right),-0.01\left(1 \mathrm{H}, \mathrm{dd},{ }^{2} J=12.2 \mathrm{~Hz},{ }^{3} J=\right.$ $3.3 \mathrm{~Hz})$ ppm. ${ }^{13} \mathrm{C}\left\{{ }^{1} \mathrm{H}\right\} \quad \mathrm{NMR}\left(\mathrm{C}_{6} \mathrm{D}_{6}, 100.6 \mathrm{MHz}\right): \delta 166.4$ $(\mathrm{Me} \underline{\mathrm{C}}(\mathrm{N}) \mathrm{CH}), 164.8(\mathrm{Me} \underline{\mathrm{C}}(\mathrm{N}) \mathrm{CH}), 147.8$ (boryl $o-\underline{\mathrm{C}}_{6} \mathrm{H}_{3}{ }^{\mathrm{i}} \mathrm{Pr}_{2}$ ), 147.6 ( NacNac o- ${ }_{6} \mathrm{H}_{3}{ }^{\mathrm{i}} \mathrm{Pr}_{2}$ ), 147.2 (boryl o- $\mathrm{C}_{6} \mathrm{H}_{3}{ }^{\mathrm{i}} \mathrm{Pr}_{2}$ ), 143.9 (NacNac $i$ - $\underline{\mathrm{C}}_{6} \mathrm{H}_{3}{ }^{\mathrm{i}} \mathrm{Pr}_{2}$ ), 141.9 (boryl $i-\underline{\mathrm{C}}_{6} \mathrm{H}_{3}{ }^{\mathrm{i}} \mathrm{Pr}_{2}$ ), 141.2 (boryl $i-\underline{C}_{6} \mathrm{H}_{3}{ }^{i} \mathrm{Pr}_{2}$ ), 126.8 (boryl $p-\mathrm{C}_{6} \mathrm{H}_{3}{ }^{\mathrm{i}} \mathrm{Pr}_{2}$ ), 125.5 (NacNac $p-\mathrm{C}_{6} \mathrm{H}_{3}{ }^{\mathrm{i}} \mathrm{Pr}_{2}$ ), 124.1 (boryl m$\underline{\mathrm{C}}_{6} \mathrm{H}_{3}{ }^{\mathrm{i}} \mathrm{Pr}_{2}$ ), 123.9 (NacNac $m-\underline{\mathrm{C}}_{6} \mathrm{H}_{3}{ }^{\mathrm{i}} \mathrm{Pr}_{2}$ ), 123.0 (boryl $m-\underline{\mathrm{C}}_{6} \mathrm{H}_{3}{ }^{\mathrm{i}} \mathrm{Pr}_{2}$ ), $122.0\left(\mathrm{NacNac} m-\underline{\mathrm{C}}_{6} \mathrm{H}_{3}{ }^{\mathrm{i}} \mathrm{Pr}_{2}\right), 117.8(\mathrm{NCH}), 98.5(\mathrm{MeC}(\mathrm{N}) \underline{\mathrm{C}} \mathrm{H}), 54.4$ $\left(\mathrm{CH}_{2} \mathrm{NMe}_{2}\right), 48.1\left(\mathrm{NMe}_{2}\right), 47.0\left(\mathrm{CH}_{2} \mathrm{NC}(\mathrm{Me})\right), 42.3\left(\mathrm{NMe}_{2}\right), 38.1$ ( $\mathrm{ScCH}_{2} \underline{\mathrm{CHMe}}$ ), $32.0\left(\mathrm{ScCH}_{2}\right), 29.0$ (boryl $\underline{\mathrm{C}}_{\mathrm{a}} \mathrm{HMeMe}$ ), 27.9 (boryl $\underline{\mathrm{C}}_{\mathrm{b}} \mathrm{HMeMe}$ ), 27.6 ( $\mathrm{NacNac} \mathrm{CHMeMe}$ ), 26.7 (boryl $\mathrm{CHMe}_{\mathrm{a}} \mathrm{Me}$ ), 26.1 (boryl CHMeMe ${ }_{a}$ and $\left.\mathrm{NacNac} \mathrm{CHMeMe}\right), 25.8\left(\mathrm{ScCH}_{2} \mathrm{CHMe}\right), 24.4$ (boryl CHMe $\mathrm{Me}_{\mathrm{b}}$ ), 23.6 ( $\left.\mathrm{NacNac} \mathrm{CHMeMe}\right), 23.2(\mathrm{MeC}(\mathrm{N}) \mathrm{CH})$, 22.5 (boryl $\mathrm{CHMe}_{b} \mathrm{Me}$ ), $22.3(\mathrm{MeC}(\mathrm{N}) \mathrm{CH})$ ppm. ${ }^{11} \mathrm{~B}\left\{{ }^{1} \mathrm{H}\right\}$ NMR $\left(\mathrm{C}_{6} \mathrm{D}_{6}, 128.4 \mathrm{MHz}\right): \delta 23.3 \mathrm{ppm}$. IR $\left(\mathrm{NaCl}\right.$ plates, Nujol mull, $\left.\mathrm{cm}^{-1}\right)$ : 3210 (w, N-H), 3059 (w), 2360 (w), 1922 (w), 1857 (w), 1793 (w), $1583(\mathrm{w}), 1530$ (s), 1360 (s) 1334 (s), $1319(\mathrm{~m}), 1273(\mathrm{~m}), 1229$ (w), $1176(\mathrm{~m}), 1136(\mathrm{~m}), 1115(\mathrm{w}), 1047(\mathrm{~m}), 970(\mathrm{~m}), 938(\mathrm{~m})$, $878(\mathrm{~m}), 846(\mathrm{w}), 805(\mathrm{~m}), 787(\mathrm{w}), 763(\mathrm{~s}), 748(\mathrm{~s}), 707(\mathrm{~m}), 650$ (m). Anal. Found (calcd) for $\mathrm{C}_{47} \mathrm{H}_{70} \mathrm{BN}_{6} \mathrm{Sc}$ : C, 72.71 (72.85); H, 9.21 (9.11); N, 10.95 (10.85)\%.

$\left(\mathrm{NacNac}{ }^{\mathrm{NMe}_{2}}\right) \mathrm{Sc}\left\{\mathrm{NHB}\left(\mathrm{NAr}{ }^{\prime} \mathrm{CH}\right)_{2}\right\}\left(\eta^{2}-\mathrm{NC}_{5} \mathrm{H}_{4}\right)$ (23). To a toluene solution $(8 \mathrm{~mL})$ of $\left(\mathrm{NacNac}^{\mathrm{NMe}_{2}}\right) \mathrm{Sc}(\mathrm{Me})\left\{\mathrm{NHB}\left(\mathrm{NAr}^{\prime} \mathrm{CH}\right)_{2}\right\} \quad(\mathbf{1 8}$, $0.197 \mathrm{~g}, 0.249 \mathrm{mmol})$ was added pyridine $(40 \mu \mathrm{L}, 0.498 \mathrm{mmol})$ at room temperature. The mixture was heated to $60^{\circ} \mathrm{C}$ and stirred for 16 $\mathrm{h}$, after which the volatiles were removed under reduced pressure, to afford 23 as an off-white solid, which was then dried in vacuo. Yield: $0.120 \mathrm{~g}(56 \%) .{ }^{1} \mathrm{H}$ NMR $\left(\mathrm{C}_{6} \mathrm{D}_{6}, 400.1 \mathrm{MHz}\right): \delta 7.32-7.26(5 \mathrm{H}$, overlapping $\mathrm{m}$, boryl and $\mathrm{NacNac} m$ - and $p-\mathrm{C}_{6} \mathrm{H}_{3}{ }^{\mathrm{i}} \mathrm{Pr}_{2}$ ), 7.11-7.04 (3 $\mathrm{H}$, overlapping $\mathrm{m}$, boryl and NacNac $m$ - and $\left.p-\mathrm{C}_{6} \mathrm{H}_{3}{ }^{i} \mathrm{Pr}_{2}\right), 6.89(2 \mathrm{H}$, overlapping $2 \times \mathrm{m}, 4-\mathrm{NC}_{5} \mathrm{H}_{4}$ and boryl $\left.m-\mathrm{C}_{6} \underline{\mathrm{H}}_{3}{ }^{\mathrm{i}} \mathrm{Pr}_{2}\right), 6.80(2 \mathrm{H}$, overlapping $2 \times \mathrm{m}, 3$ - and 6- $\left.\mathrm{NC}_{5} \mathrm{H}_{4}\right), 6.48\left(1 \mathrm{H}, \mathrm{m}, 5-\mathrm{NC}_{5} \mathrm{H}_{4}\right), 6.04(2$ $\mathrm{H}, \mathrm{s}, \mathrm{NCH}), 4.72(1 \mathrm{H}, \mathrm{s}, \mathrm{MeC}(\mathrm{N}) \mathrm{CH}), 3.72\left(2 \mathrm{H}\right.$, sept., ${ }^{3} J=6.9 \mathrm{~Hz}$, boryl $\left.\mathrm{C}_{\mathrm{a}} \mathrm{MeMe}\right), 3.50\left(2 \mathrm{H}\right.$, sept., ${ }^{3} \mathrm{~J}=6.9 \mathrm{~Hz}$, boryl $\left.\mathrm{C}_{\mathrm{b}} \mathrm{MeMe}\right)$, $3.21\left(1 \mathrm{H}, \mathrm{m}, \mathrm{C}_{2} \mathrm{NC}(\mathrm{Me})\right), 3.12(1 \mathrm{H}, \mathrm{s}, \mathrm{NH}), 2.96(2 \mathrm{H}$, overlapping $2 \times$ sept., $\mathrm{NacNac}$ C $\underline{\mathrm{HMeMe}}), 2.80\left(1 \mathrm{H}, \mathrm{m}, \mathrm{C}_{2} \mathrm{NC}-\right.$ 
(Me)), 2.30 (1 H, m, $\left.\underline{\mathrm{C}}_{2} \mathrm{NMe}_{2}\right), 2.06\left(1 \mathrm{H}, \mathrm{m}, \mathrm{CH}_{2} \mathrm{NMe}_{2}\right), 1.65$ (3 $\mathrm{H}, \mathrm{s}, \underline{\mathrm{MeC}}(\mathrm{N}) \mathrm{CH}), 1.56\left(6 \mathrm{H}, \mathrm{s}, \mathrm{NMe}_{2}\right), 1.55(3 \mathrm{H}, \mathrm{s}, \underline{\mathrm{MeC}}(\mathrm{N}) \mathrm{CH})$, $1.38\left(6 \mathrm{H}, \mathrm{d},{ }^{3} \mathrm{~J}=6.9 \mathrm{~Hz}\right.$, boryl $\left.\mathrm{CH}_{\mathrm{a}} \mathrm{MeMe}\right), 1.34(18 \mathrm{H}$, overlapping $3 \times \mathrm{d}$, boryl $\mathrm{CHMe}_{\mathrm{b}} \mathrm{Me}$ and CHMeMe $), 1.28\left(3 \mathrm{H}, \mathrm{d},{ }^{3} \mathrm{~J}=6.7 \mathrm{~Hz}\right.$, $\left.\mathrm{NacNac} \mathrm{CHMe}_{\underline{b}} \mathrm{Me}\right), 1.20\left(3 \mathrm{H}, \mathrm{d},{ }^{3} \mathrm{~J}=6.7 \mathrm{~Hz}, \mathrm{NacNac} \mathrm{CHMeMe}_{\mathrm{b}}\right)$, $1.10\left(3 \mathrm{H}, \mathrm{d},{ }^{3} J=6.7 \mathrm{~Hz}, \mathrm{NacNac} \mathrm{CHMe}_{\mathrm{a}} \mathrm{Me}\right), 0.53\left(3 \mathrm{H}, \mathrm{d},{ }^{3} J=6.7\right.$ $\mathrm{Hz}$, NacNac CHMeMe $)$ ppm. ${ }^{13} \mathrm{C}\left\{{ }^{1} \mathrm{H}\right\}$ NMR $\left(\mathrm{C}_{6} \mathrm{D}_{6}, 100.6 \mathrm{MHz}\right): \delta$ $217.2\left(2-\mathrm{NC}_{5} \mathrm{H}_{4}\right), 165.4(\mathrm{MeC}(\mathrm{N}) \mathrm{CH}), 165.3(\mathrm{Me} \underline{\mathrm{C}}(\mathrm{N}) \mathrm{CH}), 149.8$ (NacNac o- $\mathrm{C}_{6} \mathrm{H}_{3}{ }^{\mathrm{i}} \mathrm{Pr}_{2}$ ), 148.0 (boryl o- $\mathrm{C}_{6} \mathrm{H}_{3}{ }^{\mathrm{i}} \mathrm{Pr}_{2}$ ), 147.6 (boryl o$\underline{\mathrm{C}}_{6} \mathrm{H}_{3}{ }^{\mathrm{i}} \mathrm{Pr}_{2}$ ), $144.1\left(4-\mathrm{NC}_{5} \mathrm{H}_{4}\right.$ ), 142.7 (boryl $i-\underline{C}_{6} \mathrm{H}_{3}{ }^{1} \mathrm{Pr}_{2}$ ), 142.1 (boryl $i$ $\left.\mathrm{C}_{6} \mathrm{H}_{3}{ }^{\mathrm{i}} \mathrm{Pr}_{2}\right), 141.5\left(\mathrm{NacNac} i-\mathrm{C}_{6} \mathrm{H}_{3}{ }^{\mathrm{i}} \mathrm{Pr}_{2}\right), 132.0\left(6-\mathrm{NC}_{5} \mathrm{H}_{4}\right), 128.6$ (3$\left.\mathrm{NC}_{5} \mathrm{H}_{4}\right), 126.4$ (boryl $p-\underline{\mathrm{C}}_{6} \mathrm{H}_{3}{ }^{\mathrm{i}} \mathrm{Pr}_{2}$ ), 124.5 (NacNac $p-\underline{\mathrm{C}}_{6} \mathrm{H}_{3}{ }^{\mathrm{i}} \mathrm{Pr}_{2}$ ), 123.6 (boryl $m-\mathrm{C}_{6} \mathrm{H}_{3}{ }^{\mathrm{i}} \mathrm{Pr}_{2}$ ), 123.5 ( NacNac $m-\mathrm{C}_{6} \mathrm{H}_{3}{ }^{\mathrm{i}} \mathrm{Pr}_{2}$ ), 123.4 (boryl $m$ $\left.\mathrm{C}_{6} \mathrm{H}_{3}{ }^{\mathrm{i}} \mathrm{Pr}_{2}\right), 123.1$ (NacNac $\left.m-\underline{\mathrm{C}}_{6} \mathrm{H}_{3}{ }^{\mathrm{i}} \mathrm{Pr}_{2}\right), 120.7\left(5-\mathrm{NC}_{5} \mathrm{H}_{4}\right), 117.7$ $(\mathrm{NCH}), 99.5(\mathrm{MeC}(\mathrm{N}) \underline{\mathrm{CH}}), 60.4\left(\underline{\mathrm{CH}}_{2} \mathrm{NMe}_{2}\right), 47.2\left(\underline{\mathrm{CH}}_{2} \mathrm{NC}(\mathrm{Me})\right)$, $46.3\left(\mathrm{NMe}_{2}\right.$ ), 28.9 (boryl $\underline{\mathrm{C}}_{\mathrm{a}} \mathrm{HMeMe}$ ), 28.3 (boryl $\underline{\mathrm{C}}_{\mathrm{b}} \mathrm{HMeMe}$ ), 28.1 (NacNac $\left.\underline{C}_{a} \mathrm{HMeMe}\right), 28.0$ (NacNac $\underline{\mathrm{C}}_{\mathrm{b}} \mathrm{HMeMe}$ ), 26.1 (boryl $\mathrm{CHMeMe} \mathrm{Me}_{\mathrm{b}}$ ), 25.8 (boryl CHMe $\mathrm{Me}_{\mathrm{a}}$ ), 24.7 ( $\mathrm{NacNac} \mathrm{CHMeMe} \mathrm{Me}_{\mathrm{b}}$ and boryl $\left.\mathrm{CHMe}_{b} \mathrm{Me}\right), 24.5\left(\mathrm{NacNac} \mathrm{CHMeMe}_{2}\right), 24.4(\mathrm{MeC}(\mathrm{N}) \mathrm{CH}$ and $\mathrm{NacNac} \mathrm{CHMe}_{\mathrm{b}} \mathrm{Me}$ ), 23.2 (boryl $\mathrm{CHMe}$ ppm. ${ }^{11} \mathrm{~B}\left\{{ }^{1} \mathrm{H}\right\}$ NMR $\left(\mathrm{C}_{6} \mathrm{D}_{6}, 128.4 \mathrm{MHz}\right): \delta 23.5$ ppm. IR (NaCl plates, Nujol mull, $\mathrm{cm}^{-1}$ ): 3174 (br, w, N-H), 1921 (w), 1856 (w), $1790(\mathrm{w}), 1622(\mathrm{w}), 1583(\mathrm{~m}), 1544(\mathrm{~s}), 1521(\mathrm{~s}), 1337(\mathrm{~s}), 1320(\mathrm{~s})$, $1274(\mathrm{~m}), 1254(\mathrm{~s}), 1206(\mathrm{w}), 1180(\mathrm{~m}), 1132(\mathrm{w}), 1101(\mathrm{~m}), 1055$ (m), 998 (w), $961(\mathrm{w}), 937(\mathrm{~m}), 874(\mathrm{~m}), 846(\mathrm{w}), 805(\mathrm{~m}), 762(\mathrm{~s})$, $745(\mathrm{~s}), 704(\mathrm{w}), 671(\mathrm{w}), 653(\mathrm{~m}), 625(\mathrm{w})$. A satisfactory elemental analysis of $\mathbf{2 3}$ could not be obtained, due to high compound sensitivity and/or incomplete combustion, as described by Mindiola and coworkers for analogous compounds. ${ }^{11 \mathrm{~b}}$ The ${ }^{1} \mathrm{H}$ NMR spectrum of 23 is given in Figure S11.

$\left(\mathrm{NaCNac}^{\mathrm{NMe}_{2}}\right) \mathrm{Sc}\left\{\mathrm{NHB}\left(\mathrm{NAr}{ }^{\prime} \mathrm{CH}\right)_{2}\right\}$ (CCTol) (26). To a toluene solution $(8 \mathrm{~mL})$ of $\left(\mathrm{NacNac}^{\mathrm{NMe}_{2}}\right) \mathrm{Sc}(\mathrm{Me})\left\{\mathrm{NHB}\left(\mathrm{NAr}{ }^{\prime} \mathrm{CH}\right)_{2}\right\} \quad$ (18, $0.199 \mathrm{~g}, 0.251 \mathrm{mmol})$ was added HCCTol $(32 \mu \mathrm{L}, 0.251 \mathrm{mmol})$ at room temperature. The mixture was heated to $60{ }^{\circ} \mathrm{C}$ and stirred for 16 $\mathrm{h}$, after which the volatiles were removed under reduced pressure. The yellow waxy solid was washed with hexane $(2 \mathrm{~mL})$ to afford 26 as an off-white powder, which was then dried in vacuo. Yield: $0.112 \mathrm{~g}(50 \%)$. ${ }^{1} \mathrm{H}$ NMR $\left(\mathrm{C}_{6} \mathrm{D}_{6}, 400.1 \mathrm{MHz}\right): \delta 7.18$ (overlapping $4 \times \mathrm{m}$, boryl and NacNac $m$ - and $\left.p-\mathrm{C}_{6} \underline{\mathrm{H}}_{3}{ }^{\mathrm{i}} \mathrm{Pr}_{2}\right), 7.11\left(2 \mathrm{H}, \mathrm{d},{ }^{3} \mathrm{~J}=8.2 \mathrm{~Hz}, m-\mathrm{C}_{6} \underline{\mathrm{H}}_{4} \mathrm{Me}\right)$, $6.90\left(2 \mathrm{H}, \mathrm{d},{ }^{3} \mathrm{~J}=8.2 \mathrm{~Hz}, o-\mathrm{C}_{6} \underline{\mathrm{H}}_{4} \mathrm{Me}\right), 6.05(2 \mathrm{H}, \mathrm{s}, \mathrm{NCH}), 4.85(1 \mathrm{H}$, s, $\mathrm{MeC}(\mathrm{N}) \mathrm{C} \underline{\mathrm{H}}), 3.72\left(2 \mathrm{H}\right.$, sept., ${ }^{3} J=6.9 \mathrm{~Hz}$, boryl $\left.\mathrm{C}_{\mathrm{H}} \mathrm{MeMe}\right), 3.58$ $(1 \mathrm{H}, \mathrm{s}, \mathrm{NH}), 3.50\left(2 \mathrm{H}\right.$, sept., boryl $\left.\mathrm{CH}_{\mathrm{b}} \mathrm{MeMe}\right), 3.31\left(1 \mathrm{H}\right.$, sept., ${ }^{3} \mathrm{~J}=$ $\left.6.7 \mathrm{~Hz}, \mathrm{NacNac} \mathrm{CH}_{\mathrm{a}} \mathrm{MeMe}\right), 2.77\left(1 \mathrm{H}\right.$, sept., ${ }^{3} \mathrm{~J}=6.7 \mathrm{~Hz}, \mathrm{NacNac}$ $\left.\mathrm{CH}_{\mathrm{b}} \mathrm{MeMe}\right), 2.71\left(3 \mathrm{H}, \mathrm{s}, \mathrm{NMe}_{2}\right), 2.67(2 \mathrm{H}$, overlapping $2 \times \mathrm{m}$, $\mathrm{CH}_{2} \mathrm{NMe}_{2}$ and $\left.\mathrm{CH}_{2} \mathrm{NC}(\mathrm{Me})\right), 2.36\left(1 \mathrm{H}, \mathrm{m}, \mathrm{CH}_{2} \mathrm{NC}(\mathrm{Me})\right), 2.22$ (3 $\left.\mathrm{H}, \mathrm{s}, \mathrm{NMe}_{2}\right), 2.05\left(3 \mathrm{H}, \mathrm{s}, \mathrm{C}_{6} \mathrm{H}_{4} \mathrm{Me}\right), 1.79\left(1 \mathrm{H}, \mathrm{m}, \mathrm{CH}_{2} \mathrm{NMe}_{2}\right), 1.56$ $(3 \mathrm{H}, \mathrm{s}, \underline{\mathrm{MeC}}(\mathrm{N}) \mathrm{CH}), 1.54(3 \mathrm{H}, \mathrm{s}, \underline{\operatorname{MeC}}(\mathrm{N}) \mathrm{CH}), 1.52\left(6 \mathrm{H}, \mathrm{d},{ }^{3} \mathrm{~J}=\right.$ $6.9 \mathrm{~Hz}$, boryl $\left.\mathrm{CHMe}_{\mathrm{a}} \mathrm{Me}\right), 1.34(9 \mathrm{H}$, overlapping $2 \times \mathrm{d}$, NacNac $\mathrm{CHMe}_{b} \mathrm{Me}$ and boryl $\left.\mathrm{CHMe}{ }_{b} \mathrm{Me}\right), 1.28(9 \mathrm{H}$, overlapping $2 \times \mathrm{d}$, $\mathrm{NacNac} \mathrm{CHMe}{ }_{\mathrm{a}} \mathrm{Me}$ and boryl CHMeMe $\left.\mathrm{b}_{\mathrm{b}}\right), 1.23\left(6 \mathrm{H}, \mathrm{d},{ }^{3} \mathrm{~J}=6.9 \mathrm{~Hz}\right.$, boryl CHMeMe $\left.{ }_{a}\right), 1.09\left(3 \mathrm{H}, \mathrm{d},{ }^{3} J=6.7 \mathrm{~Hz}, \mathrm{NacNac} \mathrm{CHMeMe}_{\mathrm{b}}\right)$, $1.04\left(3 \mathrm{H}, d,{ }^{3} J=6.7 \mathrm{~Hz}, \mathrm{CHMeMe}{ }_{\mathrm{a}}\right)$ ppm. ${ }^{13} \mathrm{C}\left\{{ }^{1} \mathrm{H}\right\}$ NMR $\left(\mathrm{C}_{6} \mathrm{D}_{6}\right.$, $100.6 \mathrm{MHz}): \delta 166.6(\mathrm{MeC}(\mathrm{N}) \mathrm{CH}), 166.4(\mathrm{MeC}(\mathrm{N}) \mathrm{CH}), 155.4$ (ScCCTol), 147.7 (boryl o- $\underline{\mathrm{C}}_{6} \mathrm{H}_{3}{ }^{\mathrm{i}} \mathrm{Pr}_{2}$ ), 147.6 (boryl o- $\underline{\mathrm{C}}_{6} \mathrm{H}_{3}{ }^{\mathrm{i}} \operatorname{Pr}_{2}$ ), 146.9 ( NacNac o- $\underline{\mathrm{C}}_{6} \mathrm{H}_{3}{ }^{\mathrm{i}} \mathrm{Pr}_{2}$ ), 143.4 (NacNac $i-\mathrm{C}_{6} \mathrm{H}_{3}{ }^{\mathrm{i}} \mathrm{Pr}_{2}$ ), 142.4 (boryl $i$ $\left.\underline{\mathrm{C}}_{6} \mathrm{H}_{3}{ }^{\mathrm{i}} \mathrm{Pr}_{2}\right), 141.1$ (boryl $\left.i-\underline{-}_{6} \mathrm{H}_{3}{ }^{\mathrm{i}} \mathrm{Pr}_{2}\right), 138.7\left(i-\underline{\mathrm{C}}_{6} \mathrm{H}_{4} \mathrm{Me}\right), 135.1$ ( $p$ $\left.\mathrm{C}_{6} \mathrm{H}_{4} \mathrm{Me}\right), 132.1\left(m-\mathrm{C}_{6} \mathrm{H}_{4} \mathrm{Me}\right), 128.9\left(o-\mathrm{C}_{6} \mathrm{H}_{4} \mathrm{Me}\right), 126.8$ (boryl $p$ $\underline{\mathrm{C}}_{6} \mathrm{H}_{3}{ }^{\mathrm{i}} \mathrm{Pr}_{2}$ ), 125.8 (NacNac $p-\underline{\mathrm{C}}_{6} \mathrm{H}_{3}{ }^{\mathrm{i}} \mathrm{Pr}_{2}$ ), 124.6 (ScCETol), 123.9 (boryl $m-\mathrm{C}_{6} \mathrm{H}_{3}{ }^{\mathrm{i}} \mathrm{Pr}_{2}$ ), 123.5 (NacNac $m-\mathrm{C}_{6} \mathrm{H}_{3}{ }^{\mathrm{i}} \mathrm{Pr}_{2}$ ), $117.5(\mathrm{NCH}), 100.2$ $(\mathrm{MeC}(\mathrm{N}) \underline{\mathrm{CH}}), 58.5\left(\underline{\mathrm{CH}}_{2} \mathrm{NMe}_{2}\right), 48.8\left(\mathrm{NMe}_{2}\right), 46.9\left(\underline{\mathrm{CH}}_{2} \mathrm{NC}(\mathrm{Me})\right)$, $42.3\left(\mathrm{NMe}_{2}\right), 29.1$ (boryl $\left.\underline{\mathrm{C}}_{\mathrm{a}} \mathrm{HMeMe}\right), 28.6\left(\mathrm{NacNac} \mathrm{C}_{\mathrm{a}} \mathrm{HMeMe}\right)$, 28.4 ( NacNac $\underline{C}_{b} \mathrm{HMeMe}$ ), 28.2 (boryl $\underline{\mathrm{C}}_{b} \mathrm{HMeMe}$ ), 26.1 (boryl $\mathrm{CHMeMe}$ ), 26.0 (boryl $\mathrm{CHMeMe}_{\mathrm{a}}$ ), 24.9 ( $\mathrm{NacNac} \mathrm{CHMe}_{\mathrm{b}} \mathrm{Me}$ ), $24.7(\mathrm{MeC}(\mathrm{N}) \mathrm{CH}), 24.5\left(\mathrm{NacNac}_{\mathrm{CHMe}} \mathrm{Me}\right), 24.3$ (boryl

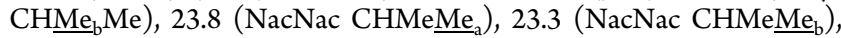
23.0 (boryl CHMe $\left.{ }_{a} \mathrm{Me}\right), 21.3\left(\mathrm{C}_{6} \mathrm{H}_{4} \mathrm{Me}\right)$ ppm. ${ }^{11} \mathrm{~B}\left\{{ }^{1} \mathrm{H}\right\} \mathrm{NMR}\left(\mathrm{C}_{6} \mathrm{D}_{6}\right.$, 128.4 MHz): $\delta 22.9 \mathrm{ppm}$. IR ( NaCl plates, Nujol mull, $\left.\mathrm{cm}^{-1}\right): 3195$ (w, N-H), $2074(\mathrm{w}), 1902(\mathrm{w}), 1793(\mathrm{w}), 1584(\mathrm{w}), 1541(\mathrm{~m}), 1525$ (s), $1505(\mathrm{~m}), 1415(\mathrm{~s}), 1359$ (s), 1339 (s), $1316(\mathrm{~m}), 1255(\mathrm{~m})$, $1199(\mathrm{~m}), 1178(\mathrm{~m}), 1134(\mathrm{w}), 1102(\mathrm{w}), 1054(\mathrm{~m}), 963(\mathrm{w}), 937$ (w), $879(\mathrm{w}), 847(\mathrm{w}), 819(\mathrm{~m}), 807(\mathrm{~m}), 764(\mathrm{~m}), 751(\mathrm{~s}), 708(\mathrm{w})$, $651(\mathrm{~m})$. Anal. Found (calcd) for $\mathrm{C}_{56} \mathrm{H}_{78} \mathrm{BN}_{6} \mathrm{Sc}$ : C, 72.16 (75.49); H, 9.00 (8.82); N, 9.33 (9.43)\%. Repeated attempts to obtain an elemental analysis with satisfactory $\% \mathrm{C}$ values failed, presumably due to incomplete combustion of the compound, as we have previously observed for certain scandium hydrocarbyl compounds. ${ }^{116}$ The ${ }^{1} \mathrm{H}$ NMR spectrum of $\mathbf{2 6}$ is given in Figure S13.

$\left(\mathrm{NacNac}^{\mathrm{NMe}_{2}}\right) \mathrm{Sc}\left\{\mathbf{N}\left\{\mathrm{B}\left(\mathrm{NAr}{ }^{\prime} \mathrm{CH}\right)_{2}\right\} \mathrm{C}(\mathrm{Me}) \mathrm{C}(\mathrm{Ph})\right\}$ (27). To a toluene solution $(8 \mathrm{~mL})$ of $\left(\mathrm{NacNac}^{\mathrm{NMe}_{2}}\right) \mathrm{Sc}(\mathrm{Me})\left\{\mathrm{NHB}\left(\mathrm{NAr}^{\prime} \mathrm{CH}\right)_{2}\right\} \quad$ (18, $0.197 \mathrm{~g}, 0.249 \mathrm{mmol})$ was added $\mathrm{MeCCPh}(31.5 \mu \mathrm{L}, 0.252 \mathrm{mmol})$ at room temperature. The mixture was heated to $60^{\circ} \mathrm{C}$ and stirred for 16 $\mathrm{h}$, after which the volatiles were removed under reduced pressure. The orange waxy solid was washed with hexane $(2 \times 2 \mathrm{~mL})$ to afford 27 as a yellow powder, which was then dried in vacuo. Yield: $0.106 \mathrm{~g}$ (48\%). Diffraction-quality crystals were grown from a benzene solution at room temperature. ${ }^{1} \mathrm{H}$ NMR $\left(\mathrm{C}_{6} \mathrm{D}_{6}, 400.1 \mathrm{MHz}\right): \delta$ 7.26-7.06 (overlapping $5 \times \mathrm{m}$, boryl and NacNac $m$ - and $p-\mathrm{C}_{6} \underline{\mathrm{H}}_{3}{ }_{3} \mathrm{Pr}_{2}$ and $m$ $\left.\mathrm{C}_{6} \mathrm{H}_{5}\right), 6.85\left(1 \mathrm{H}, \mathrm{t},{ }^{3} \mathrm{~J}=7.2 \mathrm{~Hz}, p-\mathrm{C}_{6} \mathrm{H}_{5}\right), 6.17(2 \mathrm{H}, \mathrm{s}, \mathrm{NCH}), 5.90(2$ $\left.\mathrm{H}, \mathrm{d},{ }^{3} \mathrm{~J}=7.2 \mathrm{~Hz}, o-\mathrm{C}_{6} \mathrm{H}_{5}\right), 4.89(1 \mathrm{H}, \mathrm{s}, \mathrm{MeC}(\mathrm{N}) \mathrm{CH}), 3.65(2 \mathrm{H}$, sept., ${ }^{3} \mathrm{~J}=6.9 \mathrm{~Hz}$, boryl $\left.\mathrm{C}_{\mathrm{H}} \mathrm{MeMe}\right), 3.48(2 \mathrm{H}$, sept., boryl $\mathrm{C}_{6} \mathrm{MeMe}$ ), 3.00 (1 H, sept., $\left.{ }^{3} \mathrm{~J}=6.7 \mathrm{~Hz}, \mathrm{NacNac} \underline{\mathrm{H}}_{\mathrm{a}} \mathrm{MeMe}\right), 2.93$ $\left(1 \mathrm{H}, \mathrm{m}, \mathrm{C}_{2} \mathrm{NC}(\mathrm{Me})\right), 2.70\left(1 \mathrm{H}, \mathrm{m}, \mathrm{C}_{2} \mathrm{NC}(\mathrm{Me})\right), 2.58(3 \mathrm{H}, \mathrm{s}$, $\mathrm{ScC}=\mathrm{CMe}), 2.44\left(1 \mathrm{H}\right.$, sept., $\left.{ }^{3} \mathrm{~J}=6.7 \mathrm{~Hz}, \mathrm{NacNac} \underline{\mathrm{CH}}_{\mathrm{b}} \mathrm{MeMe}\right), 1.81$ $\left(3 \mathrm{H}, \mathrm{s}, \mathrm{NMe}_{2}\right), 1.73(3 \mathrm{H}, \mathrm{s}, \mathrm{MeC}(\mathrm{N}) \mathrm{CH}), 1.64\left(3 \mathrm{H}, \mathrm{s}, \mathrm{NMe}_{2}\right), 1.61$ $(3 \mathrm{H}, \mathrm{s}, \mathrm{MeC}(\mathrm{N}) \mathrm{CH}), 1.51\left(1 \mathrm{H}, \mathrm{s}, \mathrm{CH}_{2} \mathrm{NMe}_{2}\right), 1.38(7 \mathrm{H}$, overlapping $\mathrm{m}$ and $\mathrm{d}$, boryl $\mathrm{CHMe}_{\mathrm{a}} \mathrm{Me}$ and $\left.\underline{\mathrm{C}}_{2} \mathrm{NMe}_{2}\right), 1.24(18 \mathrm{H}$, overlapping $3 \times \mathrm{d}$, boryl $\mathrm{CHMe}_{\mathrm{b}} \mathrm{Me}$ and $\left.\mathrm{CHMeMe}\right), 1.13\left(3 \mathrm{H}, \mathrm{d},{ }^{3} \mathrm{~J}=\right.$ $\left.6.7 \mathrm{~Hz}, \mathrm{NacNac} C \mathrm{CHe}_{\mathrm{a}} \mathrm{Me}\right), 1.10\left(3 \mathrm{H}, \mathrm{d},{ }^{3} \mathrm{~J}=6.7 \mathrm{~Hz}, \mathrm{NacNac}\right.$ $\left.\mathrm{CHMe}_{\mathrm{b}} \mathrm{Me}\right), 1.04\left(3 \mathrm{H}, \mathrm{d},{ }^{3} \mathrm{~J}=6.7 \mathrm{~Hz}, \mathrm{NacNac} \mathrm{CHMeMe} \mathrm{e}_{\mathrm{a}}\right), 0.42(3$ $\left.\mathrm{H}, \overline{\mathrm{d}},{ }^{3} \mathrm{~J}=6.7 \mathrm{~Hz}, \mathrm{NacNac} \mathrm{CHMeMe} \underline{\mathrm{b}}_{\mathrm{b}}\right) \mathrm{ppm} .{ }^{13} \mathrm{C}\left\{{ }^{1} \mathrm{H}\right\} \mathrm{NMR}\left(\mathrm{C}_{6} \mathrm{D}_{6}\right.$, $100.6 \mathrm{MHz}): \delta 172.9 \quad(\mathrm{Sc} \underline{\mathrm{C}}=\mathrm{CMe}), 166.8(\mathrm{Me} \underline{\mathrm{C}}(\mathrm{N}) \mathrm{CH}), 165.8$ $(\mathrm{Me} \underline{\mathrm{C}}(\mathrm{N}) \mathrm{CH}), 154.5(\mathrm{ScC}=\underline{\mathrm{CMe}}), 147.3$ (boryl $\left.o-\underline{\mathrm{C}}_{6} \mathrm{H}_{3}{ }^{\mathrm{i}} \mathrm{Pr}_{2}\right), 146.9$ (boryl o- $\underline{\mathrm{C}}_{6} \mathrm{H}_{3}{ }^{\mathrm{i}} \mathrm{Pr}_{2}$ ), 144.5 ( $\mathrm{NacNac} o-\underline{\mathrm{C}}_{6} \mathrm{H}_{3}{ }^{\mathrm{i}} \mathrm{Pr}_{2}$ ), 142.1 (boryl $i$ $\left.\underline{\mathrm{C}}_{6} \mathrm{H}_{3}{ }^{\mathrm{i}} \mathrm{Pr}_{2}\right), 141.7\left(\mathrm{NacNac} i-\underline{C}_{6} \mathrm{H}_{3}{ }^{\mathrm{i}} \mathrm{Pr}_{2}\right), 127.5\left(i-\mathrm{C}_{6} \mathrm{H}_{5}\right), 127.4(m-$ $\left.\mathrm{C}_{6} \mathrm{H}_{5}\right), 127.1\left(o-\mathrm{C}_{6} \mathrm{H}_{5}\right), 125.6\left(\mathrm{NacNac} p-\mathrm{C}_{6} \mathrm{H}_{3}{ }^{\mathrm{i}} \mathrm{Pr}_{2}\right), 125.2(\mathrm{NacNac}$ $m-\underline{C}_{6} \mathrm{H}_{3}{ }^{\mathrm{i}} \mathrm{Pr}_{2}$ ), 124.4 (boryl $p-\underline{\mathrm{C}}_{6} \mathrm{H}_{3}{ }^{\mathrm{i}} \mathrm{Pr}_{2}$ ), 123.7 (boryl $m-\underline{\mathrm{C}}_{6} \mathrm{H}_{3}{ }^{\mathrm{i}} \mathrm{Pr}_{2}$ ), $123.5\left(\mathrm{NacNac} m-\mathrm{C}_{6} \mathrm{H}_{3}{ }^{\mathrm{i}} \mathrm{Pr}_{2}\right), 120.3\left(p-\mathrm{C}_{6} \mathrm{H}_{5}\right), 119.1(\mathrm{NCH}), 100.0$ $(\mathrm{MeC}(\mathrm{N}) \underline{\mathrm{CH}}), 58.6\left(\mathrm{CH}_{2} \mathrm{NMe}_{2}\right), 48.5\left(\mathrm{NMe}_{2}\right), 47.0\left(\underline{\mathrm{CH}}_{2} \mathrm{NC}(\mathrm{Me})\right)$,

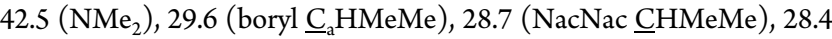
(boryl $\underline{\mathrm{C}}_{\mathrm{b}} \mathrm{HMeMe}$ ), 26.2 ( $\mathrm{NacNac} \mathrm{CHMe}_{\mathrm{b}} \mathrm{Me}$ ), 25.8 (boryl $\mathrm{CHMeMe}_{\mathrm{a}}$ and $\left.\mathrm{CHMe}_{b} \mathrm{Me}\right), 25.2(\mathrm{MeC}(\mathrm{N}) \mathrm{CH}), 24.9(\mathrm{NacNac}$ $\mathrm{CHMe}_{\mathrm{a}} \mathrm{Me}$ and $\mathrm{CHMeMe}$ ), 24.0 (boryl $\mathrm{CHMeMe}_{\mathrm{b}}$ ), 23.0 ( $\mathrm{MeC}$ (N)CH), 22.9 ( $\mathrm{NacNac} \mathrm{CHMeMe}_{\mathrm{b}}$ ), 22.7 (boryl $\mathrm{CHMe}_{2} \mathrm{Me}$ ), 21.8 $(\mathrm{ScC}=\mathrm{CMe}) \mathrm{ppm} .{ }^{11} \mathrm{~B}\left\{{ }^{1} \mathrm{H}\right\} \mathrm{NMR}\left(\mathrm{C}_{6} \mathrm{D}_{6}, 128.4 \mathrm{MHz}\right): \delta 24.6 \mathrm{ppm}$. IR ( $\mathrm{NaCl}$ plates, Nujol mull, cm ${ }^{-1}$ ): 1928 (w), 1862 (w), 1797 (w), $1580(\mathrm{~m}), 1548(\mathrm{~m}), 1524$ (s), 1407 (s), 1339 (s), 1315 (s), 1269 (m), $1244(\mathrm{~m}), 1203(\mathrm{~m}), 1181(\mathrm{w}), 1170(\mathrm{w}), 1119(\mathrm{w}), 1101(\mathrm{w})$, $1066(\mathrm{w}), 998(\mathrm{w}), 965(\mathrm{w}), 935(\mathrm{w}), 903(\mathrm{w}), 879(\mathrm{w}), 849(\mathrm{w}), 841$ $(\mathrm{w}), 818(\mathrm{~m}), 803(\mathrm{~m}), 766(\mathrm{~m}), 750(\mathrm{~m}), 700(\mathrm{~m}), 673(\mathrm{w})$. Anal. Found (calcd) for $\mathrm{C}_{56} \mathrm{H}_{78} \mathrm{BN}_{6} \mathrm{Sc}$ : C, 75.35 (75.49); H, 8.87 (8.82); N, $9.33(9.43) \%$.

\section{ASSOCIATED CONTENT}

\section{Supporting Information}

The Supporting Information is available free of charge on the ACS Publications website at DOI: 10.1021 /jacs.7b05405.

Details of starting materials, synthesis and characterization data for new compounds, kinetic experiments, and crystal structure determinations, including X-ray data collection and processing parameters (PDF)

Computed Cartesian coordinates of all of the molecules reported in this study (XYZ)

X-ray crystallographic data for 16, 17, 18, 21, and 27 (also deposited as CCDC 1548348-1548352) (CIF) 


\section{AUTHOR INFORMATION}

\section{Corresponding Authors}

*eric.clot@umontpellier.fr

*philip.mountford@chem.ox.ac.uk

\section{ORCID}

Eric Clot: 0000-0001-8332-5545

Philip Mountford: 0000-0001-9869-9902

Notes

The authors declare no competing financial interest.

\section{ACKNOWLEDGMENTS}

This work was funded by the EPSRC (grant reference EP/ L505031/1) and the University of Oxford Clarendon Fund and SCG Innovation Fund. We thank the University of Oxford's Advanced Research Computing facility for access to supercomputer and other resources, and Professors W. E. Piers and R. Anwander and Dr. D. Schädle for helpful discussions. This paper is dedicated to Professors R. G. Bergman and P. T. Wolczanski.

\section{REFERENCES}

(1) (a) Nugent, W. A.; Mayer, J. M. Metal-Ligand Multiple Bonds; Wiley-Interscience: New York, 1988. (b) Wigley, D. E. Prog. Inorg. Chem. 1994, 42, 239-482. (c) Cundari, T. R. Chem. Rev. 2000, 100, 807-818. (d) Giesbrecht, G. R.; Gordon, J. C. Dalton Trans. 2004, 2387-2393. (e) Dilworth, J. R. Coord. Chem. Rev. 2017, 330, 53-94. (f) Summerscales, O. T.; Gordon, J. C. RSC Adv. 2013, 3, 6682-6692.

(2) (a) Mountford, P. Chem. Commun. 1997, 2127-2134. (b) Gade, L. H.; Mountford, P. Coord. Chem. Rev. 2001, 216-217, 65-97. (c) Duncan, A. P.; Bergman, R. G. Chem. Rec. 2002, 2, 431-445.

(d) Hazari, N.; Mountford, P. Acc. Chem. Res. 2005, 38, 839-849.

(e) Odom, A. L. Dalton Trans. 2005, 225-233. (f) Mindiola, D. J. Angew. Chem., Int. Ed. 2008, 47, 1557-1559. (g) Gianetti, T. L.; La Pierre, H. S.; Arnold, J. Eur. J. Inorg. Chem. 2013, 2013, 3771-3783. (h) Lorber, C. Coord. Chem. Rev. 2016, 308, 76-96.

(3) (a) Schrock, R. R. Tetrahedron 1999, 55, 8141-8153. (b) Schrock, R. R. Hoveyda, A. H. Angew. Chem., Int. Ed. 2003, 42, $4592-4633$.

(4) (a) Schrock, R. R. Acc. Chem. Res. 1990, 23, 158-165. (b) Bolton, P. D.; Mountford, P. Adv. Synth. Catal. 2005, 347, 355-366.

(5) Lu, E.; Li, Y.; Chen, Y. Chem. Commun. 2010, 46, 4469-4471.

(6) Beetstra, D. J.; Meetsma, A.; Hessen, B.; Teuben, J. H. Organometallics 2003, 22, 4372-4374.

(7) Chu, T.; Piers, W. E.; Dutton, J. L.; Parvez, M. Organometallics 2013, 32, 1159-1165.

(8) Rong, W.; Cheng, J.; Mou, Z.; Xie, H.; Cui, D. Organometallics 2013, 32, 5523-5529.

(9) Schädle, D.; Meermann-Zimmermann, M.; Schädle, C.; MaichleMössmer, C.; Anwander, R. Eur. J. Inorg. Chem. 2015, 2015, 13341339.

(10) Solola, L. A.; Zabula, A. V.; Dorfner, W. L.; Manor, B. C.; Carroll, P. J.; Schelter, E. J. J. Am. Chem. Soc. 2016, 138, 6928-6931.

(11) (a) Scott, J.; Basuli, F.; Fout, A. R.; Huffman, J. C.; Mindiola, D. J. Angew. Chem., Int. Ed. 2008, 47, 8502-8505. (b) Wicker, B. F.; Fan, H.; Hickey, A. K.; Crestani, M. G.; Scott, J.; Pink, M.; Mindiola, D. J. J. Am. Chem. Soc. 2012, 134, 20081-20096.

(12) Wicker, B. F.; Scott, J.; Fout, A. R.; Pink, M.; Mindiola, D. J. Organometallics 2011, 30, 2453-2456.

(13) Lu, E.; Chu, J.; Chen, Y.; Borzov, M. V.; Li, G. Chem. Commun. 2011, 47, 743-745.

(14) (a) Boyd, C. L.; Clot, E.; Guiducci, A. E.; Mountford, P. Organometallics 2005, 24, 2347-2367. (b) Green, J. C.; Green, M. L. H.; James, J. T.; Konidaris, P. C.; Maunder, G. H.; Mountford, P. J. Chem. Soc., Chem. Commun. 1992, 1361-1365. (c) Selby, J. D.; Manley, C. D.; Feliz, M.; Schwarz, A. D.; Clot, E.; Mountford, P. Chem. Commun. 2007, 4937-4939. (d) Saleh, L. M. A.; Hassomal
Birjkumar, K.; Protchenko, A. V.; Schwarz, A. D.; Aldridge, S.; Jones, C.; Kaltsoyannis, N.; Mountford, P. J. Am. Chem. Soc. 2011, 133, 3836-3839.

(15) (a) Thompson, R.; Chen, C.-H.; Pink, M.; Wu, G.; Mindiola, D. J. J. Am. Chem. Soc. 2014, 136, 8197-8200. (b) Grant, L. N.; Pinter, B.; Kurogi, T.; Carroll, M. E.; Wu, G.; Manor, B. C.; Carroll, P. J.; Mindiola, D. J. Chem. Sci. 2017, 8, 1209-1224.

(16) Stevenson, L. C.; Mellino, S.; Clot, E.; Mountford, P. J. Am. Chem. Soc. 2015, 137, 10140-10143.

(17) Danopoulos, A. A.; Redshaw, C.; Vaniche, A.; WIlkinson, G.; Hussain-Bates, B.; Hursthouse, M. B. Polyhedron 1993, 12, 10611071.

(18) Weber, K.; Korn, K.; Schorm, A.; Kipke, J.; Lemke, M.; Khvorost, A.; Harms, K.; Sundermeyer, J. Z. Anorg. Allg. Chem. 2003, 629, 744-754.

(19) Fryzuk, M. D.; MacKay, B. A.; Johnson, S. A.; Patrick, B. O. Angew. Chem., Int. Ed. 2002, 41, 3709-3712.

(20) (a) Bettinger, H. F. J. Am. Chem. Soc. 2006, 128, 2534-2535. (b) Bettinger, H. F.; Bornemann, H. J. Am. Chem. Soc. 2006, 128, $11128-11134$.

(21) Pieper, W.; Schmitz, D.; Paetzold, P. Chem. Ber. 1981, 114, $3801-3812$.

(22) (a) Bettinger, H. F. Inorg. Chem. 2007, 46, 5188-5195. (b) Bettinger, H. F.; Filthaus, M.; Bornemann, H.; Oppel, I. M. Angew. Chem., Int. Ed. 2008, 47, 4744-4747. (c) Bettinger, H. F.; Filthaus, M.; Neuhaus, P. Chem. Commun. 2009, 2186-2188. (d) Filthaus, M.; Schwertmann, L.; Neuhaus, P.; Seidel, R. W.; Oppel, I. M.; Bettinger, H. F. Organometallics 2012, 31, 3894-3903. (e) Müller, M.; MaichleMössmer, C.; Bettinger, H. F. Chem. Commun. 2013, 49, 1177311775 .

(23) Hadlington, T. J.; Abdalla, J. A. B.; Tirfoin, R; Aldridge, S.; Jones, C. Chem. Commun. 2016, 52, 1717-1720.

(24) The parameter $\tau$ was defined by Addison et al. as $(A-B) / 60$, where $A$ and $B$ are the two greatest $\mathrm{L}-\mathrm{M}-\mathrm{L}$ angles in the complex. For an ideal square-based pyramid, $\tau=0$, and for an ideal trigonal bipyramid, $\tau=1$. See: Addison, A. W.; Rao, T. N.; Reedijk, J.; van Rijn, J.; Verschoor, G. C. J. Chem. Soc., Dalton Trans. 1984, 1349-1356.

(25) Chu, J.; Han, X.; Kefalidis, C. E.; Zhou, J.; Maron, L.; Leng, X.; Chen, Y. J. Am. Chem. Soc. 2014, 136, 10894-10897.

(26) (a) Mountford, P.; Ward, B. D. Chem. Commun. 2003, 17971803. (b) Knight, L. K.; Piers, W. E.; Fleurat-Lessard, P.; Parvez, M.; McDonald, R. Organometallics 2004, 23, 2087-2094.

(27) Brotzel, F.; Kempf, B.; Singer, T.; Zipse, H.; Mayr, H. Chem. Eur. J. 2007, 13, 336-345.

(28) (a) Bennett, J. L.; Wolczanski, P. T. J. Am. Chem. Soc. 1997, 119, 10696-10719. (b) Cummins, C. C.; Baxter, S. M.; Wolczanski, P. T. J. Am. Chem. Soc. 1988, 110, 8731-8733. (c) Cummins, C. C.; Schaller, C. P.; Van Duyne, G. D.; Wolczanski, P. T.; Chan, A. W. E.; Hoffmann, R. J. Am. Chem. Soc. 1991, 113, 2985-2994. (d) Schaller, C. P.; Cummins, C. C.; Wolczanski, P. T. J. Am. Chem. Soc. 1996, 118, 591-611. (e) Slaughter, L. M.; Wolczanski, P. T.; Klinckman, T. R.; Cundari, T. R. J. Am. Chem. Soc. 2000, 122, 7953-7975. (f) Manna, K.; Ellern, A.; Sadow, A. D. Chem. Commun. 2010, 46, 339-341. (g) Walsh, P. J.; Hollander, F. J.; Bergman, R. G. J. Am. Chem. Soc. 1988, 110, 8729-8731. (h) Gómez-Gallego, M.; Sierra, M. A. Chem. Rev. 2011, 111, 4857-4963. (i) Balcells, D.; Clot, E.; Eisenstein, O. Chem. Rev. 2010, 110, 749-823. (j) Webb, J. R.; Burgess, S. A.; Cundari, T. R.; Gunnoe, T. B. Dalton Trans. 2013, 42, 16646-16665. (k) Hoyt, H. M.; Bergman, R. G. Angew. Chem., Int. Ed. 2007, 46, 5580-5582.

(29) (a) Lowry, T. H.; Richardson, K. S. Mechanism and Theory in Organic Chemistry; Harper and Row: New York, 1987. (b) Carpenter, B. K. Determination of Reaction Mechanisms; Wiley-Interscience: New York, 1984.

(30) (a) Bolton, P. D.; Clot, E.; Adams, N.; Dubberley, S. R.; Cowley, A. R.; Mountford, P. Organometallics 2006, 25, 2806-2825. (b) Guram, A. S.; Jordan, R. F. Organometallics 1991, 10, 34703479. (c) Jordan, R. F.; Guram, A. S. Organometallics 1990, 9, 21162123. (d) Deelman, B.-J.; Stevels, W. M.; Teuben, J. H.; Lakin, M. T.; 
Spek, A. L. Organometallics 1994, 13, 3881-3891. (e) Den Haan, K. H.; Wielstra, Y.; Teuben, J. H. Organometallics 1987, 6, 2053-2060.

(31) Weinhold, F.; Landis, C. R. Valency and Bonding: A Natural Bond Orbital Donor-Acceptor Perspective; Cambridge University Press: Cambridge, 2005.

(32) Bader, R. F. W. Atoms in Molecules: A Quantum Theory; Oxford University Press: Oxford, 1990.

(33) (a) Bolton, P. D.; Feliz, M.; Cowley, A. H.; Clot, E.; Mountford, P. Organometallics 2008, 27, 6096-6110. (b) Feliz, M.; Bolton, P. D.; Clot, E.; Mountford, P. Organometallics 2008, 27, 6111-6122.

(34) Schofield, A. D.; Nova, A.; Selby, J. D.; Manley, C. D.; Schwarz, A. D.; Clot, E.; Mountford, P. J. Am. Chem. Soc. 2010, 132, 1048410497.

(35) Schofield, A. D.; Nova, A.; Selby, J. D.; Schwarz, A. D.; Clot, E.; Mountford, P. Chem. - Eur. J. 2011, 17, 265-285.

(36) Pangborn, A. B.; Giardello, M. A.; Grubbs, R. H.; Rosen, R. K.; Timmers, F. J. Organometallics 1996, 15, 1518-1520. 